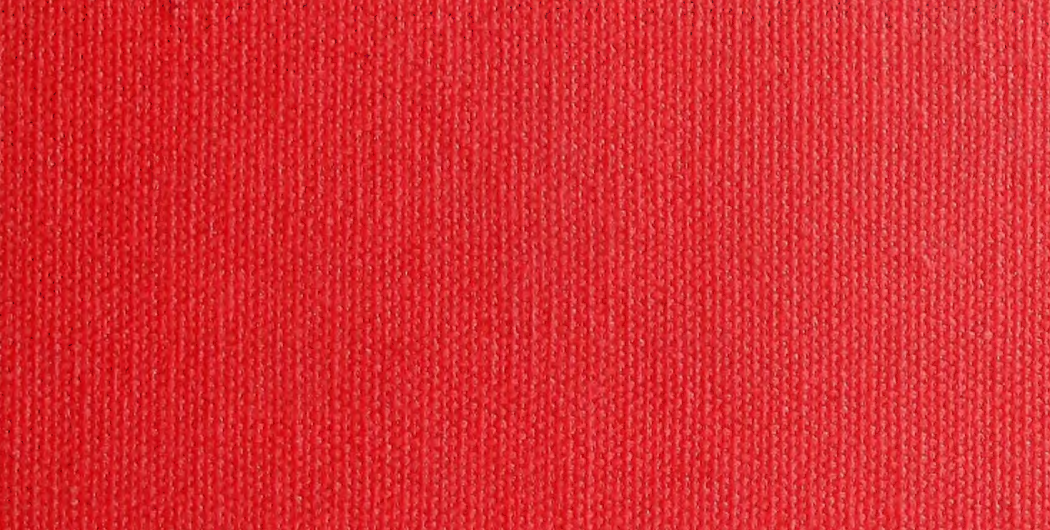

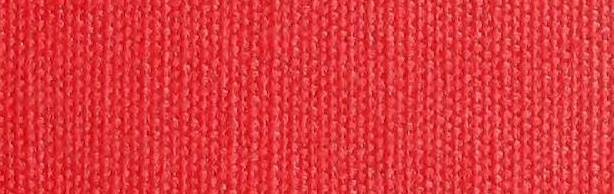
7.m. H. H.

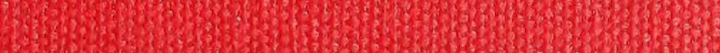

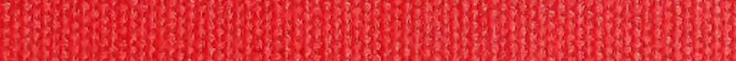
H. H.

W

M.

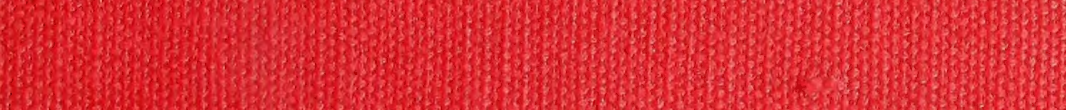
W.

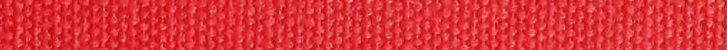

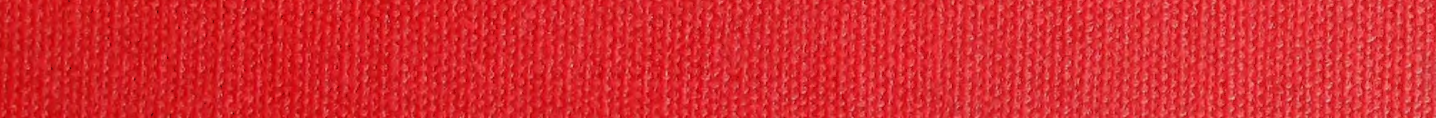
3.7. 16.

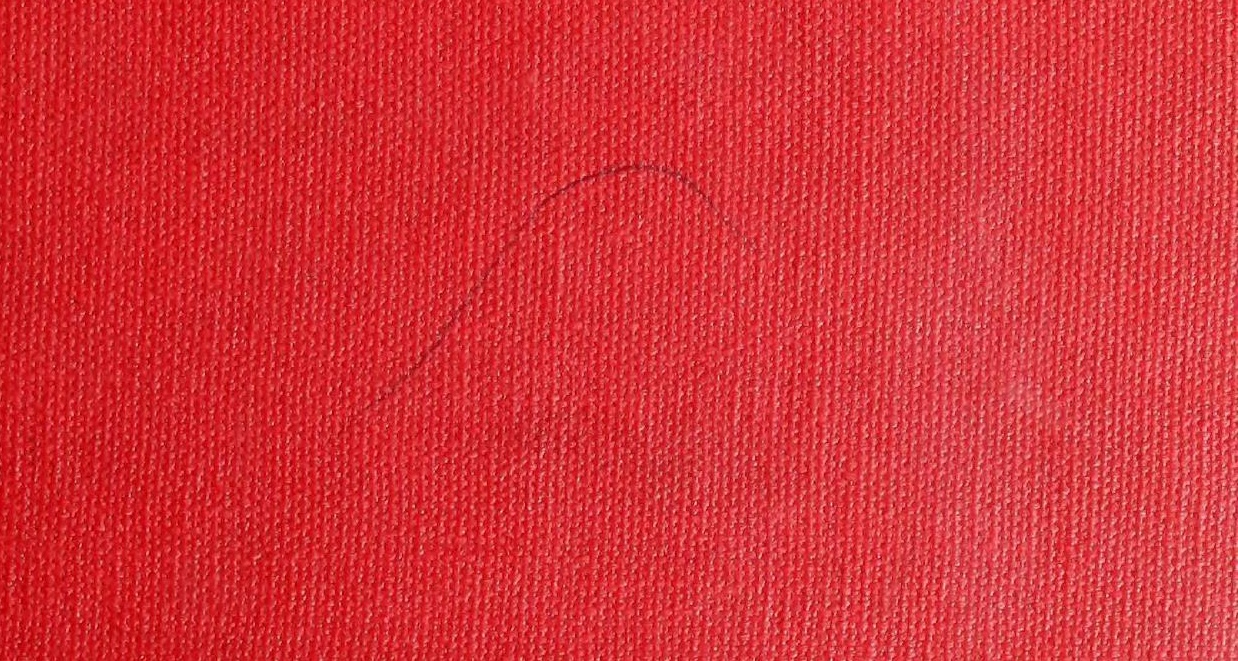





\section{Historic, archived document}

Do not assume content reflects current scientific knowledge, policies, or practices. 

$\frac{1}{20} 84 \mathrm{NT}$

MARKI RES. REP H T6S

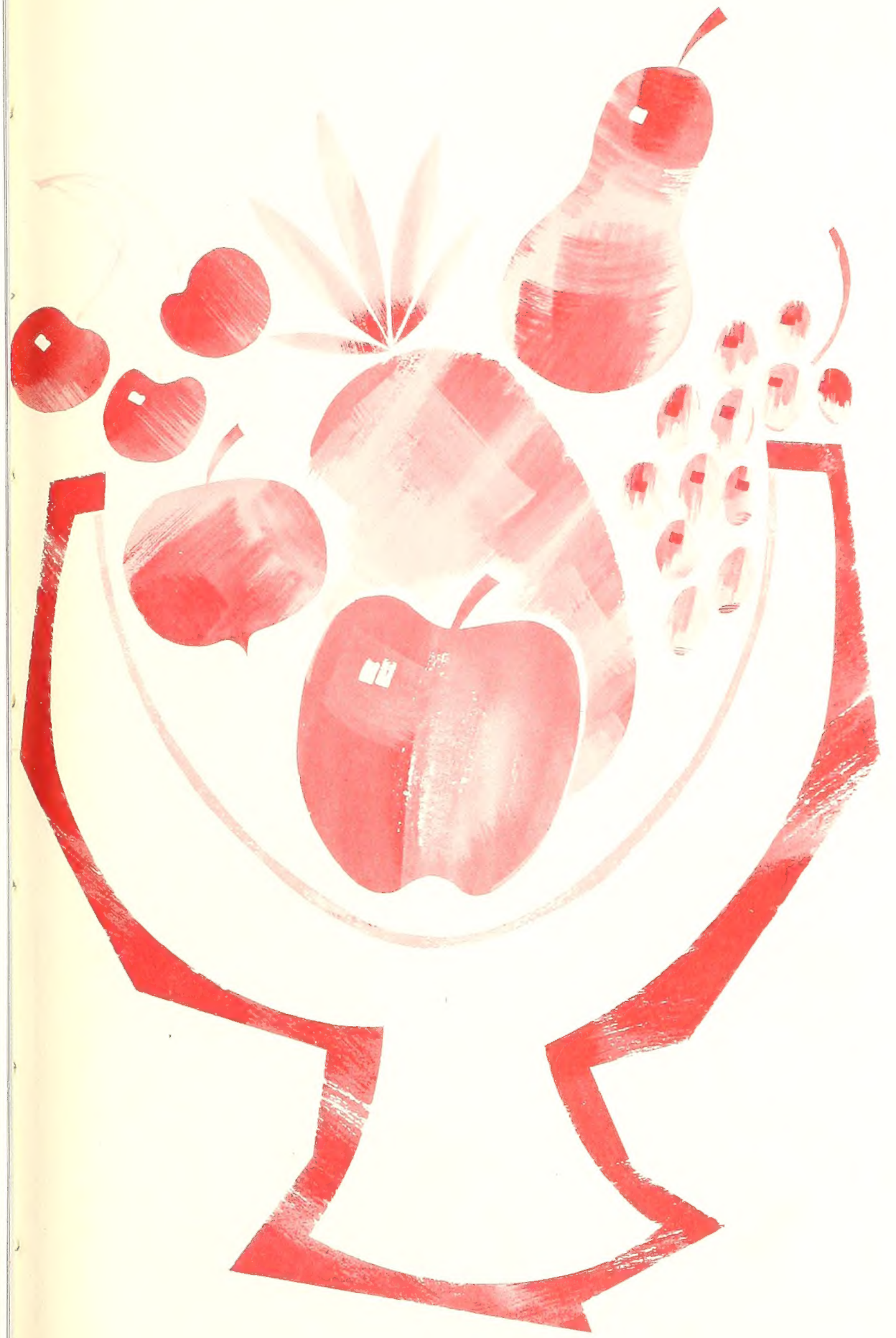

Homemakers'

Use of and

Opinions About

Selected Fruits

and Fruit

Products

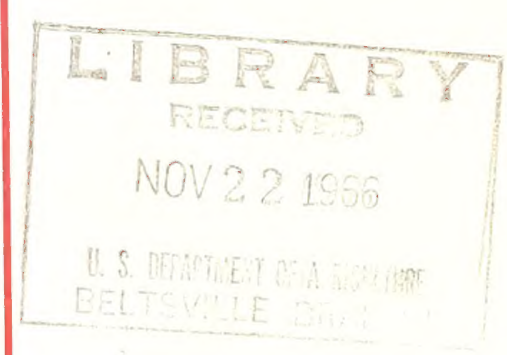

U.S. DEPARTMENT OF AGRICULTURE - STATISTICAL REPORTING SERVICE• MARKETING RESEARCH REPORT NO. 765 



\section{HIGHLIGHTS}

Nearly every household in the United States had purchased some fresh fruit in the past 12 months, according to the testimony of homemakers interviewed in a nationwide survey. A variety of fruits was used in the majority of these homes--better than half of the homemakers indicated that in the preceding year they had purchased 7 of the 11 fresh fruits covered in the questionnaire.

Nonpurchasers of the specific fresh fruits gave a variety of reasons for not buying these fruits. However, many of the reasons given did not indicate an actual dislike of the fruit itself. For example, nonpurchasers of apples, grapes, peaches, pears, and plums or fresh prunes cited "have own trees, friends and relative supply them" as reasons for not buying them. However, a large proportion of nonpurchasers of nectarines stated that they were "unfamiliar with the fruit." Apricots and cherries were not purchased because homemakers were "unable to obtain the fruit," while nearly half of those who had not purchased pineapple said that they had not done so because "it was difficult to prepare." Many pineapple users also mentioned this disadvantage.

Most homemakers (75 percent) generally like to buy unpackaged or 100 se fresh fruit, although 10 percent of this group said that there were some specific fruits they prefer packaged. "You get no spoiled or bruised fruit," "you can get the number you want," and "you can choose the one you want" were the main reasons given for preferring to buy fruit loose.

Homemakers were asked to select from a list of both positive and negative statements those they felt were especially true about six specific fresh fruits--apples, pears, bananas, grapes, peaches, and plums or fresh prunes. While homemakers generally selected the same positive statements for all the fruits, the frequency with which they were mentioned varied according to each fruit's special appeal to the consumer. "Good for health," and "good for snacks or packed lunches," were selected most often for most of the fruits. However, more than a third as many selected these reasons for apples (91 and 93 percent) as did for plums or fresh prunes (66 and 51 percent). "Can be used in many ways" was selected by more than twice as many homemakers for apples ( 86 percent) as for plums or fresh prunes (20 percent). Negative statements, on the other hand, were generally selected less frequently but with proportionately wider variation in frequency. "Messy to eat" was cited by better than 4 in 10 (43 percent) of the homemakers for peaches, while only 1 percent mentioned it for apples.

When they last purchased fruit, roughly half of the homemakers had a specific fruit in mind before they went to the store. Better than a fourth had planned to buy some fruit but decided on the specific fruit in the store; almost one-sixth did not have fruit in mind at all but decided to purchase some while in the store.

When asked what they thought could be done by the store manager to increase the purchase of fresh fruits, homemakers felt "high-quality fruit" and "attractive displays" would be the most important influences.

\section{FRESH APPLES}

The use of fresh apples in the home is almost universal, with better than 9 in 10 homemakers indicating they had purchased them in the last year. Fresh apples were purchased most often in the supermarkets (as defined by the respondent), followed by the grocery stores; however, the majority of homemakers said they bought them at more than one outlet. 


\section{PREFACE}

This report presents information on American homemakers' use of and attitudes toward selected fresh and processed fruits.

The study reported was conducted by the Special Surveys Branch, Standards and Research Division, Statistical Reporting Service. It is part of a broad program which will help agricultural industries strengthen their market position and give consumers an opportunity to evaluate the products available to them.

The study was conducted under the general direction of Trienah Meyers and Margaret Weidenhamer, and was planned by Elizabeth Watters. Subject-matter specialists in the U.S. Department of Agriculture and industry advisors gave technical advice during the development of the study. Industry advisors were the United Fresh Fruit and Vegeta'sle Association; National Peach Council; International Apple Association; National Apple Institute; and the California Grape and Tree Fruit League.

Crossley, S-D Surveys, Inc., New York City, under contract with the U.S. Department of Agriculture, designed the sample, developed the questionnaire, conducted the survey, and prepared a draft of the report.

A preliminary release (SRS-6--Homemakers' Use of and Opinions About Selected Fruits and Fruit Products) was published in May 1965.

\section{CONTENTS}

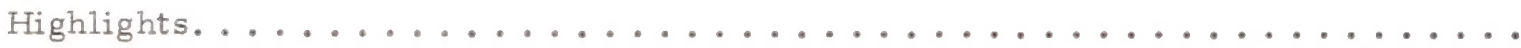

Introduction

Fresh noncitrus fruit

Use of fresh noncitrus fruits

Packaging of fruit

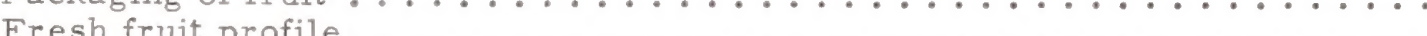

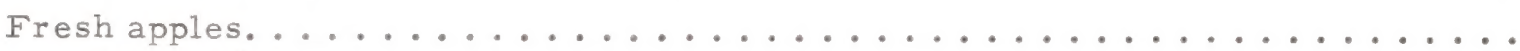

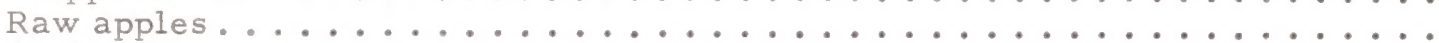

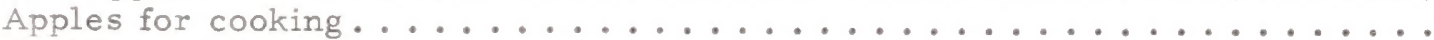

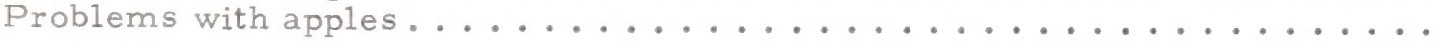

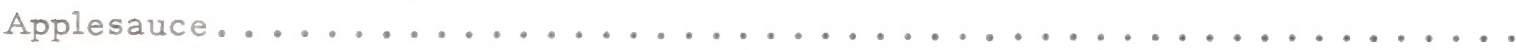

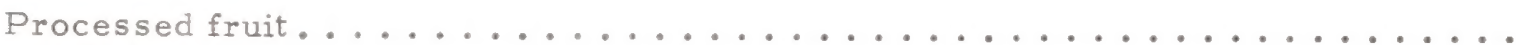

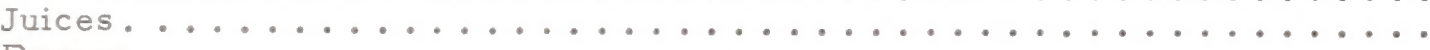

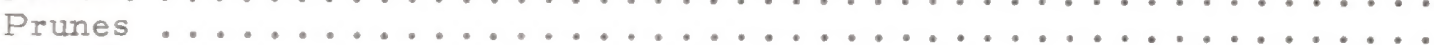

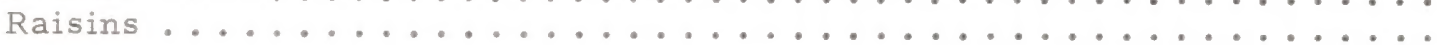

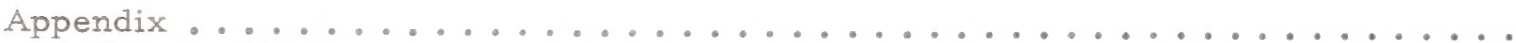

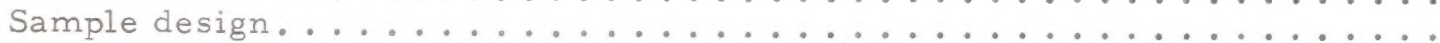

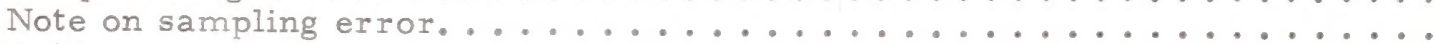

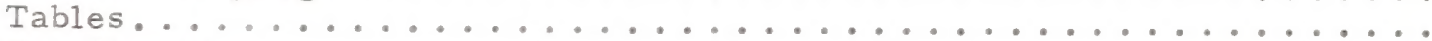

Questionnaire 
Nearly all homemakers who used fresh apples said they were eaten "out of hand," with better than half also using apples in salads. They were eaten either as daytime or evening snacks in 77 percent of the households; 39 percent of the homemakers reported that apples were carried in a "packed lunch" by family members.

When looking for fresh apples for eating raw, most homemakers wanted apples that were red, juicy, unblemished, not bruised, of medium size, firm but not hard, sweet, and of the Delicious variety.

Better than 8 homemakers in 10 said they had used fresh apples for cooking or baking in the preceding year. Those who had not used them gave as their reasons "prefer raw apples," "no time to bake," or "it is not worth the effort." Apple pies, baked apples, and applesauce were cited most often as uses of apples in cooking or baking.

About 6 in 10 of the respondents who reported using fresh apples for cooking or baking said that they used less than half of all the apples they purchased in this manner. The level of apple purchases seemingly was not related to the proportion used for cooking or baking. About 60 percent of the high and low purchasers of apples used less than half of the fresh apples they purchased in cooking or baking.

When choosing fresh apples for cooking or baking the homemaker wanted apples that were juicy, firm but not hard, tart, of medium size, and without blemishes or bruises. Color, while important, was not as important in a cooking apple as in one that was to be eaten raw. Preference for a certain variety of cooking apple seemed to vary by region, with no one variety an overall favorite.

Homemakers who mentioned that they had difficulty in finding good fresh apples were in the minority (14 percent). Most of those who did so, said they were difficult to find in the spring and summer. About twice as many homemakers (28 percent), however, had been disappointed in apples they had purchased in the past year. They were disappointed mainly with the texture or taste of the apples.

\section{APPLESAUCE}

Most of the homemakers said they had used applesauce in some form in the past year--36 percent had used both processed and homemade; almost the same proportion reported the use of processed only, while 14 percent had used homemade applesauce only. When the users of processed applesauce were asked which they preferred, nearly half indicated that they preferred the homemade variety mainly because of taste--either it "could be flavored to one's own taste," "had a better taste" generally, or "had a fresh taste." Those who said they preferred the processed (about a third) cited its convenience.

According to the majority of all the homemakers interviewed, "good applesauce" should be yellow, sweet tasting, smooth, and of medium thickness.

\section{PROCESSED FRUIT}

Homemakers were questioned about their use of nine canned fruits (pineapple, peaches, pears, apricots, sweet cherries, apples, plums or prunes, sour cherries, fruit cocktail or salad) in the last year. Between 32 and 86 percent indicated the use of each of these nine canned products. Only 3 percent said they had not purchased any of these canned products during that time.

Except for pineapple, the incidence of purchase of each of these fruits was higher among homemakers who had bought the same fresh fruit in the past year.

When asked which of four fruit juices (grape, pineapple, prune, and apple) they had purchased, from 38 to 63 percent of the homemakers reported using these juices in the past year. Only 13 percent indicated they had not purchased any of them. 


\section{PRUNES}

A large proportion of the respondents indicated that they had used prunes in some form (canned, dried or prune juice) in the last year. Dried prunes had been used by 59 percent of the homemakers, about half of whom had served them at least once a month.

A variety of reasons were given for the use of prunes. They were used mainly as a laxative or because they were healthy or nutritious.

\section{RAISINS}

The proportion of homemakers who used raisins in the home had not changed since 1957. In both surveys, 83 percent of the American homemakers reported using raisins; however, they were used less frequently by homemakers in the current survey. 


\title{
HOMEMAKERS' USE OF AND OPINIONS ABOUT SELECTED FRUITS AND FRUIT PRODUCTS
}

\author{
By
}

\author{
L. Yvonne Clayton, Study Director \\ Standards and Research Division \\ Statistical Reporting Service
}

\section{INTRODUCTION}

Per capita consumption of fresh noncitrus fruits has declined in the past 20 years, but consumption of processed noncitrus fruit during this same period increased considerably. To understand the noncitrus market better, the industry needs up-to-date information on how each product appeals to the consumer and what aspects the consumer reacts to negatively.

To provide these data, the U.S. Department of Agriculture conducted a nationwide survey of consumers' attitudes. Such information is an important aid in maintaining or increasing markets for, and consumers' satisfaction with, agricultural products.

Data were obtained in personal interviews with a national probability sample of homemakers, chosen as representative of households throughout the Nation. The homemaker is defined as the person with primary responsibility for purchasing and preparing food for the household. In most households this person is a woman, but men qualified as respondents in about 5 percent of the 2,454 sample households.

Interviewing was done from mid-November 1963 to mid-January 1964. Interviews required, on the average, about an hour.

\section{Limitations of the Data}

In interpreting the results of this study, as in all studies involving sampling, allowance must be made for error that might result from interviewing a sample and not the whole population. Sampling errors are discussed in the appendix. In general, figures based on the responses of all the homemakers interviewed may be assumed to be within 3 percentage points of the figures that would have been obtained from a census conducted under the same circumstances.

As in all studies, the figures are also subject to errors of response and of reporting. For example, some homemakers may have erred in reporting from memory on whether or not they had used certain products, the amount they had used, and the frequency with which they had used them during the past year.

It should be taken into consideration that when a homemaker says she uses a product two or three times a week she is describing what she considers to be her general practice. However, occasionally she may omit a week because the price is too high, because the item is not available, because the family is away, or for some other reason. Therefore, in any given week the proportion of homemakers using a product will undoubtedly be smaller than the proportion who say they use it once a week or more. 


\section{FRESH NONCITRUS FRUIT}

\section{USE OF FRESH NONCITRUS FRUITS}

Nearly every household in the United States used some fresh noncitrus fruit in the 12 months preceding the study. Homemakers were asked general questions on their purchase and use of 11 specific fresh fruits and more specific questions about some of them. Those respondents who had not purchased the specific fruits in the preceding 12 months were then questioned about their use of them in recent years. As shown below, better than half of the respondents said that they had purchased bananas, apples, oranges (included to permit comparison), grapes, peaches, pears, and plums or fresh prunes, and over a third reported the purchase of cherries and nectarines. Nonusers were questioned about their purchase of these fruits in recent years. From 10 to 17 percent of the homemakers said they had purchased cherries, nectarines, pineapple, and apricots in recent years.

Homemakers who had purchased fresh fruit:

$\underline{\text { Fruit }}$

In the past 12 months

Percent

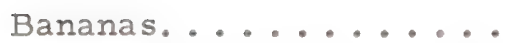

Apples............

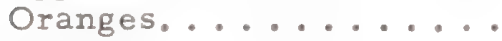

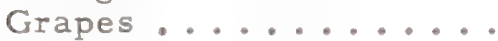

Peaches............

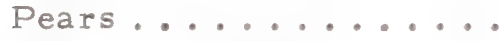

Plums or prunes.......

Cherries (sweet)......

Nectarines..........

Pineapple..........

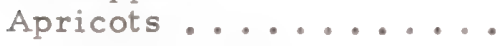

Not in the past 12 months but in recent years ${ }^{1}$

Percent

1 Percentage for all homemakers.

Although the use of fresh noncitrus fruit in a 12 -month period seemed to be universal, there were some slight variations in its use among different segments of the population. As might be expected, the incidence of purchase of all fruit was higher among the better educated homemakers and those in the upper income brackets. Grapes, oranges, and plums or fresh prunes were purchased by a slightly larger proportion of households with children. Cherries, pears, pineapple, plums or fresh prunes, apricots, and nectarines seemed to be more popular with families in the larger metropolitan areas. Apricots and nectarines were purchased by a large number of homemakers in the West, while cherries, pears, pineapple, and plums or fresh prunes found their greatest acceptance in the Northeast (appendix, table 1).

Only 39 homemakers said that in the preceding year they had not purchased at least one of the 11 fresh fruits included in the study. This number was too srall for any detailed analysis.

\section{Reasons for Nonpurchase of Specific Fresh Fruits}

Nonpurchasers of the specific fresh fruits gave a variety of reasons for not having purchased them in the past 12 months. However, some of the reasons given by the homemakers were not a deterrent to their use of the specific fruits or an indication that the fruit itself was disliked. The principal reason given for not purchasing apples, grapes, peaches, pears, and plums or prunes was "have own trees or friends and relatives supply them." Nonpurchasers of apricots and nectarines reported that they were unable to obtain these fruits or were unfamilar with them. 
The small proportion of homemakers who had not purchased bananas and oranges said that they had not done so for reasons related to health--they thought these fruits were difficult to digest or that they were allergic to them.

Over half of the homemakers said that they had not purchased cherries or pineapple; they indicated that these fruits were too expensive or were difficult to prepare (table 2).

\section{Homemakers' Opinions About Amounts of Selected Fresh Fruits They Had Purchased During the Past Five Years}

Purchasers of apples, bananas, grapes, and peaches were asked if they thought they had bought more, less, or about the same amount in the past 12 months, compared with 5 years ago. Those who reported they were purchasing less were more than offset by those who indicated that they were purchasing more, as shown below:

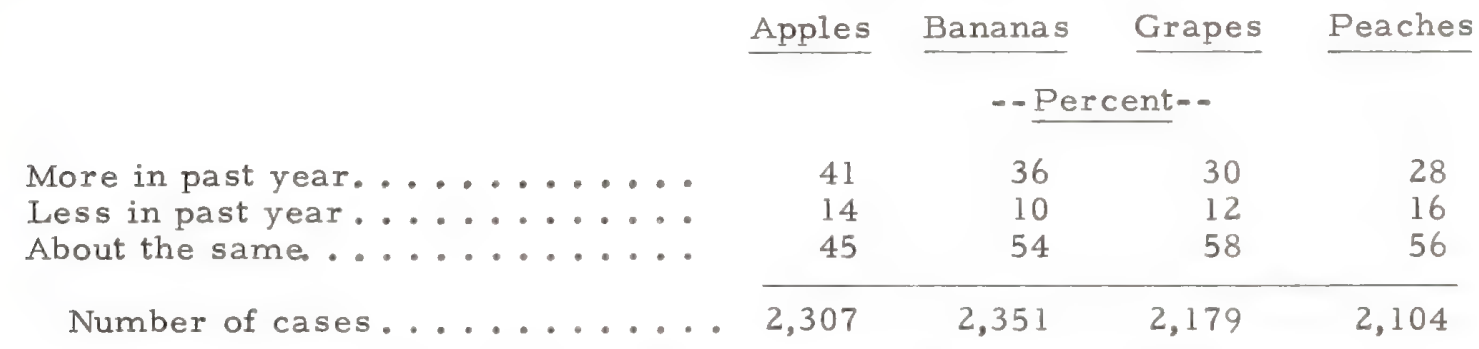

For all four fruits, those respondents who reported having bought more during the past year included relatively higher proportions of:

- younger homemakers

- - families with children

-- upper income, better educated homemakers

-- those living in metropolitan areas

More details can be found in table 3.

\section{Reasons for Buying More or Less Fruit Nowadays}

The major reasons given for buying more fruit now than 5 years ago were "the family is larger" (mentioned by more than 40 percent of the homemakers) and, "children are older-old enough to eat them" (cited by over 30 percent). (table 4)

The main reason given by the homemaker for buying less of each of the fruits now was "the family is smaller" (table 5).

\section{Purchasing of Fresh Fruit by Season}

Homemakers who had purchased apples, bananas, grapes, peaches, pears, plums or fresh prunes were asked the following questions:

"During which season of the year do you buy the greatest amount of fresh (name of fruit)?"

"What amount of fresh (name of fruit) do you usually buy at a time during (that season)?"1

"About how often do you buy (name of fruit) in this quantity during (that season)?"'

"In what other seasons do you buy fresh (name of fruit)?" 
The official dates of the seasons were not mentioned to the respondents, and they therefore made their own interpretations of them. Consequently, there may be some overlap in, for example, fall-winter and summer-fall.

Fall and winter are the seasons in which most homemakers said they bought the greatest amount of fresh apples. Bananas are bought fairly consistently all year. Grapes are purchased in greatest amounts by more homemakers in the fall, followed by summer, then winter.

Peaches and plums or fresh prunes are bought primarily in the summer; about twothirds of the purchasers of these fruits said that this was the only season in which they had purchased them. Homemakers mentioned buying more pears in the fall and summer than at other times. Half of the pear users indicated that these were the only seasons in which they had purchased them (table 6).

On the basis of their responses to these same questions, homemakers were grouped into thirds as nearly as possible and classified as high, medium, or low purchasers of each of the six fresh fruits. This was done to provide a basis for further analysis; however, the grouping itself revealed some interesting facts.

In general, the level of purchases of the six fruits was lowest among households with no children or with children all under age 6 and (except for purchases of peaches and pears) in the lower income bracket, among homemakers over 50, and in small households.

Regional variations were slight; however, the level of purchase of grapes, pears, and plums or prunes tended to be lower in the South, while proportionately fewer peaches were purchased in the West than in other regions.

Homemakers living in the large metropolitan areas tended to purchase larger quantities of grapes and plums or fresh prunes (tables 7-12).

It is interesting to note that homemakers who are heavy purchasers of apples also tend to buy large quantities of the other five fruits (table 13).

\section{Homemakers' Suggestions for Increasing Consumer Purchases of Fresh Fruit}

In an effort to explore several areas of influence on a customer's buying habits, homemakers were asked what they thought a store manager could do to get his customer to buy more of these $1 \mathrm{l}$ fresh fruits. Nearly all the homemakers (94 percent) gave a suggestion. In their opinion, high-quality fruit and attractive displays would be more important influences than other factors in encouraging customers to increase their purchases of fresh fruit. While slightly better than a third of the purchasers of fresh fruit felt that lower prices or sales and specials would get a customer to buy more fruit, better than two-thirds felt higher quality fruit and more attractive displays would accomplish this (table 14).

\section{Fresh Fruits Purchased Last Time}

To get further insight into homemakers' buying patterns and also to establish a basis for more detailed analysis, homemakers were asked what specific fruits they had last purchased. Those fruits that had been mentioned most often as having been purchased in the last 12 months were again cited--6l percent said apples, 57 percent bananas, 28 percent oranges, and 20 percent said grapes. ${ }^{\prime}$

No other fruit was mentioned by more than 8 percent of the homemakers. It should be borne in mind, however, that this study was conducted between mid-November and

1 These percentages add to more than 100 because some homemakers had included more than one kind of fruit in their last purchase. 2,410 homemakers made a total of 4,685 purchases. 
and mid-January; therefore, purchases of summer fruits such as peaches and plums would naturally be low.

Although apples were purchased by the largest proportion of homemakers, bananas (which were second to apples as the fruit last purchased) ranked first in the North Central States (table 15).

\section{Circumstance of Last Purchase}

For each fruit purchased last time, homemakers were asked to choose from three statements the one that came closest to describing how they decided to buy it.

Of the 4,685 fruits purchased:

- 62 percent were planned before the homemaker entered the store

- 24 percent were planned generally but the homemaker decided on the specific fruit in the store

- 12 percent were not planned at all - the homemaker decided to buy fruit in the store

Homemakers planned their purchases of apples, oranges, bananas and grapefruit much more often than their purchases of pears, grapes, or tangerines (table 16).

These responses were then examined in terms of homemakers rather than in terms of number of fruits purchased. Roughly half (53 percent) of the homemakers planned all of their last purchases of fruit, 15 percent bought all their fruit on impulse, 16 percent made planned and impulse purchases, and 14 percent planned to buy fruit, but decided on the specific fruit in the store. Planned fruit purchases were highest among homemakers in the Northeast (table 17).

\section{PACKAGING OF FRUIT}

Homemakers were asked, 'Lii rou buy (name of fruit) loose or already in some kind of bag or container?" Of the tota? atumber of fruits purchased, 72 percent were bought loose and 26 percent were bought packaged. Oranges, apples, and grapefruit were bought packaged to a greater extent than bananas, pears, tangerines, or grapes. No other fruit was mentioned as a last purchase by enough homemakers to draw conclusions (table 18).

When the responses were examined in terms of homemakers, rather than in terms of number of purchases, it was found that 61 percent bought all of their last purchases loose, 16 percent bought all of them packaged, and 21 percent bought some loose and some packaged fruit. Purchasing of loose fruit was higher in the West than in the other regions (table 19).

\section{Preference for Loose and Packaged Fresh Fruit}

Purchasers of fresh fruit were asked, "In general, would you like to buy fresh fruit that is already in some kind of bag or container, or would you rather buy it loose?" The majority of the homemakers (75 percent) said they would prefer to purchase their fruit loose. Packaged fruit was preferred by 16 percent of the homemakers and 9 percent said they had no preference.

Loose fruit was generally preferred more often by Western homemakers, those living in metropolitan areas, better educated homemakers, and those in the middle and upper income brackets (table 20).

Homemakers who said they usually preferred to buy fresh fruit loose were asked if there were any fresh fruits they did not like to buy this way. Only 10 percent said they preferred to buy some kinds packaged (table 21 ). 
Of the homemakers who said they generally would rather buy fresh fruit packaged, 40 percent said they preferred to buy some kinds loose; they mentioned bananas and grapes more frequently as the fruits they preferred purchasing this way (table 22).

\section{Advantages of Buying Fresh Fruit Loose or Packaged}

All homemakers, regardless of their preferences, were asked "What are the advantages of buying fresh fruit loose?" The main responses were:

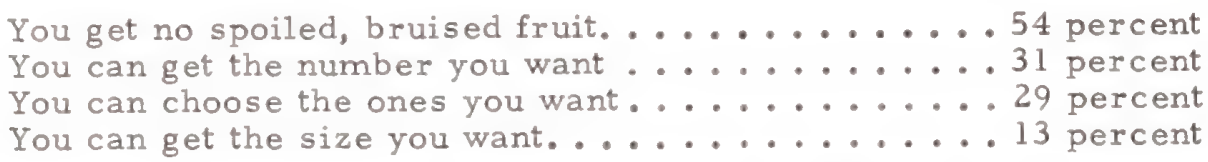

Those homemakers who preferred to buy fresh fruit loose naturally tended to cite the advantages of doing so more often than did homemakers who preferred to buy packaged fruit--16 percent of the latter group said that there were no advantages in buying loose fruit. However, "loose fruit is less expensive" was mentioned more often by those preferring to buy packaged fruit than by those preferring to buy loose fruit (table 23).

All homemakers were also questioned about the advantages of buying packaged fresh fruit (table 24). Thirty-six percent said that there was no advantage, though most of these homemakers, naturally, were people who preferred to buy fruit loose. The main advantages mentioned were:

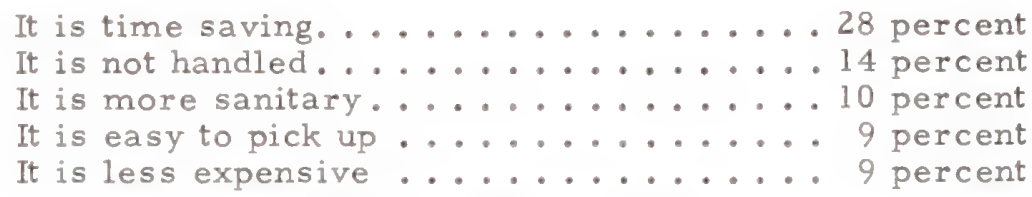

\section{FRESH FRUIT PROFILE}

To understand the homemakers' attitudes toward 15 selected factors in evaluating fruits, two sets of questions were asked--one on the importance attached to the selected factors in buying fruit in general and the other keyed directly to six specific fruits. Two questionnaire forms were used with the order of statements rotated. This was done to minimize position bias in selecting these statements for both questions. The lists contained both positive and negative statements.

The homemakers were asked how they would rate the importance of each when they were considering the purchase of fresh fruits in general--would they rate them very important, fairly important, or not too important (table 28)? "Good for health" (88 percent), "reasonably priced when in season" (79 percent), and "good for snacks or packed lunches" (66 percent) were the positive statements most frequently rated as very important. Negative statements considered most important were "often bruised, blemished" (78 percent), "family does not like them" (75 percent), and "spoils easily" (69 percent).

In interpreting these findings one should consider that the extent to which any factor is important to a homemaker may vary when she is actually considering the purchase of a particular fruit. Thus, although "good for health" was rated "very important" by more respondents than any other factor, it should not be deduced that "good for health" is the homemaker's main consideration when purchasing all fresh fruit.

For each of six fruits--apples, bananas, grapes, peaches, pears, and fresh prunes-homemakers were asked, "Which of these statements do you feel are especiallytrue about (name of fruit)?" While homemakers generally selected the same positive statements for all fruits, the frequency varied according to each fruit's special appeal to the consumer. "Good for health," "good for snacks or packed lunches," and "can be used in many ways" 
were selected most often for most of the fruits. However, about 90 percent felt "good for health, " and "good for snacks or packed lunches" were "especially" true for apples, compared with 66 and 51 percent, respectively, who felt these statements applied to plums or fresh prunes. "Can be used in many ways" was selected by 86 percent for apples, 63 percent for bananas, and 62 percent for peaches, contrasted with 26 percent for grapes, 30 percent for pears--while only 20 percent felt this statement was "especially" true for plums or fresh prunes (fig. 1). Other positive statements selected (but with much less variation in frequency among fruits) were "reasonably priced when in season," "can buy ready to use without further ripening," "good laxative," and "low in calories."

(table 25)

Negative statements, on the other hand, were selected less frequently and generally with proportionately greater variation in frequency. For example, "spoils easily" and "often bruised, blemished" were chosen by between 56 and 42 percent of the homemakers for bananas and peaches, while they were mentioned by only 18 and 5 percent respectively for apples. Other negative statements (not shown in figure 1) were "hard to digest," "hard to find good quality even in season," "hard to find variety liked even in season," "difficult to tell when ripe," and "family does not like them." (table 25)

As explained earlier, each homemaker was classified as a relatively high, medium, or low purchaser of each fruit based on the amount of each fruit purchased during the main purchase seasons. Apples were considered a good laxative by more of the homemakers whose level of purchase was high than of those whose level of purchases was low. Similarly, high purchasers of bananas more often selected "good for snacks or packed lunches," and high purchasers of grapes more often selected "reasonably priced when in season."

Homemakers whose purchases of peaches and pears were high selected "can be used many ways," "reasonably priced when in season," "good laxative," and "good for snacks or packed lunches" more often than did homemakers whose purchases were low. High purchasers of pears also selected "good for health" more often. Low purchasers of peaches, on the other hand, more often selected "difficult to tell when ripe."

For plums, "can be used many ways," "reasonably priced when in season," and "good for snacks or packed lunches" were most often selected by those with high purchase levels. Surprisingly, this same group also selected "often bruised or blemished" and "spoils easily" most often. "Messy to eat" was most often selected by homemakers whose level of purchases of grapes was low.

Analysis of both positive and negative statements selected by nonusers of each of these fruits revealed some interesting differences. As might be expected, positive statements were selected by a somewhat smaller proportion of nonusers than users; however, a higher proportion of nonusers of apples selected "a good laxative" and "low in calories" than did users. The large proportion of nonusers who selected negative statements for the six fruits seemed to reinforce the reasons they gave for not having used them during the past year (table 2). In some instances a smaller proportion of nonusers than users selected negative statements; obviously these characteristics of the fruit had no appreciable effect on homemakers' nonpurchase of them (tables 26 and 27).

\section{Homemakers' Dislike of Fresh Fruit}

In order to further evaluate homemakers' attitudes toward apples, apricots, cherries, grapes, nectarines, peaches, pears, pineapple, and plums or fresh prunes, homemakers were questioned on their dislikes, if any, of these fruits.

Relatively high proportions of homemakers considered pineapple hard to prepare and were not familiar with nectarines. No other single criticism of any of the fruits was made by more than 11 percent of those who had purchased some fresh fruit during the last year (table 29). 
With the exception of pineapple, better than half of the homemakers said there was nothing they disliked about any of the specific fruits. Of the 63 percent who expressed some dislike of pineapple, over half objected not to the fruit itself but to the difficulty in preparing it. The proportion of homemakers who said there was nothing they disliked about these fruits varied. A relatively high number of homemakers in the West said there was nothing they disliked about apricots, cherries, and nectarines; while generally more of the respondents in the Northeast and South mentioned that they had no dislike of grapes, peaches, pears, pineapple, or plums and fresh prunes. Older homemakers seemed to object the least to apricots, cherries, peaches, and pineapple (tables 30 and 31).

The negative attitudes of homemakers who had bought each of these nine fruits during the past year, and of those who had not, were examined separately. As would be expected, nonpurchasers generally expressed more dislikes and expressed them more frequently than did purchasers. Moreover, the main dislikes of nonpurchasers were different from those of purchasers except for pineapple--both purchasers and nonpurchasers indicated by large proportions that this fruit was difficult to prepare (table 31 ).

\section{FRESH APPLES}

\section{RAW APPLES}

\section{Where Fresh Apples are Bought}

The use of fresh apples in the home is almost universal. Better than 9 out of 10 homemakers (94 percent) indicated that they had purchased them in the last year.

When homemakers were asked where they purchased apples most frequently, the majority of them mentioned the supermarket. Homemakers were also asked where occasional purchases were made. They made the following replies:

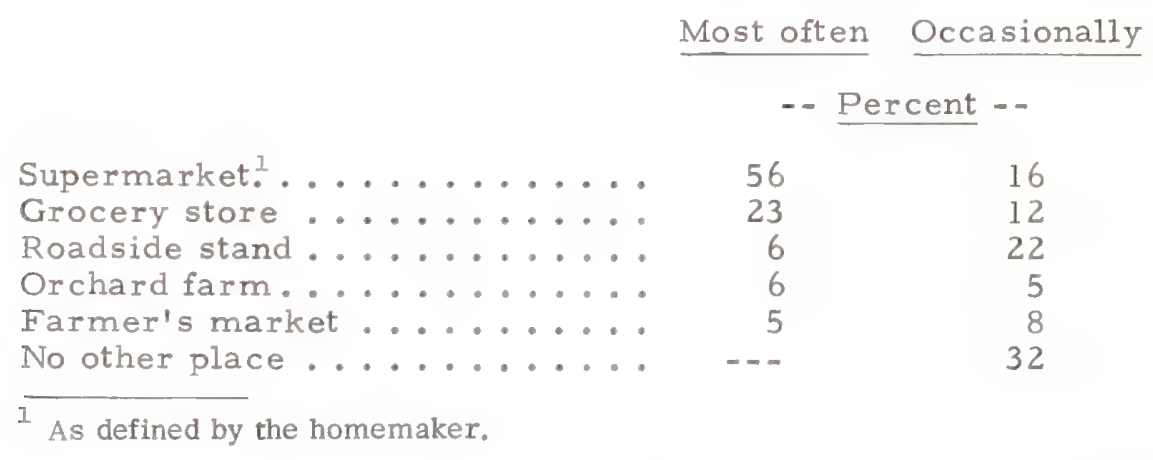

Of the various outlets at which apples were bought, supermarkets were mentioned by a relatively high proportion of Northeastern homemakers, homemakers living in metropolitan areas, and homemakers in the upper income bracket.

Homemakers in rural areas were equally likely to purchase apples from supermarkets and grocery stores. Roadside stands were frequented by a smaller proportion of homemakers living in the South, and in rural areas, homemakers with low incomes, older homemakers, and those with little education. Although fewer homemakers purchased apples at farmers' markets, orchards, and roadside stands, those who did tended to be high purchasers of apples (table 32 ). 


\section{STATEMENTS SELECTED BY HOMEMAKERS}

\section{ABOUT VARIOUS FRUITS \\ POSITIVE STATEMENTS}

GOOD FOR
HEALTH
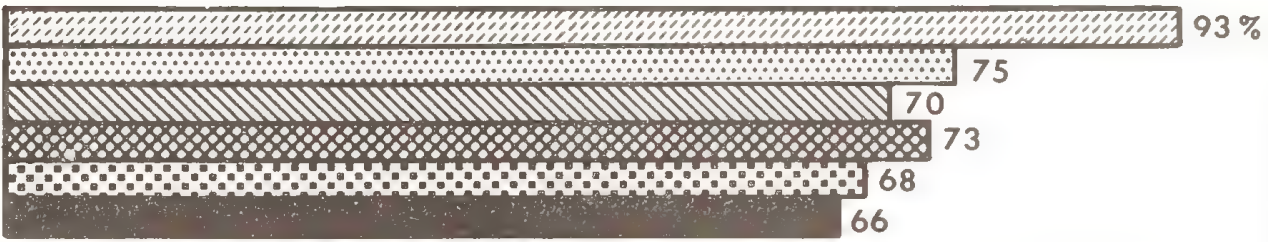

GOOD FOR

SNACKS AND

PACKED

LUNCH

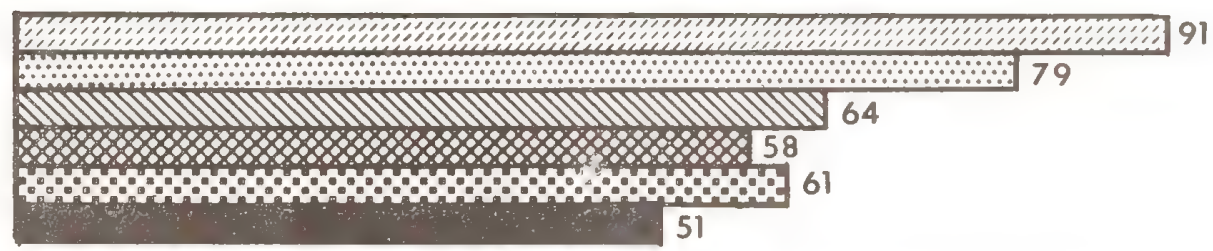

CAN BE USED

MANY WAYS

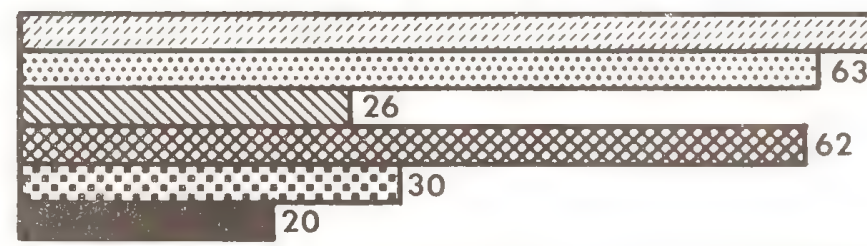

OFTEN BRUISED OR

BLEMISHED

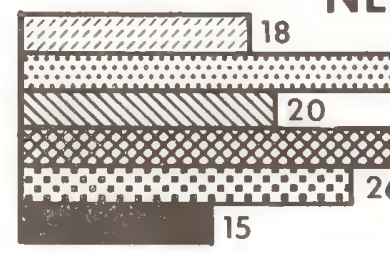

Apples

…… Bananas

Grapes

Peaches

SPOILS EASILY

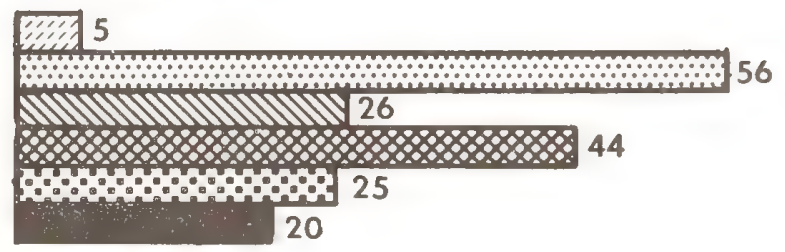

Pears

Plums

20

MESSY TO EAT
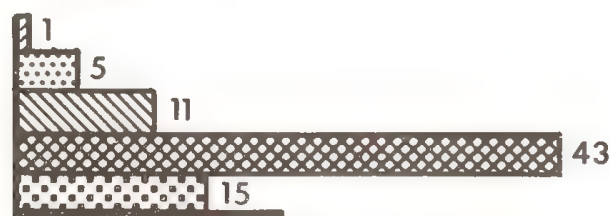
At the time of the survey the majority of the homemakers said they had used apples at least once a week during all four seasons of the past year: ${ }^{2}$

\section{Percent}

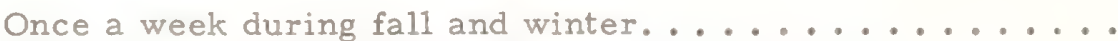

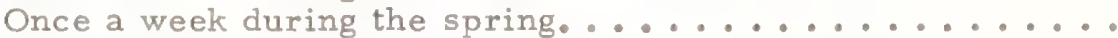

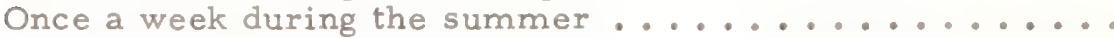

Use of apples at least once a week in the fall, winter, and spring was mentioned by higher proportions of Northeastern homemakers and of those in the upper income group, while a higher proportion of homemakers living in large metropolitan areas reported using apples at least once a week in the spring and summer (table 33).

\section{Homemakers' Reasons for Using Fresh Apples Less Often than Once a Week}

Homemakers who reported using fresh apples less than once a week during any season were asked why they did not use them more often. The main reasons given varied according to the season under discussion.

Reasons for using less often than once a week
Fall and winter Spring Summer

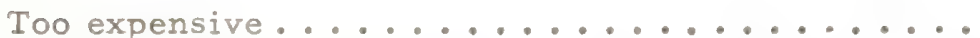

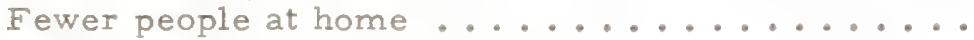

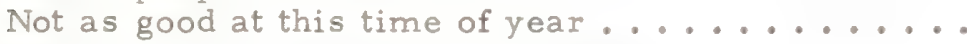

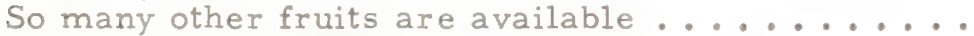

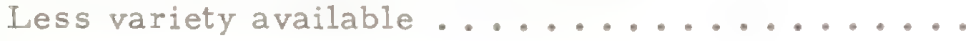

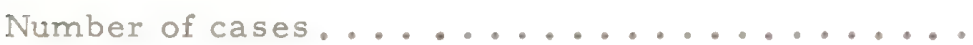

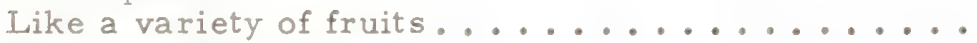

\begin{tabular}{rrr} 
& $--\frac{\text { Percent }}{20}$ & \\
16 & 10 & 16 \\
14 & 6 & 5 \\
13 & 25 & 5 \\
5 & 18 & 20 \\
2 & 13 & 35 \\
3 & 799 & 14 \\
\hline 327 & & 881
\end{tabular}

See table 34 for further details.

A higher proportion of homemakers in the upper income brackets cited "not as good this time of year" as a reason for using apples less often than once a week in the spring. "So many other fruits are available" was mentioned as a reason for infrequent use during summer and spring by a higher proportion of better educated homemakers and those in the upper income brackets. A higher proportion of homemakers with older children said that apples were too expensive to use as often as once a week in the spring and summer. "Less variety available" was mentioned less frequently by homemakers in the west and more often by respondents in the upper income brackets as their reason for using apples less than once a week in the summer. In the spring, homemakers in the west are likely to use fresh apples less frequently than those in the Northeast because they "like a variety of fruits" (table 35).

\section{Ways in Which Homemakers Use Raw Apples in The Home}

Homemakers who had purchased apples were asked, "During the past year, in which of these ways have you used raw apples in your home: Eaten out-of-hand? Salads? Fruit cups?" In answer to these questions:

97 percent said they had eaten apples out-of-hand

63 percent said they had used them in salads

31 percent said they had used them in fruit cups

2 Official dates of the seasons were not mentioned to the homemakers; they therefore made their own interpretations of them. 
Fewer homemakers in the Northeast than in other regions reported using raw apples for salads; fewer North Central homemakers mentioned using apples for fruit cups.

However, proportions eating raw apples out-of-hand did not vary significantly by region (table 36).

\section{Occasions When Fresh Apples Are Eaten Raw}

Homemakers who use raw apples were asked, "When are apples eaten raw most often by your family?" and "When else are they eaten this way?" For both questions, a list of possible answers was read to homemakers--"meals at home, "packed lunches," "daytime snacks" and "evening snacks." Raw apples were used most often for daytime snacks; use for evening snacks was also mentioned frequently.

Answers to the questions are shown below:

$\begin{array}{cccc}\text { Occasions when fresh apples } & \text { Most often } & \text { Other times } & \text { Total } \\ \text { are eaten raw } & \text { eaten raw } & \text { eaten raw } & \end{array}$

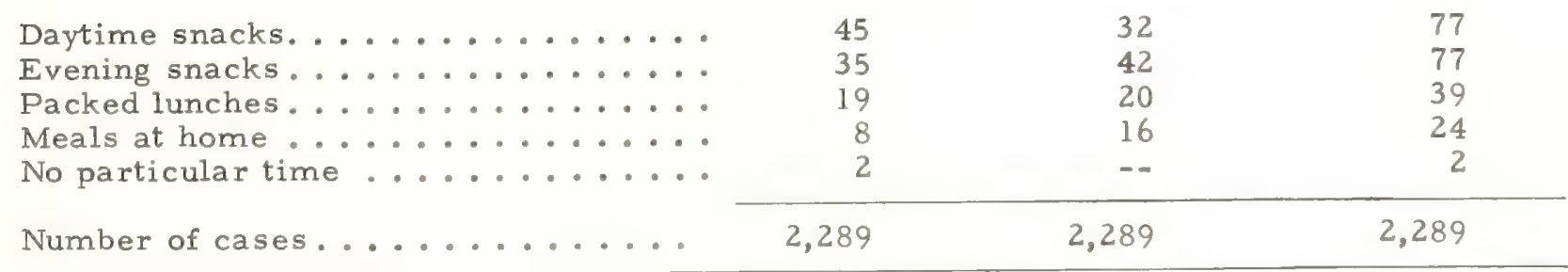

Analysis by homemakers' background characteristics revealed several variations from the general pattern of use. The use of raw apples in packed lunches and with meals at home showed the greatest variation among the different population segments.

In comparison with the total results, which show that raw apples were used for packed lunches to a greater extent than for meals at home, they were used to about the same extent for these purposes by Southern homemakers, those in the low income category, and in households without children.

Raw apples are used for packed lunches least often by homemakers in the South, those living in rural areas, those homemakers with lower incomes, those over 50 years of age, those small households, and those in homes where there are no children.

Raw apples are used for meals at home by smaller proportions of homemakers in the Northeast, those living in large metropolitan areas, those in the younger group, and those with children (table 37 ).

\section{Qualities Homemakers Look for When Choosing Fresh Apples for Eating Raw}

In order to establish some criteria for the apple industry in the marketing of their product, the homemakers were asked to select from a list of 23 qualities those they 
considered when choosing apples for eating raw and for cooking or baking. The qualities selected most often for apples to be eaten raw were:

\section{Qualities}

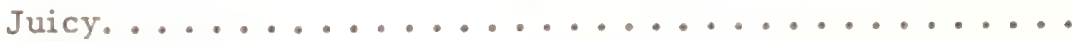

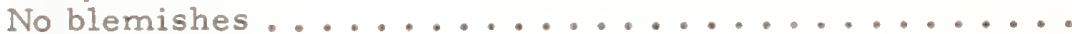

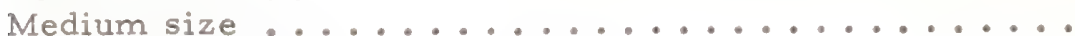

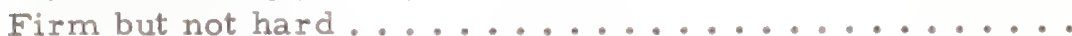

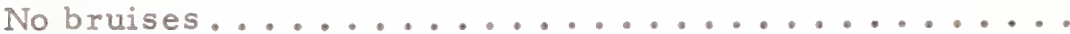

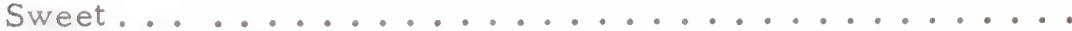

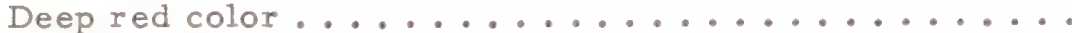

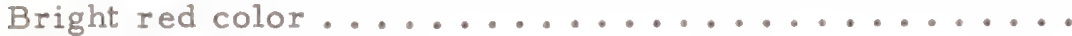

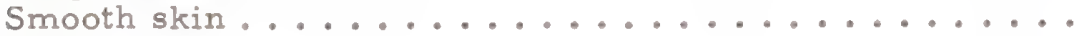

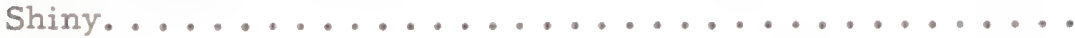

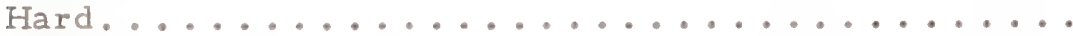

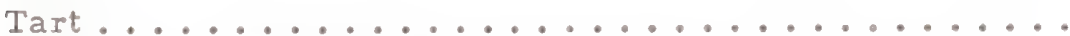

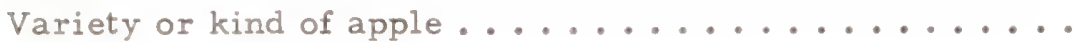

\section{Percent}

87

71

65

62

62

50

43

41

33

26

24

21

27

Clearly, when looking for fresh apples for eating raw, most homemakers want apples that are red, juicy, unblemished, not bruised, of medium size, firm but not hard, and sweet (table 38 ).

\section{Varieties of Apples Homemakers Prefer for Eating Raw}

Users of raw apples were asked, "Which variety or kind of apples do you prefer for eating raw?" Delicious apples were easily the most frequently mentioned, followed by McIntosh, Jonathan, and Winesap or Stayman Winesap in that order. However, as might be expected, there was considerable variation by region. Certain varieties tended to be more popular in the area where they are grown in the largest quantity. McIntosh apples were more popular in the Northeast; Jonathan apples were more popular in the North Central States. Although overall the most frequently mentioned, the Delicious apple was preferred most by homemakers in the South and West. However, there was little regional variation in the proportions who selected the Winesap or Stayman Winesap.

\begin{tabular}{|c|c|c|c|c|c|}
\hline $\begin{array}{c}\text { Main varieties of apples preferred } \\
\text { for eating raw }\end{array}$ & $\begin{array}{l}\text { U.S. } \\
\text { total }\end{array}$ & Northeast & $\begin{array}{l}\text { North } \\
\text { Central } \\
\text { States }\end{array}$ & South & West \\
\hline & \multicolumn{5}{|c|}{ - Percent -- } \\
\hline 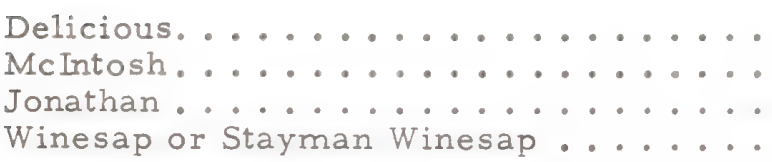 & $\begin{array}{l}58 \\
23 \\
17 \\
16\end{array}$ & $\begin{array}{r}44 \\
60 \\
1 \\
11\end{array}$ & $\begin{array}{l}57 \\
16 \\
40 \\
13\end{array}$ & $\begin{array}{r}62 \\
5 \\
5 \\
23\end{array}$ & $\begin{array}{r}72 \\
9 \\
26 \\
14\end{array}$ \\
\hline 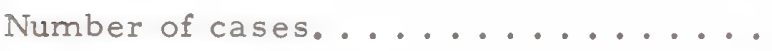 & 2,289 & 590 & 669 & 714 & 316 \\
\hline
\end{tabular}

See table 39 for further information.

As mentioned before, homemakers were asked to select from a list of 23 qualities those they preferred when choosing eating apples. The qualities selected were examined in terms of the varieties they preferred. However, only four varieties were mentioned by enough homemakers to permit analysis.

Regardless of the variety preferred, homemakers wanted a juicy apple without blemishes or bruises, of medium size, and firm, but not hard. However, when Delicious or McIntosh was the preferred variety, "sweet" was most often selected as a quality 
looked for in an eating apple; while Jonathan or Winesap or Staymen Winesap apples were preferred by those who looked for a "tart" apple.

Deep red color was most often mentioned by the homemaker preferring Delicious or Winesap or Stayman Winesap apples; bright red was looked for by those preferring Jonathan apples.

\begin{tabular}{|c|c|c|c|c|}
\hline \multirow[b]{2}{*}{ Qualities looked for } & \multicolumn{4}{|c|}{ Varieties preferred for eating raw } \\
\hline & Delicious & Jonathan & $\begin{array}{l}\text { Winesap or } \\
\text { Stayman } \\
\text { Winesap }\end{array}$ & McIntosh \\
\hline & \multicolumn{4}{|c|}{-- Percent -- } \\
\hline Juicy. . . . . . . . . . . . . . . & 90 & 90 & 86 & 85 \\
\hline 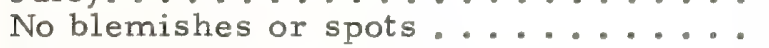 & 73 & 79 & 69 & 71 \\
\hline 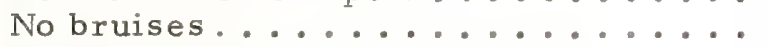 & 65 & 69 & 60 & 60 \\
\hline 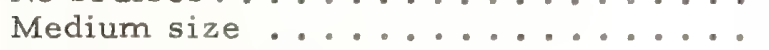 & 64 & 71 & 66 & 67 \\
\hline 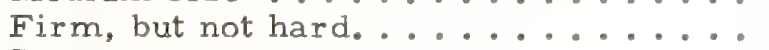 & 64 & 62 & 59 & 67 \\
\hline 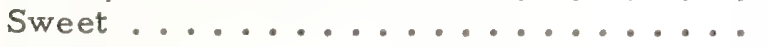 & 57 & 44 & 40 & 46 \\
\hline 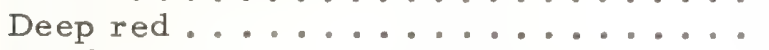 & 46 & 37 & 44 & 39 \\
\hline 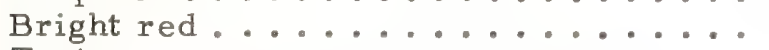 & 41 & 49 & 41 & 42 \\
\hline 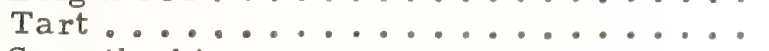 & 18 & 36 & 39 & 18 \\
\hline 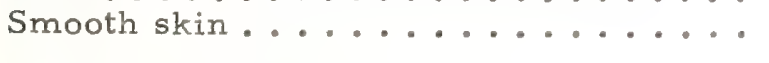 & 34 & 36 & 34 & 31 \\
\hline 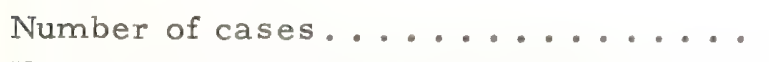 & 1,317 & 393 & 357 & 531 \\
\hline
\end{tabular}

See table 40 for further details.

\section{APPLES FOR COOKING}

\section{Use of Fresh Apples for Cooking or Baking}

Homemakers who had bought fresh apples in the preceding year were asked, "During the past year, have you used fresh apples for cooking or baking?" Eighty-four percent said that they had used them for this purpose. The proportions were highest among:

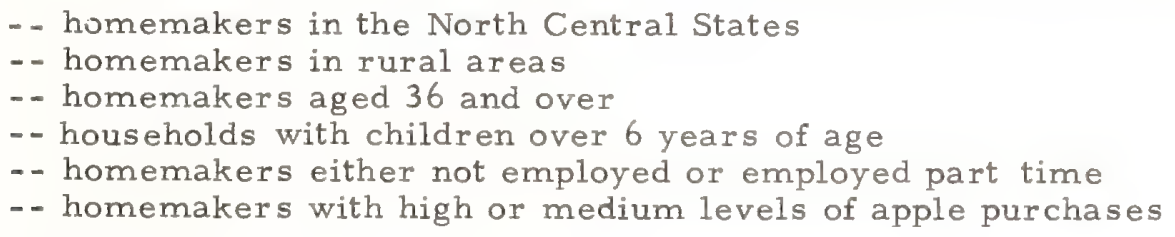

See table 41 .

Homemakers who reported not having used fresh apples for cooking or baking in the past year gave a variety of reasons for this (table 44). The following reasons were mentioned by 10 percent or more of these homemakers:

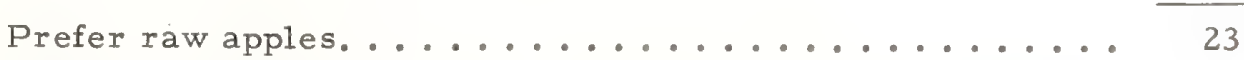

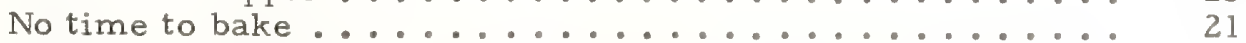

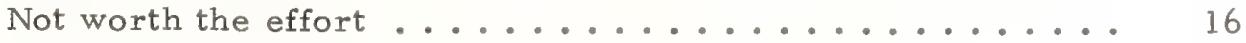

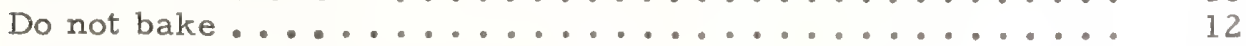

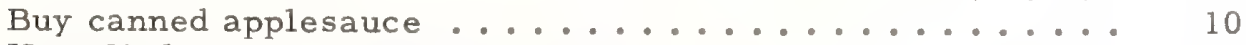

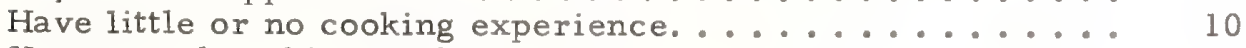

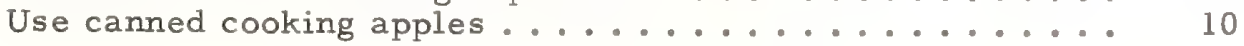


Users of fresh apples for cooking or baking were asked, "During the past year, in which of these ways have you used fresh apples for cooking or baking; homemade applesauce, baked apples, apple cake, apple pie, other desserts, some other way?": 84 percent said apple pie, 66 percent said baked apples, 64 percent said homemade applesauce, and 30 percent said apple cake.

While the use of fresh apples for baking apple pie was mentioned more often than the other uses by homemakers in all segments of the population, homemakers in the Northeast and the West, in large metropolitan communities, and in households without children were less likely to bake apple pies. In general, however, larger proportions of homemakers in these segments of the population made applesauce.

Baked apples seemed to be favored more by older homemakers and those without children. Apple cake tended to be a regional specialty, with higher proportions of homemakers in the Northeast and North Central areas using apples this way. Over one-third of the respondents mentioned other desserts but no one specific dessert was cited often enough to warrant a detailed discussion (table 45 ).

\section{Proportions of All Fresh Apples Bought That Are Used for Cooking or Baking}

Homemakers who had used fresh apples for cooking or baking were asked, "What percentage of all the fresh apples bought during the past year did you use for cooking or baking?"':

11 percent said they had used 75 percent or more of all their fresh apples for cooking or baking

28 percent said they had used between 50 percent and 74 percent for cooking and baking

29 percent said they had used between 25 and 49 percent

31 percent said they had used less than 25 percent

The level of purchase of apples apparently was unrelated to the proportion of fresh apples used for cooking or baking. About 40 percent of homemakers in both the highpurchase and low-purchase groups used half or more of the fresh apples they purchased for cooking or baking.

In general, there was little variation in the proportion of apples used for cooking or baking by homemakers in various segments of the population; however, comparatively high proportions of homemakers over 50 , those in households without children and those living in small households said that they used 75 percent or more of the fresh apples purchased during the past year for cooking and baking (table 46).

\section{Qualities Looked for in Apples for Cooking or Baking}

When homemakers choose apples for cooking or baking, color is not as important as it is when they choose apples for eating raw, nor is there as much agreement among them on preference for a particular color. In a "cooking" apple, the homemaker is more concerned with getting a juicy one that is firm but not hard, tart, of medium size, without blemishes or bruises.

The following qualities were selected most often for cooking or baking apples:

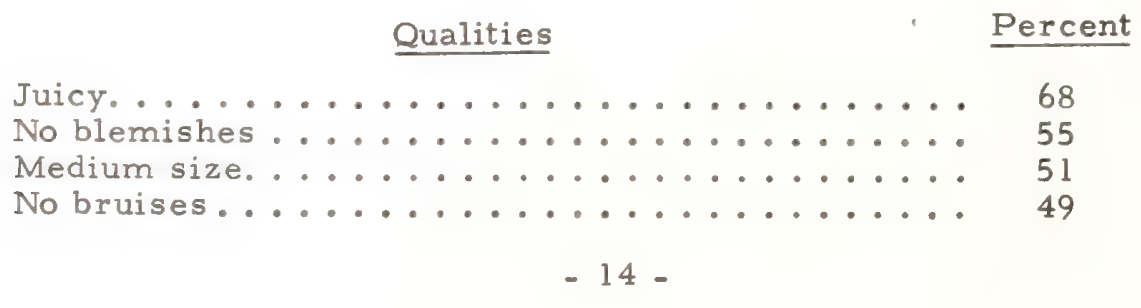




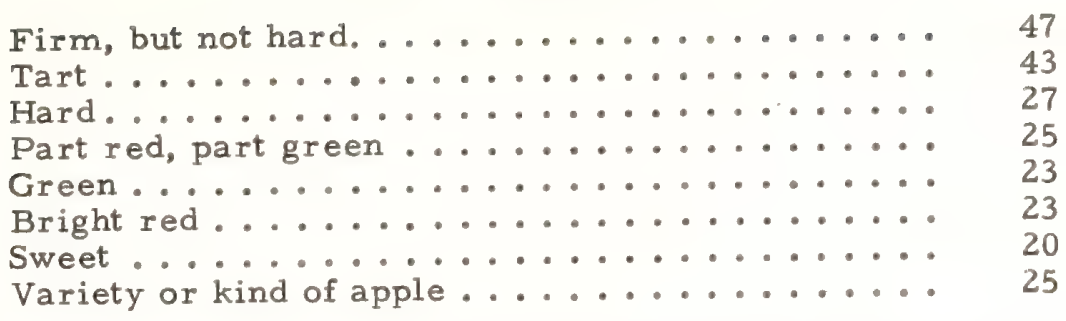

The variety or kind of apple to use (the only other factor on the list mentioned by as many as 1 in 4), was of as much concern to homemakers when choosing fresh apples for cooking or baking as it was when choosing apples for eating raw.

Preference for color of apples for cooking or baking varied somewhat among regions. In the North Central States, part red, part green, and bright red apples were preferred to a greater extent than green or deep red apples. Green apples were preferred by a majority of the homemakers in the West and by very few in the South (table 42).

\section{Varieties or Kinds of Apples Homemakers Prefer for Cooking or Baking}

The majority of homemakers who used apples for cooking or baking indicated that sometimes they bought a certain variety especially for this purpose. A little over onefourth $(27$ percent) indicated that they did not buy a special variety. The main reasons for not doing so were "prefer an all-purpose apple," "use whatever is on hand," or "use eating apples whose qualities they prefer" (table 47).

All homemakers who used fresh apples for cooking or baking were asked: "Which variety or kind of apples do you prefer for cooking or baking?" As was true in homemakers' preferences of varieties for eating raw, preferences in varieties to be used for cooking or baking varied considerably from region to region. Winesap or Stayman Winesap most frequently headed the list in the South. McIntosh was the most popular variety in the Northeast, Jonathan in the North Central States, and Pippin was more popular in the West.

\begin{tabular}{|c|c|c|c|c|c|}
\hline $\begin{array}{c}\text { Main varieties of apples preferred } \\
\text { for cooking or baking }\end{array}$ & $\begin{array}{l}\text { U.S. } \\
\text { total }\end{array}$ & Northeast & $\begin{array}{c}\text { North } \\
\text { Central } \\
\text { States }\end{array}$ & South & West \\
\hline & \multicolumn{5}{|c|}{-- Percent -- } \\
\hline Winesap or Stayman Winesap......... & 21 & 10 & 15 & 41 & 12 \\
\hline 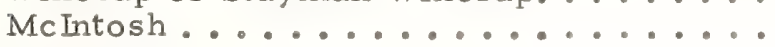 & 17 & 39 & 16 & 3 & 8 \\
\hline 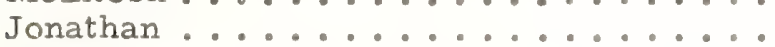 & 17 & 2 & 35 & 11 & 19 \\
\hline Pippin . . . . . & 4 & -- & * & * & 30 \\
\hline 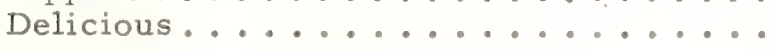 & 9 & 7 & 7 & 13 & 13 \\
\hline 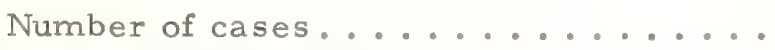 & 1,930 & 508 & 598 & 574 & 250 \\
\hline
\end{tabular}

*Less than 1 percent.

See table 43 for further details.

Homemakers' preferences for different varieties of apples were examined in terms of all the qualities they said they look for when choosing fresh apples for cooking or baking. Regardless of the variety they preferred, homemakers looked mainly for apples 
that are juicy, unblemished, of medium size, firm but not hard, and tart. There were exceptions, however. For example, homemakers who preferred Delicious or McIntosh apples mentioned tart less frequently as a quality looked for.

\begin{tabular}{|c|c|c|c|c|}
\hline Qualities looked for & $\begin{array}{c}\text { Winesap } \\
\text { or Stayman } \\
\text { Winesap }\end{array}$ & McIntosh & Jonathan & Delicious \\
\hline & \multicolumn{4}{|c|}{-- Percent -- } \\
\hline Juicy. . . . . . . . . . . . . . . & 69 & 73 & 72 & 73 \\
\hline No blemishes or spots .......... & 55 & 57 & 62 & 60 \\
\hline 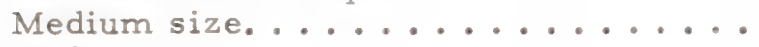 & 59 & 45 & 60 & 56 \\
\hline 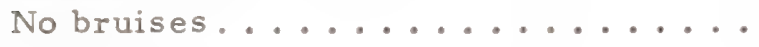 & 50 & 49 & 64 & 52 \\
\hline 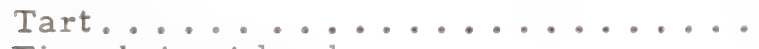 & 52 & 33 & 49 & 29 \\
\hline 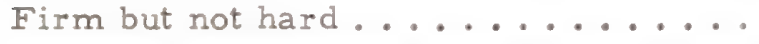 & 47 & 54 & 62 & 56 \\
\hline
\end{tabular}

See table 40 for further details.

\section{PROBLEMS WITH APPLES}

\section{Difficulty in Finding Good Fresh Apples}

Homemakers were asked what difficulties they had encountered in purchasing fresh apples for any use during the past year. Only about one in seven (14 percent) mentioned any problems. Most said that they had encountered these problems mainly during the spring and summer. They were also asked if the difficulty occurred in purchasing any special variety or kind of apple. Less than half of those who had difficulty said that it did; no one variety was mentioned by as many as one-fourth (tables 48-49).

Incidence of Disappointment in Apples Bought during the Past Year

Homemakers who had purchased fresh apples during the past year were asked, "Have you been disappointed in apples that you have bought during the past year?" About one in four ( 28 percent) said that they had been.

Disappointment was expressed by a higher proportion of homemakers in the West than in other regions (table 50 ).

Those who had been disappointed were asked, "In what ways?"

25 percent referred to interior blemishes and deterioration

22 percent said the apples were dry

21 percent said they were soft, mushy, soggy

16 percent said they had no taste, were flat

15 percent said they were bruised, blemished

13 percent said they were mealy, powdery

11 percent referred to complete spoilage

11 percent said they were sour, not sweet

10 percent said they were too hard

See tabie 51 for further details.

When asked where they had bought the apples they did not like, 61 percent of the homemakers cited supermarkets and 21 percent mentioned grocery stores. No other place was mentioned by more than 6 percent of the homemakers (table 52 ). 
The following tabulation shows the various outlets where homemakers purchased apples most often and the percentage who were disappointed in the apples purchased from these outlets.

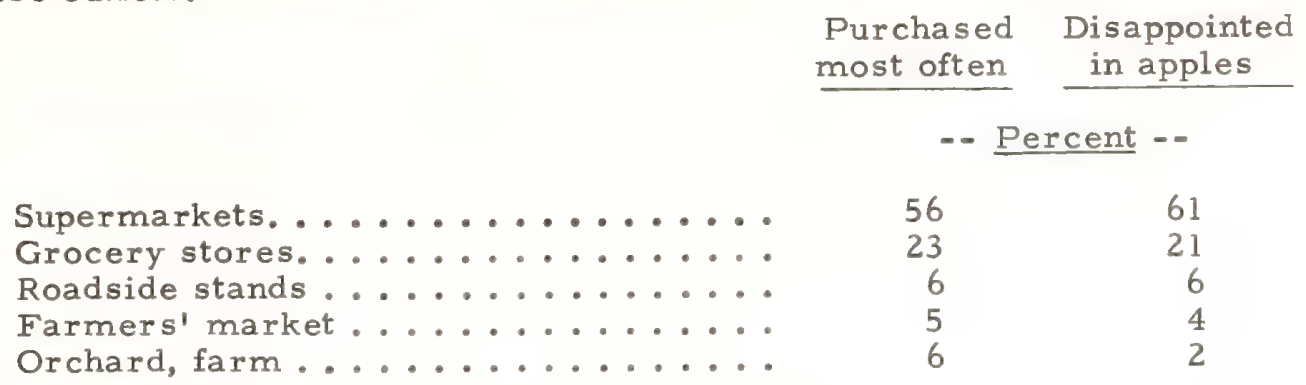

Obviously, the incidence of purchase from an outlet closely paralleled the proportion of homemakers who expressed disappointment in apples purchased from these outlets. Purchases from orchards or farms seemed to be less disappointing, however too few homemakers mentioned such purchases to be conclusive.

\section{Incidence of Purchasing Substitutes for Fresh Apples}

All homemakers who had purchased fresh apples during the past year were asked, "Have you bought something else at any time in the past year when you would have preferred to buy apples?" Only about one in seven homemakers (14 percent) said they had. When asked what they had bought the last time this happened, almost half said they had purchased bananas, and a smaller proportion mentioned oranges. No other fruit was mentioned by as many as a tenth of those who bought substitutes (table 53).

When asked what circumstance led to their buying a substitute, about two-fifths mentioned poor quality--the apples available were either old, dried up, bruised, or just didn't look good. About one-fifth stated that price was a factor (table 54).

\section{APPLESAUCE}

\section{INCIDENCE OF PURCHASING PROCESSED APPLESAUCE DURING THE PAST YEAR}

All homemakers interviewed, including the 39 homemakers who said they had not bought any fresh fruit during the past year, were asked about their purchases of applesauce during the past 12 months. The 71 percent who had purchased it included a relatively high proportion of homemakers living in the Northeast and in metropolitan areas, better educated homemakers, and homemakers in the upper income brackets.

Earlier in the interview, homemakers were asked whether or not they had used fresh apples for making applesauce. The results of both questions revealed that better than 8 in 10 had used some type of applesauce during the past year--36 percent had used both processed and homemade applesauce, almost an equal proportion had used processed only, and 14 percent said they had used only homemade applesauce (table 55).

Purchasers of processed applesauce were asked, "How do you generally use the applesauce you buy?"

62 percent said as a side dish with meat

42 percent said as a dessert

12 percent said in recipes for cake, cookies

8 percent said as a garnish on meat

5 percent said as a breakfast fruit

5 percent said with pancakes

See table 56 for more detailed information. 
Purchasers of processed applesauce were also asked, "Which do you prefer, homemade applesauce or the kind you buy in a store?"

45 percent said they preferred homemade applesauce

36 percent said they preferred processed applesauce

19 percent said they had no preference

Preference for homemade applesauce was strongest among homemakers in the Northeast and those in the North Central States (table 57).

As might be expected, the majority of homemakers who had used both processed and homemade applesauce preferred the homemade variety, while the largest proportion of those who had not used any homemade applesauce during the past year preferred the processed.

Homemakers who had--

\begin{tabular}{l} 
Used both home- \\
made and proc- \\
essed applesauce \\
\hline
\end{tabular}

Percent

Preferred homemade applesauce.........

Preferred processed applesauce.........

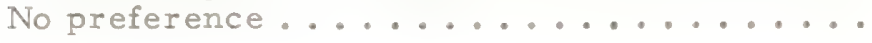

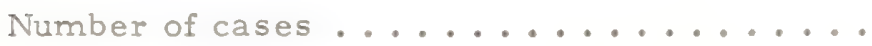

Used processed applesauce only

$\underline{\text { Percent }}$

26

54

20

\begin{tabular}{lr}
63 & 26 \\
19 & 54 \\
18 & 20 \\
\hline 896 & 851
\end{tabular}

Homemakers' main reasons for preferring homemade applesauce were that they could flavor it to their own taste, that it had a better taste than processed applesauce, and that it had a fresh taste. Those who preferred processed applesauce gave "more convenient" as their main reason (table 58).

\section{HOMEMAKERS' OPINIONS ABOUT THE WAY GOOD APPLESAUCE SHOULD LOOK AND TASTE}

How should applesauce look and taste? Should it be thick and chunky or thin and smooth? To get this information, all homemakers were asked to describe how "good" applesauce should look and taste.

Homemakers were about equally divided in their taste preferences--27 percent preferred a sweet applesauce and 23 percent wanted one that was not too sweet and not too tart. They also preferred a medium-thick, smooth applesauce that was yellowish or light in color (table 59).

To get as complete a description as possible of color and consistency preferences, homemakers who did not mention them were asked their preferences for these two factors.

About a fourth of the homemakers voluntarily stated a preference for medium-thick applesauce; about one in eight expressed a preference for thick applesauce. When asked directly, equal proportions mentioned these two factors.

On color, the largest proportion of homemakers voluntarily expressed a preference for yellow applesauce; the next highest proportion preferred a light-colored applesauce. When homemakers who did not mention color were asked their preference, the relative positions of the two did not change, but the proportion preferring yellow applesauce was clearly the largest (table 60). 
The opinions of homemakers preferring homemade applesauce and those preferring canned applesauce were examined separately.

Basically, the two groups did not differ in what they considered "good" applesauce; however, there were some variations in taste and color preferences. Those who preferred homemade applesauce were more likely to prefer cinnamon or other spices as a seasoning. While homemakers preferred yellow or light-colored applesauce, a large proportion of those who preferred the homemade variety expressed a preference for tan or pink applesauce (table 61).

\section{PROCESSED FRUITS}

In order to get a complete picture of the use of noncitrus fruit, one must get information on both fresh and processed fruits.

Homemakers were asked which of nine canned fruits they had purchased during the last year. It was found that:

86 percent said they had bought canned pineapple

86 percent said they had bought canned fruit cocktail or salad

83 percent said they had bought canned peaches

65 percent said pears

43 percent said apricots

36 percent said sweet cherries

34 percent said apples

32 percent said plums or prunes

28 percent said sour cherries

Only 3 percent of the homemakers had not bought any of these canned products.

In general, these products had been purchased by larger proportions of homemakers in the higher income brackets and those with better educations.

In the Northeast, fewer homemakers had bought sour cherries and apples; in the South, smaller proportions had bought fruit cocktail or salad, pears, apricots, and plums or prunes. Purchases of sweet cherries were reported by fewer of the homemakers in the West (table 62).

Homemakers' purchases of canned fruits were compared with their purchases of fresh fruits. Purchases of all canned fruits except pineapple were highest among homemakers who had bought the same fresh fruits during the past year (table 63).

\section{JUICES}

Juices, a natural byproduct of fresh fruits, are also of interest in a study such as this. Therefore, homemakers were asked which of four noncitrus juices they had purchased in the past 12 months.

63 percent said they had bought grape juice

62 percent said they had bought pineapple juice

40 percent said they had bought prune juice

38 percent said they had bought apple juice

13 percent said they had bought none of these juices

As with canned fruit, homemakers who purchased the four juices tended to have higher incomes and to be better educated. A relatively larger proportion of homemakers living in the Northeast, in the West, and in large metropolitan areas purchased apple juice. Homemakers living in the Northeast and in metropolitan areas were more likely to purchase prune juice (table 64). 


\section{PRUNES}

Prunes are well known in American households. More than 7 out of 10 homemakers said they had used either canned prunes, dried prunes or prune juice during the past year; almost 5 in 10 had used at least two forms of prunes; and about 6 in 10 said they had used dried prunes. Over half of the latter group mentioned that they had served dried prunes at least once a month.

6 percent said they served dried prunes more than once a week

8 percent served them once a week

18 percent served them two or three times a month

23 percent served them once a month

44 percent served them less than once a month

Smaller proportions of the younger homemakers said they had used prunes during the past year. Also, this group had used prunes less frequently than the older groups. Among homemakers under 36 years of age, only 47 percent had used prunes; among homemakers 36 and older, 64 percent had used them. Use of prunes at least once a month was reported by 35 percent of those under 36 years of age and from 54 to 64 percent of those 36 and over (tables 65, 66, 67).

\section{Attitudes Toward Prunes}

The homemaker's major reason for using prunes is that it has a laxative quality-over 4 out of 10 mentioned this. Reasons related to health were mentioned by 2 users in 10. No other reason was given by as many as 2 out of 10 homemakers (table 68).

Most users could find no fault with prunes--only about 1 in 10 indicated that there was something they did not like about using dried prunes. In answer to the question, "What, if anything, don't you like so well about them?" the only criticisms made by as many as 3 percent were about price, taste, and the presence of pits or seeds (table 69).

Homemakers' main reasons for buying dried prunes were examined in terms of the frequency with which they use them. Homemakers who thought prunes served as a laxative, were good for health, and could be used as a breakfast fruit tended to use them more frequently than other homemakers. As might be expected, those who liked them for variety tended to use them least often (table 70).

Homemakers who said they had not purchased dried prunes during the past year were asked, "How come you don't buy dried prunes?" Many of their reasons were general: "don't care for them," "just don't bother to buy them," "prefer other forms of the fruit." About 2 in 10 commented that they disliked the taste. A small proportion felt that dried prunes were too expensive or said they preferred other fruit (table 71 ).

\section{RAISINS}

The proportion of homemakers in the United States who reported they used raisins in their homes during the past year had not changed since a previous study conducted in 1957.3 Then, as now, 83 percent of the American homemakers used raisins. Homemakers in the West tended to use raisins more frequently than those in other regions, although the reported incidence of use did not vary significantly. A larger proportion of families with children used raisins; these families also used them more frequently. However, there has been a significant shift in the frequency of use of raisins. In the previous study, 71 percent of the homemakers said they served them once a month or more, contrasted with 63 percent in this study (tables 72 and 73 ).

${ }^{3}$ Hochstim, Esther S. Homemakers Appraise Citrus Products, Avocados, Dates and Raisins. U.S. Dept. Agr. Mktg. Res. Rpt. 243, June 1958. 


\section{APPENDIX}

\section{SAMPLE DESIGN}

The universe represented by the sample consists of homemakers residing in the 48 contiguous states. The homemaker is defined as the person in the household with major responsibility for purchasing and preparing food.

Since a full description of the sample design would take several pages and would be of little interest to most readers, only a few of the key characteristics of the sample will be given. It was a multistage probability sample with appropriate stratification at each level of selection and the use of probabilities proportional to size. The sample design and selection process contained a provision that each household in the population have an equal chance of being in the sample. In other words, the sample was selfweighted.

The three categories of communities for which data are presented in this report correspond to three major strata used in the design of the sample:

Large metropolitan areas: urbanized areas (as defined in the 1960 census) with a population of 1 million or more.

Small metropolitan areas: urbanized areas with a population of less than 1 million and all other urban places of 2,500 or more inhabitants.

Nonmetropolitan areas: towns of less than 2,500 and open country farm and nonfarm population.

\section{SAMPLING ERROR}

For unrestricted random samples, the standard deviation of a given proportion is calculated by the formula $\sqrt{\frac{p(1-p)}{n}}$ where ' $p$ ' represents the proportion responding, and ' $n$ ' represents the sample size. For the type of sample and questions involved in this survey the statistical efficiency is approximately equivalent to unrestricted random samples of half the size. Accordingly, approximate standard deviations of proportions in this study can be derived by using the formula $\sqrt{\frac{2 p(l-p)}{n}}$.

The magnitude of the sampling error varies with the size of the percentage being estimated and the number of cases upon which the percentage is based. The tabulation below presents approximations of sampling variability for selected percentages and numbers of cases.

\section{Standard error of estimated percentage}

Estimated

percentage
Number of respondents on which percentage is based

$\underline{100} \quad \underline{250} \quad \underline{500} \quad \underline{750} \quad \underline{1,000} \quad \underline{2,454}$

(in percentage points)

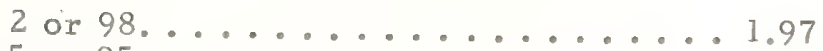

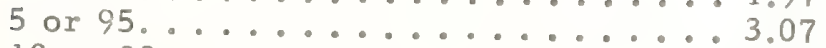
10 or $90 \ldots \ldots \ldots . . . \ldots 4.23$
25 or $75 \ldots \ldots \ldots \ldots . \ldots 6 . \ldots \ldots$
1.25
1.95
.89
2.68
1.38
.72
1.12
1.90
1.55
2.74
2.23
3.16
2.58
.40
.62
.86
1.24
4.46
7.04 


\section{TABLES}

The following detailed tables show the percentage distribution of homemakers who responded to the questions asked in this survey. Except for a few instances where similar questions have been grouped for ready comparison, the tables are arranged in questionnaire order.

The groupings according to size of community were described in the previous section on sample design.

The income categories represent total family income before taxes as reported by the homemakers interviewed. "Upper" includes annual incomes reported as $\$ 7,000$ or more, "middle" those from $\$ 4,000$ up to $\$ 7,000$, "lower" those under $\$ 4,000$.

Households are classified according to size as small (one or two members), medium (three or four members), and large (five or more members).

Cases classified by family composition, income, education, age, and other groupings may add to less than the total number of homemakers because of a few unclassified respondents. 


\begin{tabular}{|c|c|c|c|c|c|c|c|c|c|c|}
\hline $\begin{array}{l}n \\
0 \\
0 \\
0 \\
0 \\
0\end{array}$ & 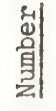 & $\begin{array}{l}\text { in } \\
\text { in } \\
\text { vi }\end{array}$ & 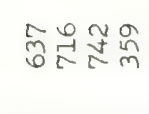 & 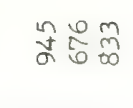 & 85: & 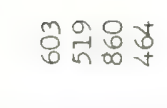 & 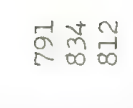 & 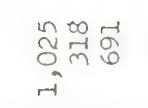 & 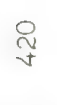 & 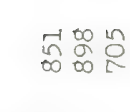 \\
\hline 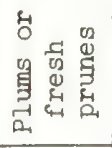 & $\begin{array}{l}\text { 명 } \\
0 \\
0 \\
0 \\
0.1\end{array}$ & $\mathscr{D}$ & న్రా & tôn & 요욤 & 윰ㄷㄷㄴ & 요ㅇㅛㅛ & $8 \stackrel{\circ}{1} \approx$ & R & 禹式象 \\
\hline 孚离 & 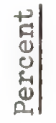 & $\stackrel{\sim}{\sim}$ & 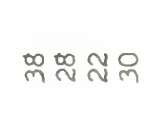 & 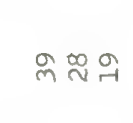 & $\stackrel{\infty}{\infty} \stackrel{\bullet}{\sim}$ & 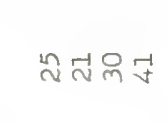 & $\stackrel{\sim}{\sim} \sim \bar{m}$ & 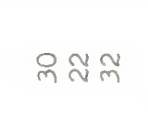 & $\stackrel{\infty}{\sim}$ & ని શ $\stackrel{\infty}{\sim}$ \\
\hline 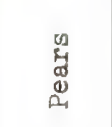 & 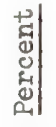 & $+\infty$ & -10 & 气。용 & શธิ์ & 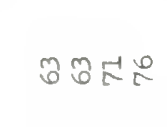 & $\stackrel{\circ}{\llcorner}:$ & 요용 & 8 & 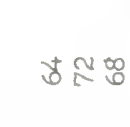 \\
\hline 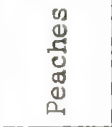 & $\begin{array}{l}\text { a } \\
0 \\
0 \\
0 \\
0 \\
0.1\end{array}$ & $\infty$ & న + & $\begin{array}{ccc}5 \\
\infty \\
\infty\end{array}$ & 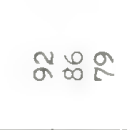 & 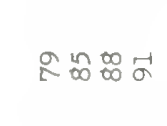 & ఐ & జూ & న్ & $\begin{array}{cc}-1 \\
\infty \\
\infty \\
\infty & \infty \\
\infty & \infty \\
\infty\end{array}$ \\
\hline 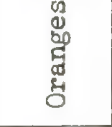 & \begin{tabular}{l|} 
ta \\
0 \\
0 \\
0 \\
0
\end{tabular} & 8 & హై ๙ૂळ & $\begin{array}{c}\infty \\
\infty \\
\infty \\
\infty \\
\infty\end{array}$ & 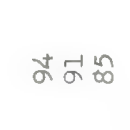 & 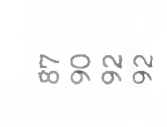 & 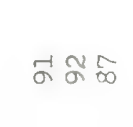 & ๓ & 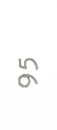 & ๓ิ ตू \\
\hline 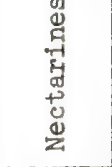 & 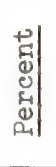 & $\stackrel{g}{m}$ & ఫฺ & ㅇํำ & బี & 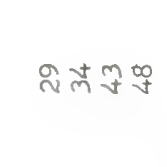 & $\hat{m} \underset{v}{m}$ & ติตัตั & $\dot{m}$ & से \\
\hline 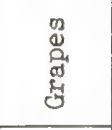 & \begin{tabular}{l|l} 
& \\
0 & \\
0 \\
0 \\
0 \\
0.1
\end{tabular} & ळ & 옹오 & 응요요 & ॠून्म & 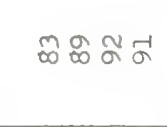 & 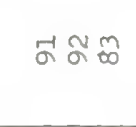 & ๓ & 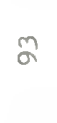 & - \\
\hline 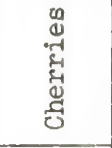 & $\begin{array}{l}\text { a } \\
0 \\
0 \\
0 \\
0 \\
0\end{array}$ & $\stackrel{\infty}{+}$ & ํำ & 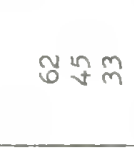 & 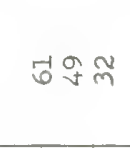 & 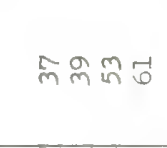 & 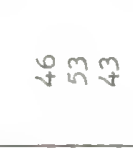 & 斗翼 & $\stackrel{\infty}{+}$ & trit \\
\hline 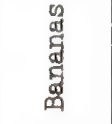 & $\begin{array}{l}\text { त्. } \\
0 \\
0 \\
0 \\
0\end{array}$ & 2 & 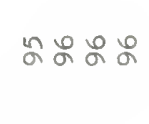 & สัะั & ஃ๙ & วัธัธ & ลิธู & ส้รล & \% & హ் \\
\hline 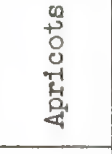 & \begin{tabular}{l|}
0 \\
0 \\
0 \\
0 \\
0 \\
0
\end{tabular} & $\widetilde{N}$ & ฝે웜ำ & શิ શิ & 우요 & 怘承 & ำ & ฟิํำ & $\stackrel{\infty}{\infty}$ & $\underset{N}{N}$ \\
\hline 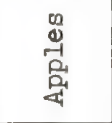 & \begin{tabular}{l|} 
a \\
$\vdots$ \\
0 \\
0 \\
0 \\
0
\end{tabular} & \% & ぶすัญ。 & ผูะฒ & 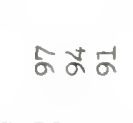 & タะஃু & 동용요 & 옹요 & s & ๙ิธ人์ \\
\hline 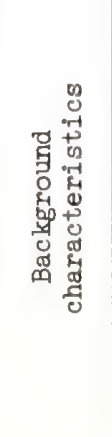 & & 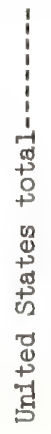 & 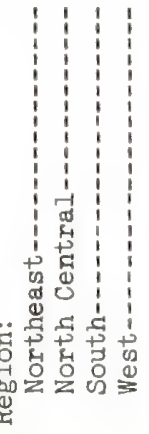 & 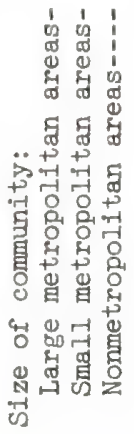 & 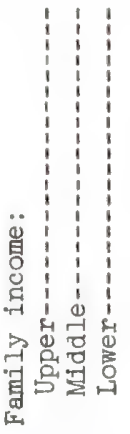 & 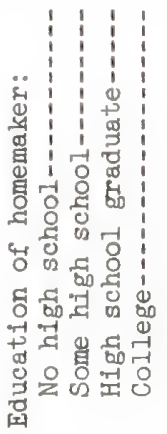 & 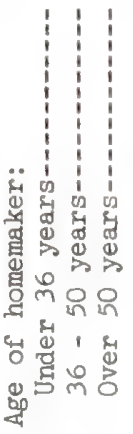 & 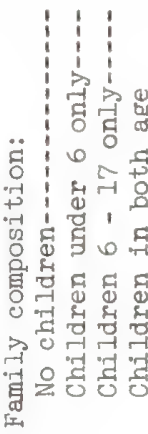 & 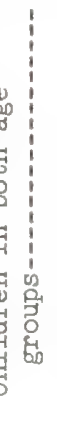 & 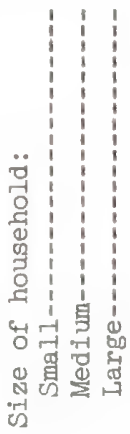 \\
\hline
\end{tabular}




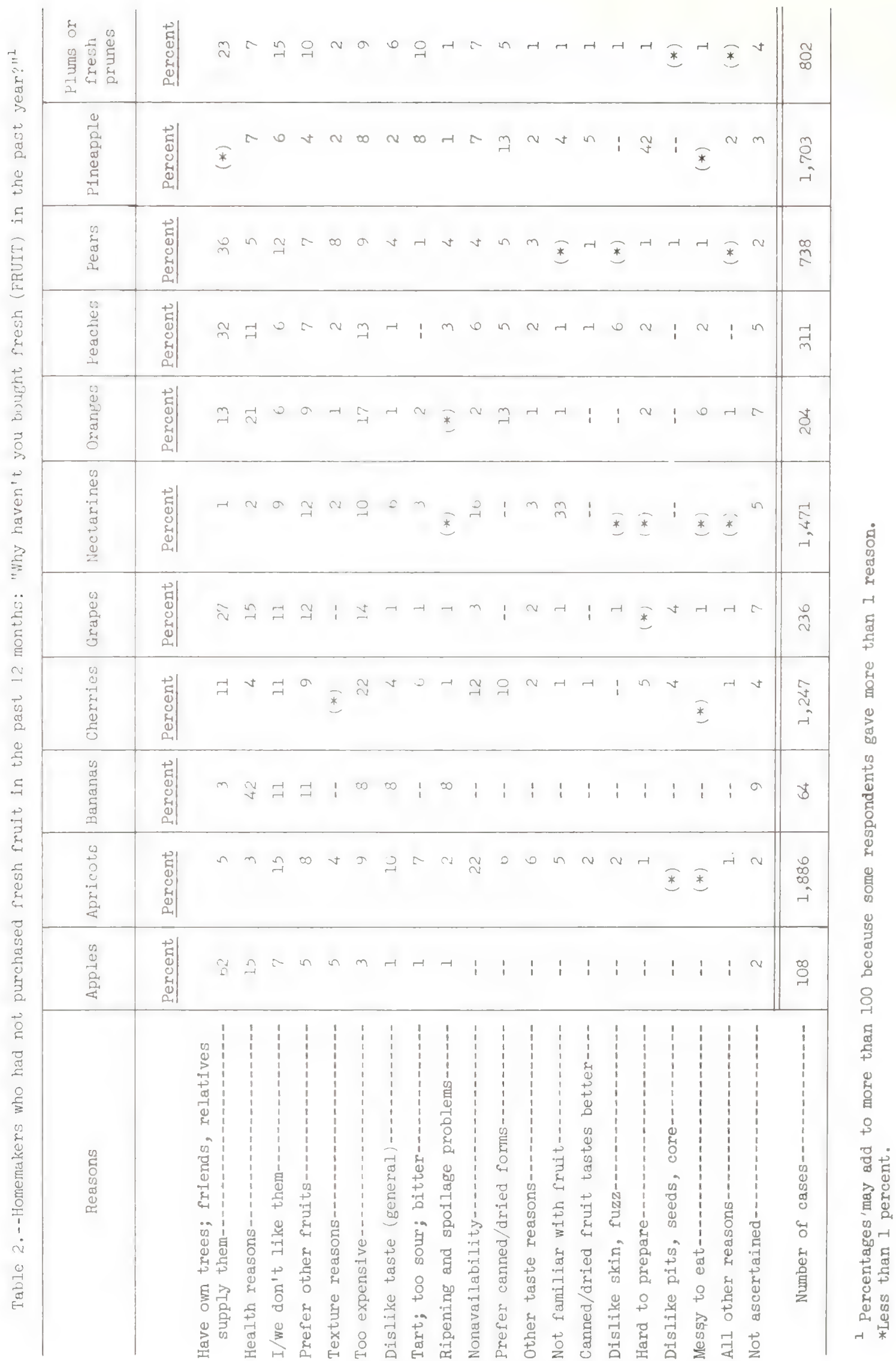




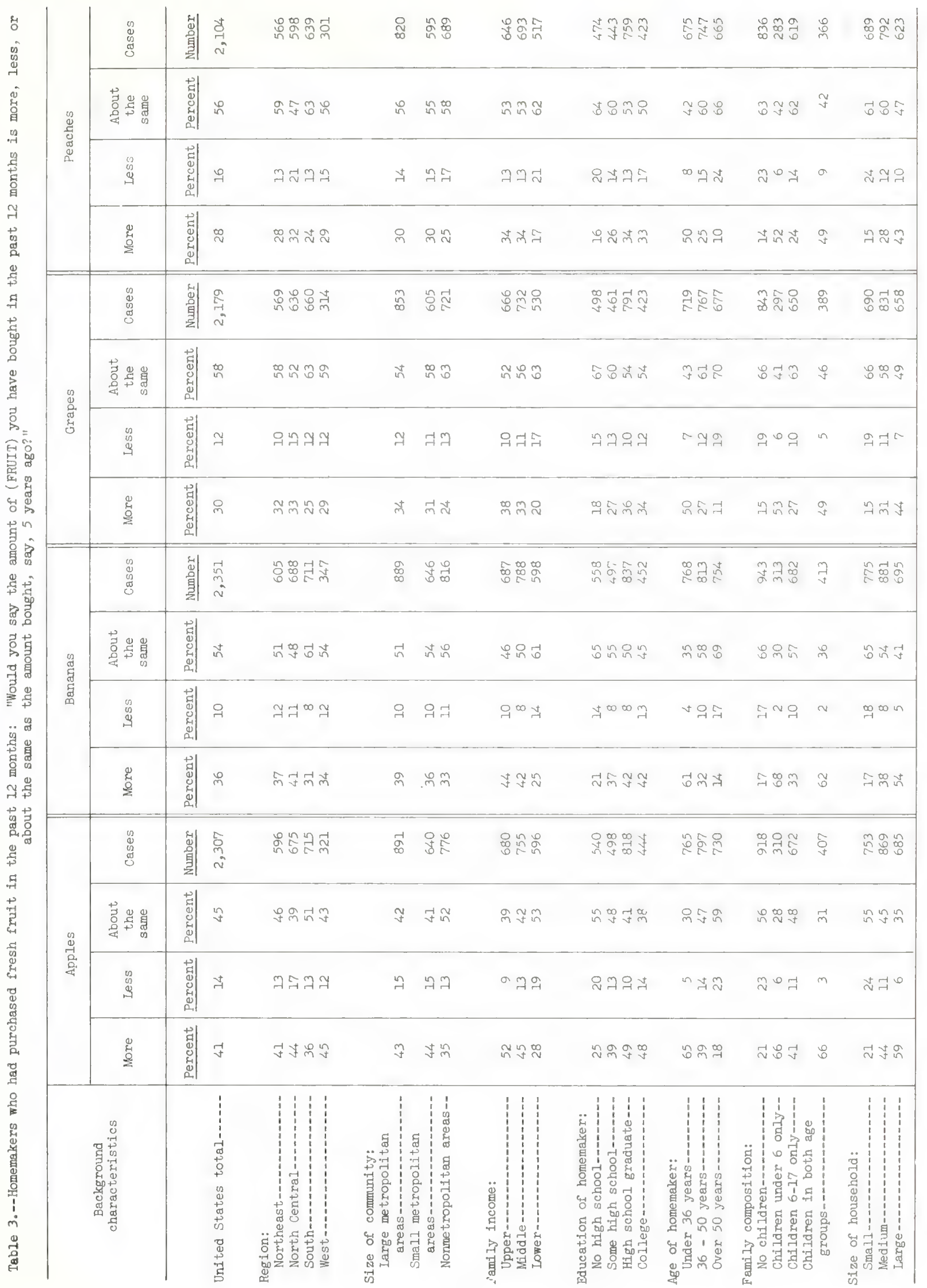


Table 4.--Homemakers who indicated they had purchased more (frult) in the past year than 5 years ago: "Why are you buying more (FRUIT) now?"1

\section{Rearons}

\begin{tabular}{|c|c|c|c}
\hline Apples & Bananas & Grapes & Feaches \\
\hline Percent & Percent & Percent & Percent \\
\hline 42 & 41 & 42 & 42 \\
39 & 39 & 36 & 32 \\
9 & 9 & 7 & 5 \\
7 & 2 & 1 & 12 \\
6 & 8 & 6 & 5 \\
5 & 5 & 8 & 6 \\
4 & 2 & 5 & 4 \\
3 & 7 & 1 & 3 \\
3 & 6 & 2 & 3 \\
2 & 2 & 2 & 2 \\
2 & 1 & 3 & 1 \\
2 & 1 & 1 & 2 \\
1 & 2 & 3 & 1 \\
1 & 1 & 2 & 2 \\
1 & 1 & 1 & $(*)$ \\
1 & $(*)$ & 1 & 1 \\
2 & 1 & 1 & 2 \\
1 & 1 & 1 & 2 \\
\hline \hline 940 & 846 & 648 & 590 \\
\hline 1 & & & 1 \\
\hline
\end{tabular}

Family is larger

Children are older, old enough to eat them-

Use them for packed lunches, snacks

We baike/can/freeze more-

Health reasons

We prefer them, eat more of them-

Availability

I/we have found new/more uses for them-

They are less expensive

They are a substitute for sweets

Iike the taste--.-

Can afford them now-

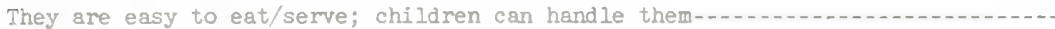
Better quality (general)

We entertain more-

They are iuivier-

All other reasons

Not ascertained

Number of cases

1 Percentages may add to more than 100 because some respondents gave more than 1 reason.

* Iess than 1 percent.

Tabie 5.--Homemakers who indicated they had purchased less (frult) in the past year than 5 years ago: "Why are you buying less (FRUIT) now?" 1

\begin{tabular}{|c|c|c|c|c|}
\hline & Percent & Percent & Percent & Percent \\
\hline They're too expensive-1...- & 9 & 7 & 12 & 13 \\
\hline We are eating less; don't care for them as mich-.......- & 8 & 9 & 12 & 6 \\
\hline Have own trees; friends, relatives supply them & 6 & -- & 5 & 4 \\
\hline 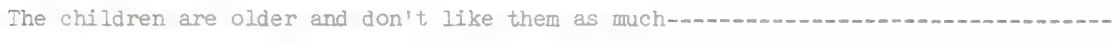 & 4 & 9 & 3 & 2 \\
\hline 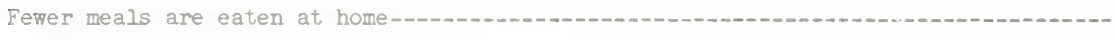 & 4 & 4 & 3 & 3 \\
\hline They have fewer uses.................. & 2 & 4 & 3 & 1 \\
\hline We buy them canned-......... & $(*)$ & $(*)$ & -- & 4 \\
\hline All other reasons -..............- & 1 & $(*)$ & 1 & $(*)$ \\
\hline Not ascertained-1. & $(*)$ & 1 & 3 & 2 \\
\hline Number of cases-1.- & 321 & 245 & 266 & 326 \\
\hline
\end{tabular}

1 percentages may add to more than 100 because some respondents gave more than 1 reason.

* Iess than 1 percent. 
Table 6.--Homemakers who had purchased fresh fruit in the past 12 months: "During which season of the year do you buy the greatest amount of fresh (FRUITS)? In what other seasons do you buy fresh (FRUIT)?"

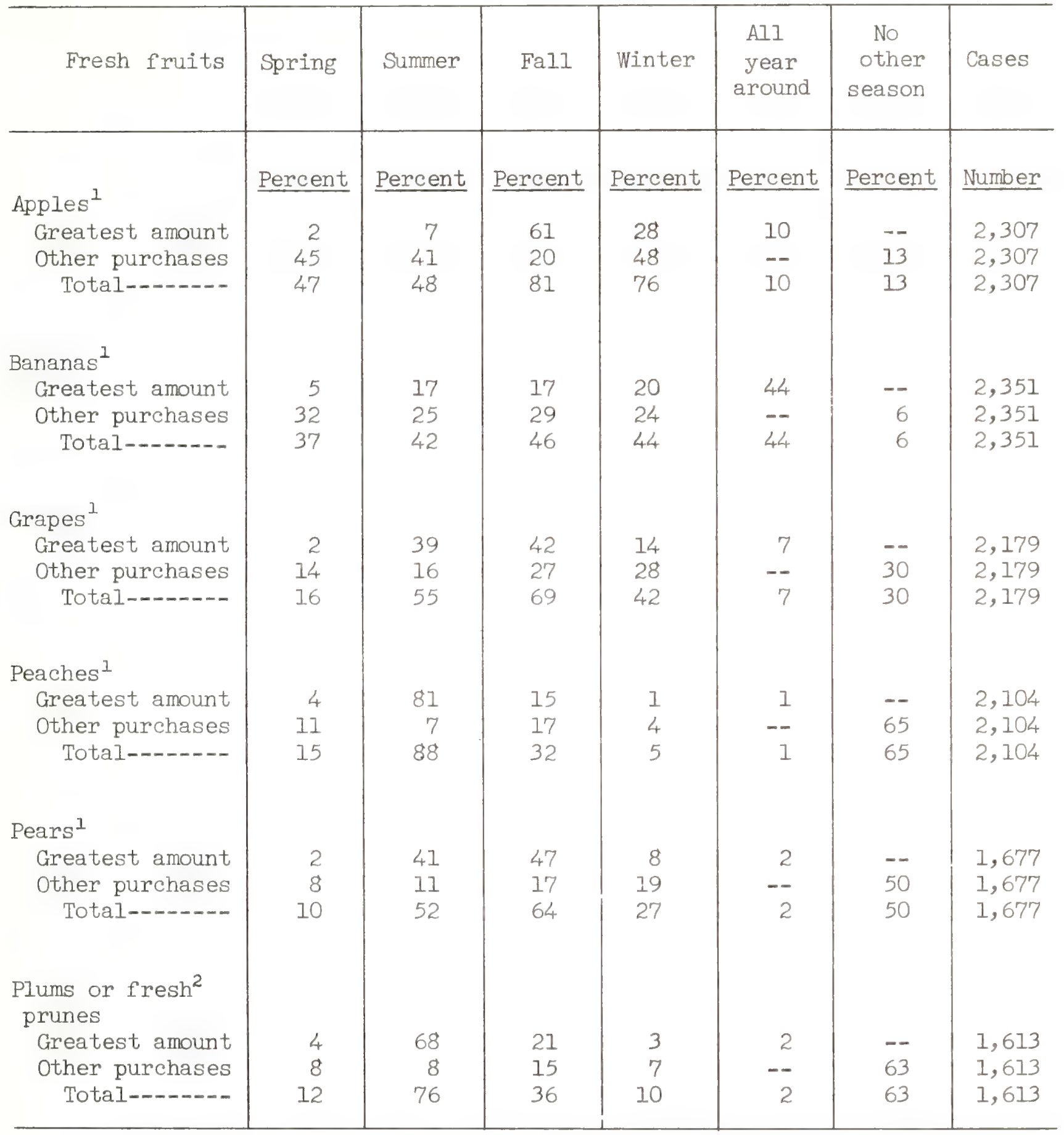

1 Percentages may add to more than 100 because some respondents had purchased fruit in more than one season.

? Percentages do not add to 100 because some respondents did not, indicate what season they purchased the "greatest amount" in. 
Table 7.--Homemakers who had purchased fresh apples in the past 12 months: "What amount of fresh apples do you usually buy at a time during the season when greatest amount purchased? About how often do you buy apples in this quantity during that season?"I

\begin{tabular}{|c|c|c|c|c|c|}
\hline \multirow{2}{*}{$\begin{array}{l}\text { Background } \\
\text { characteristics }\end{array}$} & \multicolumn{4}{|c|}{ Apple purchase levels ${ }^{2}$} & \multirow{2}{*}{ Cases } \\
\hline & High & Medium & Low & No answer & \\
\hline & Percent & Percent & Percent & Percent & Number \\
\hline United States total- & 32 & 42 & 24 & 2 & 2,307 \\
\hline \multicolumn{6}{|l|}{ Region: } \\
\hline Northeast-_-n & 31 & 45 & 22 & 2 & 596 \\
\hline North Central-- & 33 & 40 & 26 & 1 & 675 \\
\hline 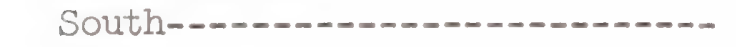 & 31 & 42 & 25 & 2 & 715 \\
\hline 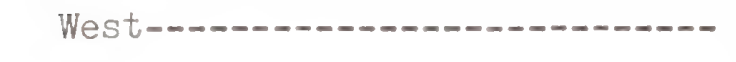 & 32 & 42 & 23 & 3 & 321 \\
\hline \multicolumn{6}{|l|}{ Size of community: } \\
\hline Large metropolitan areas--.---- & 27 & 46 & 26 & 1 & 891 \\
\hline Small metropolitan areas--.---- & 33 & 41 & 24 & 2 & 640 \\
\hline Nonmetropolitan areas-_-_-..--- & 35 & 39 & 24 & 2 & 776 \\
\hline \multicolumn{6}{|l|}{ Family income: } \\
\hline 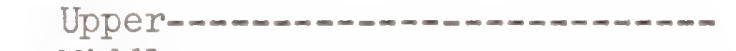 & 36 & 45 & 18 & 1 & 680 \\
\hline 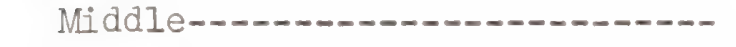 & 33 & 43 & 22 & 2 & 755 \\
\hline Lower--1-n-_- & 26 & 38 & 33 & 3 & 596 \\
\hline \multicolumn{6}{|l|}{ Age of homemaker: } \\
\hline 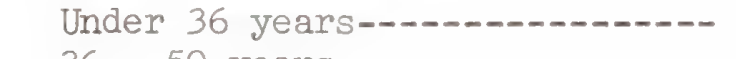 & 31 & 45 & 23 & 1 & 765 \\
\hline 36 - 50 years-n- & 38 & 42 & 19 & 1 & 797 \\
\hline 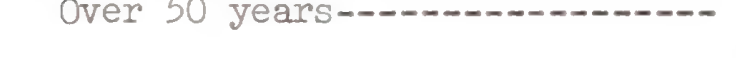 & & 41 & & 2 & \\
\hline \multicolumn{6}{|l|}{ Family composition: } \\
\hline No children--- & 21 & $4 I$ & 35 & 3 & 918 \\
\hline Children under 6 only-........ & 23 & 46 & 30 & 1 & 310 \\
\hline Children 6-17 only---------- & 39 & 45 & 15 & 1 & 672 \\
\hline Children in both age groups---- & 49 & 38 & 12 & 1 & 407 \\
\hline \multicolumn{6}{|l|}{ Size of household: } \\
\hline Small-n...- & 18 & 40 & 39 & 3 & 753 \\
\hline Medium-1-non & 31 & 47 & 21 & 1 & 869 \\
\hline 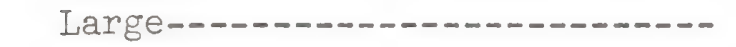 & 47 & 39 & 13 & 1 & 685 \\
\hline
\end{tabular}

1 The purchase levels are approximate, since they are based on homemakers' memories of the amounts they normally buy at a time and on the amounts they buy each time. Also the official dates of the seasons were not mentioned to the homemakers, who therefore made their own interpretations of them.

2 The total amounts homemakers reported thay had purchased were grouped roughly into thirds. 
Table 8.--Homemakers who had purchased fresh bananas in the past 12 months: "What amount of fresh bananas do you usually buy at a time during the season when greatest amount purchased? About how often do you buy bananas in this quantity during that season?"I

\begin{tabular}{|c|c|c|c|c|c|}
\hline \multirow{2}{*}{$\begin{array}{l}\text { Background } \\
\text { characteristics }\end{array}$} & \multicolumn{5}{|c|}{ Banana purchase levels } \\
\hline & High & Medium & Low & $\begin{array}{c}\text { No } \\
\text { answer }\end{array}$ & Cases \\
\hline & Percent & Percent & Percent & Percent & Number \\
\hline United States total- & 33 & 34 & 31 & 2 & 2,351 \\
\hline \multicolumn{6}{|l|}{ Region: } \\
\hline Northeast_- & 33 & 37 & 28 & 2 & 605 \\
\hline North Central-_- & 32 & 34 & 32 & 2 & 688 \\
\hline 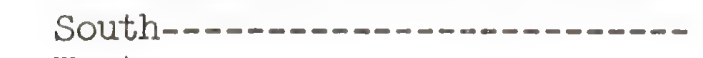 & 32 & 35 & 32 & 1 & 711 \\
\hline 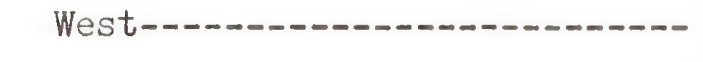 & 35 & 29 & 32 & 4 & 347 \\
\hline \multicolumn{6}{|l|}{ Size of community: } \\
\hline Large metropolitan areas-..--- & 35 & 35 & 28 & 2 & 889 \\
\hline Small metropolitan areas---.-- & 33 & 33 & 31 & 3 & 646 \\
\hline Nonmetropolitan areas--.-.---- & 29 & 34 & 35 & 2 & 816 \\
\hline \multicolumn{6}{|l|}{ Family income: } \\
\hline 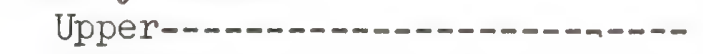 & 36 & 35 & 27 & 2 & 687 \\
\hline 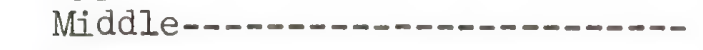 & 35 & 35 & 28 & 2 & 788 \\
\hline 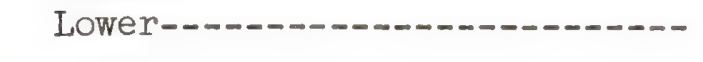 & 27 & 33 & 38 & 2 & 598 \\
\hline \multicolumn{6}{|l|}{ Age of homemaker: } \\
\hline Under 36 years & 36 & 34 & 28 & 2 & 768 \\
\hline 36 - 50 years-n- & 39 & 32 & 28 & 1 & 813 \\
\hline Over 50 years--_--_- & 23 & 36 & 38 & 3 & 754 \\
\hline \multicolumn{6}{|l|}{ Family composition: } \\
\hline No children--no- & 19 & 35 & 43 & 3 & 943 \\
\hline Children under 6 only-...--- & 30 & 38 & 31 & 1 & 313 \\
\hline 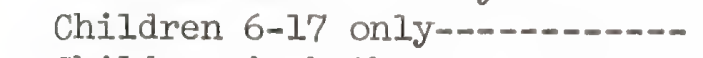 & 41 & 32 & 25 & 2 & 682 \\
\hline Children in both age groups--- & 52 & 30 & 16 & 2 & 413 \\
\hline \multicolumn{6}{|l|}{ Size of household: } \\
\hline 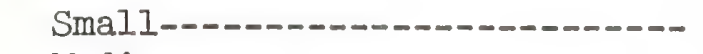 & 16 & 36 & 45 & 3 & 775 \\
\hline 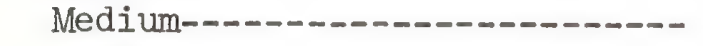 & 33 & 36 & 30 & 1 & 881 \\
\hline 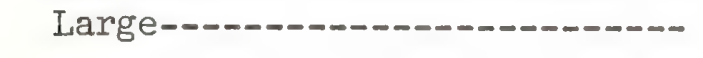 & 50 & 30 & 18 & 2 & 695 \\
\hline
\end{tabular}

1 See footnotes to table 7. 
Table 9.--Homemakers who had purchased fresh grapes in the past 12 months: "What amount of fresh grapes do you usually buy at a time during the season when greatest amount purchased? About how often do you buy grapes in this quantity during that season?"I

\begin{tabular}{|c|c|c|c|c|c|}
\hline \multirow{2}{*}{$\begin{array}{l}\text { Background } \\
\text { characteristics }\end{array}$} & \multicolumn{4}{|c|}{ Grape purchase levels } & \multirow[b]{2}{*}{ Cases } \\
\hline & High & Medium & Low & $\begin{array}{c}\text { No } \\
\text { answer }\end{array}$ & \\
\hline & Percent & Percent & Percent & Percent & Number \\
\hline United States total & 36 & 31 & 30 & 3 & 2,179 \\
\hline \multicolumn{6}{|l|}{ Region: } \\
\hline Northeast-_. & 44 & 30 & 24 & 2 & 569 \\
\hline North Central-_- & 31 & 34 & 33 & 2 & 636 \\
\hline 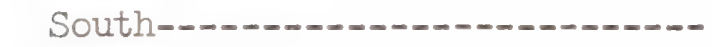 & 31 & 29 & 37 & 3 & 660 \\
\hline West--non & 48 & 27 & 21 & 4 & 314 \\
\hline \multicolumn{6}{|l|}{ Size of community: } \\
\hline Large metropolitan areas--.--.-- & 44 & 31 & 23 & 2 & 853 \\
\hline Small metropolitan areas---.--- & 36 & 32 & 30 & 2 & 605 \\
\hline Nonmetropolitan areas-.--.-.--- & 28 & 28 & 39 & 5 & 721 \\
\hline \multicolumn{6}{|l|}{ Family income: } \\
\hline Upper-n...... & 44 & 32 & 23 & 1 & 666 \\
\hline 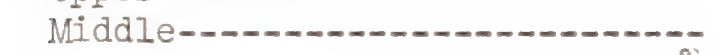 & 35 & 30 & 32 & 3 & 732 \\
\hline 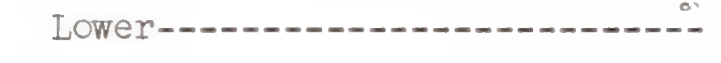 & 29 & 29 & 38 & 4 & 530 \\
\hline \multicolumn{6}{|l|}{ Age of homemaker: } \\
\hline Under 36 years----.--- & 37 & 31 & 30 & 2 & 719 \\
\hline 36 - 50 years & 41 & 30 & 27 & 2 & 767 \\
\hline Over 50 years-n-..- & 32 & 31 & 33 & 4 & 677 \\
\hline \multicolumn{6}{|l|}{ Family composition: } \\
\hline 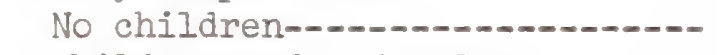 & 30 & 31 & 36 & 3 & 843 \\
\hline Children under 6 only--.--.---. & 33 & 32 & 33 & 2 & 297 \\
\hline Children 6-17 only---------- & 42 & 31 & 25 & 2 & 650 \\
\hline Children in both age groups---- & 45 & 28 & 24 & 3 & 389 \\
\hline \multicolumn{6}{|l|}{ Size of household: } \\
\hline Small-_-_- & 28 & 33 & 36 & 3 & 690 \\
\hline 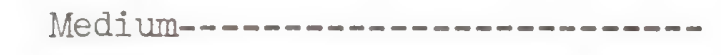 & 37 & 31 & 30 & 2 & 831 \\
\hline Large------ & 45 & 27 & 25 & 3 & 658 \\
\hline
\end{tabular}

I See footnotes to table 7 . 
Table 10.--Homemakers who had purchased fresh peaches in the past 12 months: "What amount of fresh peaches do you usually buy at a time during the season when greatest amount purchased? About how often do you buy peaches in this quantity during that season?" ${ }^{1}$

\begin{tabular}{|c|c|c|c|c|c|}
\hline \multirow{2}{*}{$\begin{array}{l}\text { Background } \\
\text { characteristics }\end{array}$} & \multicolumn{4}{|c|}{ Peach purchase levels } & \multirow[b]{2}{*}{ Cases } \\
\hline & High & Medium & Low & $\begin{array}{c}\text { No } \\
\text { answer }\end{array}$ & \\
\hline & Percent & Percent & Percent & Percent & Number \\
\hline 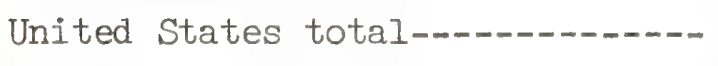 & 25 & 41 & 31 & 3 & 2,104 \\
\hline $\begin{array}{l}\text { Region: } \\
\text { Northeast } \\
\text { North Central } \\
\text { South } \\
\text { West- }\end{array}$ & $\begin{array}{l}22 \\
27 \\
28 \\
21\end{array}$ & $\begin{array}{l}47 \\
40 \\
39 \\
38\end{array}$ & $\begin{array}{l}29 \\
31 \\
29 \\
36\end{array}$ & $\begin{array}{l}2 \\
2 \\
4 \\
5\end{array}$ & $\begin{array}{l}566 \\
598 \\
639 \\
301\end{array}$ \\
\hline 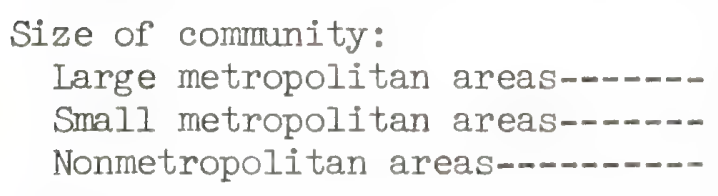 & $\begin{array}{l}23 \\
25 \\
28\end{array}$ & $\begin{array}{l}45 \\
40 \\
38\end{array}$ & $\begin{array}{l}30 \\
32 \\
29\end{array}$ & $\begin{array}{l}2 \\
3 \\
5\end{array}$ & $\begin{array}{l}820 \\
595 \\
689\end{array}$ \\
\hline $\begin{array}{l}\text { Family income: } \\
\text { Upper } \\
\text { Middle } \\
\text { Lower- }\end{array}$ & $\begin{array}{l}25 \\
26 \\
24\end{array}$ & $\begin{array}{l}48 \\
39 \\
38\end{array}$ & $\begin{array}{l}26 \\
31 \\
35\end{array}$ & $\begin{array}{l}1 \\
4 \\
3\end{array}$ & $\begin{array}{l}646 \\
693 \\
517\end{array}$ \\
\hline $\begin{array}{l}\text { Age of homemaker: } \\
\text { Under } 36 \text { years } \\
36 \text { - } 50 \text { years } \\
\text { Over } 50 \text { years. }\end{array}$ & $\begin{array}{l}22 \\
27 \\
26\end{array}$ & $\begin{array}{l}39 \\
46 \\
39\end{array}$ & $\begin{array}{l}36 \\
24 \\
31\end{array}$ & $\begin{array}{l}3 \\
3 \\
4\end{array}$ & $\begin{array}{l}675 \\
747 \\
665\end{array}$ \\
\hline $\begin{array}{l}\text { Family composition: } \\
\text { No children-ar } \\
\text { Children under } 6 \text { only- } \\
\text { Children } 6-17 \text { only- } \\
\text { Children in both age groups--- }\end{array}$ & $\begin{array}{l}21 \\
17 \\
31 \\
33\end{array}$ & $\begin{array}{l}42 \\
39 \\
42 \\
42\end{array}$ & $\begin{array}{l}34 \\
41 \\
24 \\
23\end{array}$ & $\begin{array}{l}3 \\
3 \\
3 \\
2\end{array}$ & $\begin{array}{l}836 \\
283 \\
619 \\
366\end{array}$ \\
\hline $\begin{array}{l}\text { Size of household: } \\
\text { Small } \\
\text { Medium- } \\
\text { Large- }\end{array}$ & $\begin{array}{l}18 \\
25 \\
34\end{array}$ & $\begin{array}{l}41 \\
42 \\
41\end{array}$ & $\begin{array}{l}38 \\
30 \\
22\end{array}$ & $\begin{array}{l}3 \\
3 \\
3\end{array}$ & $\begin{array}{l}689 \\
792 \\
623\end{array}$ \\
\hline
\end{tabular}

1 See footnotes to table 7. 
Table 11.--Homemakers who had purchased fresh pears in the past 12 months: "What amount of fresh pears do you usually buy at a time during the season when greatest amount purchased? About how often do you buy pears in this quantity during that season?" 1

\begin{tabular}{|c|c|c|c|c|c|}
\hline \multirow{2}{*}{$\begin{array}{c}\text { Background } \\
\text { characteristics }\end{array}$} & \multicolumn{4}{|c|}{ Pear purchase levels } & \multirow{2}{*}{ Cases } \\
\hline & High & Medium & Low & $\begin{array}{c}\text { No } \\
\text { answer }\end{array}$ & \\
\hline & Percent & Percent & Percent & Percent & Number \\
\hline United States total & 35 & 28 & 31 & 6 & 1,677 \\
\hline \multicolumn{6}{|l|}{ Region: } \\
\hline Northeast_...... & 39 & 29 & 30 & 2 & 518 \\
\hline North Central & 39 & 29 & 28 & 4 & 448 \\
\hline 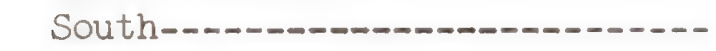 & 28 & 27 & 36 & 9 & 462 \\
\hline 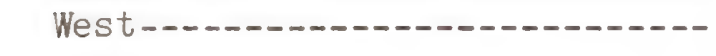 & 36 & 26 & 29 & 9 & 249 \\
\hline \multicolumn{6}{|l|}{ Size of community: } \\
\hline Large metropolitan areas...-- & 37 & 31 & 29 & 3 & 729 \\
\hline Small metropolitan areas-....-- & 34 & 27 & 35 & 4 & 465 \\
\hline Nonmetropolitan areas.......... & 35 & 24 & 30 & 11 & 483 \\
\hline \multicolumn{6}{|l|}{ Family income: } \\
\hline Upper---n- & 38 & 31 & 28 & 3 & 551 \\
\hline Middle $\ldots \ldots \ldots \ldots \ldots$ & 36 & 28 & 31 & 5 & 543 \\
\hline Lower-n- & 34 & 25 & 33 & 8 & 396 \\
\hline \multicolumn{6}{|l|}{ Age of homemaker: } \\
\hline Under 36 years & 33 & 28 & 35 & 4 & 519 \\
\hline 36 - 50 years & 38 & 30 & 27 & 5 & 608 \\
\hline Over 50 years $\ldots$ & 36 & 26 & 31 & 7 & 535 \\
\hline \multicolumn{6}{|l|}{ Family composition: } \\
\hline 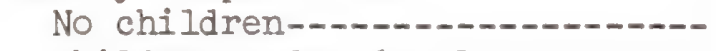 & 32 & 27 & 35 & 6 & 675 \\
\hline Children under 6 only-n- & 31 & 28 & 37 & 4 & 216 \\
\hline Children 6-17 only & 40 & 28 & 25 & 7 & 509 \\
\hline Children in both age groups---- & 39 & 29 & 27 & 5 & 277 \\
\hline \multicolumn{6}{|l|}{ Size of household: } \\
\hline Small-m-n-m-n-m-n-m-n-m-n-m & 30 & 26 & 38 & 6 & 548 \\
\hline Medium--n-n-ne-n & 36 & 29 & 30 & 5 & 647 \\
\hline Large & 42 & 29 & 24 & 5 & 482 \\
\hline
\end{tabular}

1 See footnotes to table 7. 
Table 12.--Homemakers who had purchased fresh plums or prunes in the past 12 months: "What amount of fresh plums or fresh prunes do you usually buy at a time during the season when greatest amount purchased? About how of ten do you buy plums or fresh prunes in the quantity during that season?"I

\begin{tabular}{|c|c|c|c|c|c|}
\hline \multirow{2}{*}{$\begin{array}{c}\text { Background } \\
\text { characteristics }\end{array}$} & \multicolumn{5}{|c|}{ Plums or fresh prune purchase levels } \\
\hline & High & Medium & Low & $\begin{array}{c}\text { No } \\
\text { answer }\end{array}$ & Cases \\
\hline & Percent & Percent & Percent & Percent & Number \\
\hline United States total-n-..- & 36 & 36 & 21 & 7 & 1,613 \\
\hline \multicolumn{6}{|l|}{ Region: } \\
\hline Northeast $\ldots \ldots-\ldots \ldots$ & 44 & 35 & 18 & 3 & 524 \\
\hline North Central-n-.-- & 35 & 36 & 22 & 7 & 482 \\
\hline South-n-n-n-1-n- & 22 & 39 & 28 & 11 & 363 \\
\hline West-n-n- & 39 & 36 & 14 & 11 & 244 \\
\hline \multicolumn{6}{|l|}{ Size of community: } \\
\hline Large metropolitan areas...... & 43 & 37 & 15 & 5 & 736 \\
\hline Small metropolitan areas ...... & 31 & 38 & 25 & 6 & 451 \\
\hline Nonmetropolitan areas-_-_- & 28 & 33 & 27 & 12 & 426 \\
\hline \multicolumn{6}{|l|}{ Family income: } \\
\hline Upper-n-n-n-n-n-n- & 43 & 34 & 18 & 5 & 556 \\
\hline Middle & 35 & 38 & 20 & 7 & 547 \\
\hline Lower-n-n- & 28 & 39 & 23 & 10 & 337 \\
\hline \multicolumn{6}{|l|}{ Age of homemaker: } \\
\hline Under 36 years & 37 & 33 & 24 & 6 & 526 \\
\hline 36 - 50 years $\ldots$ & 39 & 37 & 19 & 5 & 593 \\
\hline Over 50 years & 29 & 40 & 21 & 10 & 480 \\
\hline \multicolumn{6}{|l|}{ Family composition: } \\
\hline No children-...... & 28 & 40 & 24 & 8 & 613 \\
\hline Children under 6 only & 35 & 34 & 26 & 5 & 209 \\
\hline Children 6-17 only-n. & 41 & 37 & 15 & 7 & 496 \\
\hline Children in both age groups-.-- & 42 & 31 & 21 & 6 & 295 \\
\hline \multicolumn{6}{|l|}{ Size of household: } \\
\hline Small-n- & 26 & 40 & 26 & 8 & 497 \\
\hline 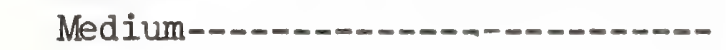 & 37 & 37 & 20 & 6 & 636 \\
\hline Large-n. & 44 & 32 & 17 & 7 & 480 \\
\hline
\end{tabular}

1 See footnotes to table 7. 
Table 13.--Homemakers' fresh apple purchase levels of, analyzed by their other fruit purchase levels

Other fresh fruit purchase levels

\section{Bananas}

High-.

Medium

Low-

Not ascertained

Number of cases..........................

Grapes

High-

Medium-

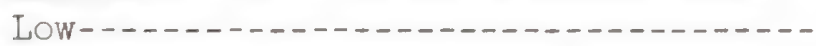

Not ascertained--_-_-_-_-_...--

Number of cases-_._._._..............

Peaches

High-

Medium-

Low-

Not ascertained-........................

Number of cases-1.-...-............

\begin{tabular}{|c|c|c|}
\hline \multicolumn{3}{|c|}{ Apple purchase levels } \\
\hline High & Medium & Low \\
\hline Percent & Percent & Percent \\
\hline 54 & 30 & 13 \\
\hline 28 & 41 & 31 \\
\hline 17 & 28 & 54 \\
\hline 1 & 1 & 2 \\
\hline 720 & 958 & 542 \\
\hline Percent & Percent & Percent \\
\hline 50 & 40 & 14 \\
\hline 28 & 31 & 34 \\
\hline 20 & 27 & 49 \\
\hline 2 & 2 & 3 \\
\hline 680 & 912 & 494 \\
\hline Percent & Percent & Percent \\
\hline 43 & 21 & 9 \\
\hline 38 & 49 & 32 \\
\hline 16 & 28 & 56 \\
\hline 3 & 2 & 3 \\
\hline 651 & 892 & 476 \\
\hline Percent & Percent & Percent \\
\hline 49 & 37 & 14 \\
\hline 25 & 32 & 28 \\
\hline 23 & 28 & 50 \\
\hline 3 & 3 & 8 \\
\hline 542 & 733 & 345 \\
\hline Percent & Percent & Percent \\
\hline 47 & 38 & 15 \\
\hline 31 & 39 & 42 \\
\hline 17 & 18 & 34 \\
\hline 5 & 5 & 9 \\
\hline 525 & 692 & 338 \\
\hline
\end{tabular}

Plums, fresh prunes

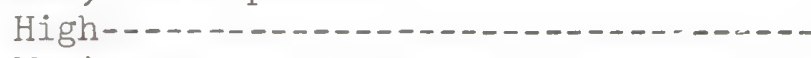

Medium-1.-.

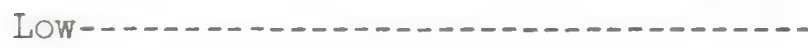

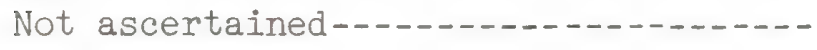

Number of cases..................... 
Table 14.--Homemakers who had purchased fresh fruit in the past 12 months: "Suppose you were the manager of a store and wanted to get people to buy more of these fresh fruits. What ways can you think of that might get your customers to buy more?"I

United States total

Display high quality fresh fruit_...

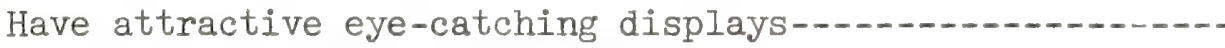

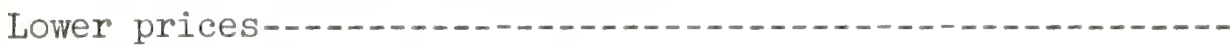

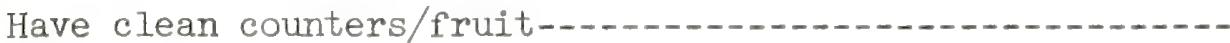

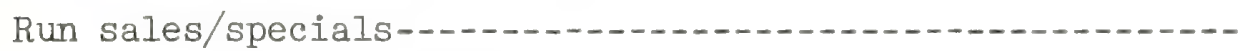
AdvertisePut in prominent position

Display loose fruit-

Display, stack fruit neatly-

Provide recipes-........

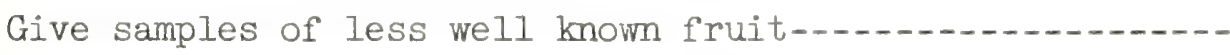

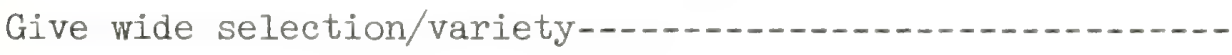

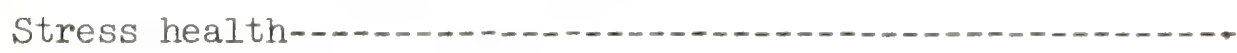

Prepackage the fruit_-....

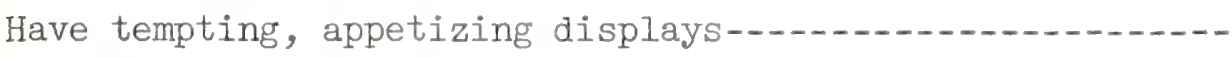

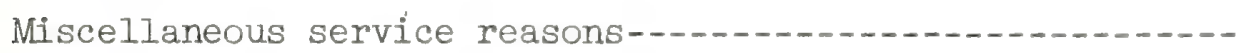

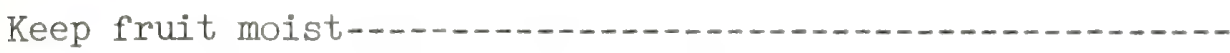

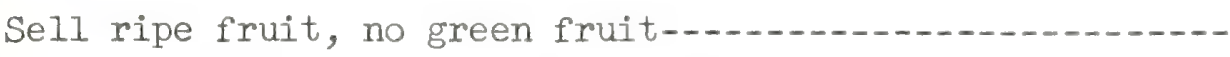

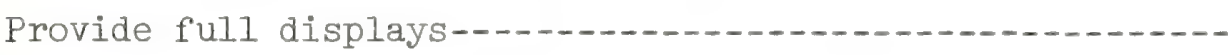

Don't allow handling

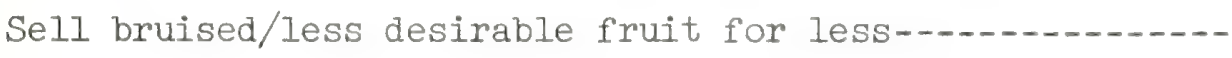

All other suggestions-.......

No suggestions -

Not ascertained-

Number of cases

\section{Percent}

2,415

1 Percentages add to more than 100 because some respondents gave more than one suggestion. 
Table 15.-Homemakers who had purchased fresh fruit in the past 12 months: "What kind of fresh fruit did you buy last? ${ }^{* 1}$

\begin{tabular}{|c|c|c|c|c|c|c|c|c|c|}
\hline $\begin{array}{c}\text { Background } \\
\text { characteristics }\end{array}$ & Apples & Bananas & Oranges & Grapes & Grapefruit & Tangerines & Pears & $\begin{array}{l}\text { Ald } \\
\text { other }^{2}\end{array}$ & Cases $^{3}$ \\
\hline & Percent & Perient & Perient & Percent & Percent & Percent & Percent & Percent & Number \\
\hline United States total--.-- & 61 & 57 & 28 & 20 & 8 & 8 & 7 & 5 & 2,410 \\
\hline 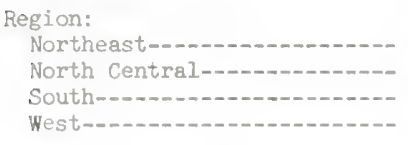 & $\begin{array}{l}61 \\
56 \\
66 \\
63\end{array}$ & $\begin{array}{l}54 \\
64 \\
54 \\
53\end{array}$ & $\begin{array}{l}32 \\
25 \\
28 \\
28\end{array}$ & $\begin{array}{l}28 \\
12 \\
16 \\
15\end{array}$ & $\begin{array}{r}9 \\
10 \\
6 \\
8\end{array}$ & $\begin{array}{r}12 \\
8 \\
6 \\
5\end{array}$ & $\begin{array}{r}13 \\
5 \\
4 \\
6\end{array}$ & $\begin{array}{l}6 \\
4 \\
5 \\
9\end{array}$ & $\begin{array}{l}624 \\
707 \\
726 \\
353\end{array}$ \\
\hline $\begin{array}{l}\text { Size of community } \\
\text { Large metropolitan areas---- } \\
\text { Small metropolitan areas-.-- } \\
\text { Nonmetropolitan areas-..---- }\end{array}$ & $\begin{array}{l}68 \\
59 \\
56\end{array}$ & $\begin{array}{l}56 \\
60 \\
55\end{array}$ & $\begin{array}{l}32 \\
26 \\
25\end{array}$ & $\begin{array}{l}20 \\
20 \\
19\end{array}$ & $\begin{array}{r}9 \\
10 \\
6\end{array}$ & $\begin{array}{r}11 \\
7 \\
6\end{array}$ & $\begin{array}{r}11 \\
5 \\
3\end{array}$ & $\begin{array}{l}7 \\
4 \\
5\end{array}$ & $\begin{array}{l}923 \\
659 \\
828\end{array}$ \\
\hline $\begin{array}{l}\text { Family income } \\
\text { Upper-a } \\
\text { Middle- Lower- }\end{array}$ & $\begin{array}{l}68 \\
58 \\
60\end{array}$ & $\begin{array}{l}56 \\
62 \\
52\end{array}$ & $\begin{array}{l}31 \\
27 \\
24\end{array}$ & $\begin{array}{l}21 \\
19 \\
20\end{array}$ & $\begin{array}{r}11 \\
7 \\
5\end{array}$ & $\begin{array}{r}13 \\
7 \\
4\end{array}$ & $\begin{array}{r}10 \\
5 \\
5\end{array}$ & $\begin{array}{l}6 \\
3 \\
6\end{array}$ & $\begin{array}{l}697 \\
802 \\
628\end{array}$ \\
\hline $\begin{array}{l}\text { Employment of homemaker } \\
\text { Fuld time-- } \\
\text { Part time-- } \\
\text { Not employed.... }\end{array}$ & $\begin{array}{l}64 \\
58 \\
61\end{array}$ & $\begin{array}{l}52 \\
60 \\
58\end{array}$ & $\begin{array}{l}29 \\
30 \\
27\end{array}$ & $\begin{array}{l}21 \\
23 \\
19\end{array}$ & $\begin{array}{l}8 \\
7 \\
9\end{array}$ & $\begin{array}{l}8 \\
7 \\
8\end{array}$ & $\begin{array}{r}6 \\
12 \\
6\end{array}$ & $\begin{array}{l}5 \\
6 \\
5\end{array}$ & $\begin{array}{r}526 \\
233 \\
1,651\end{array}$ \\
\hline $\begin{array}{l}\text { Education of homemaker } \\
\text { No high school- } \\
\text { Some high school- } \\
\text { High school graduate........ } \\
\text { College- }\end{array}$ & $\begin{array}{l}58 \\
62 \\
62 \\
64\end{array}$ & $\begin{array}{l}56 \\
56 \\
59 \\
54\end{array}$ & $\begin{array}{l}26 \\
26 \\
30 \\
28\end{array}$ & $\begin{array}{l}19 \\
20 \\
19 \\
21\end{array}$ & $\begin{array}{r}6 \\
5 \\
8 \\
16\end{array}$ & $\begin{array}{r}5 \\
8 \\
9 \\
10\end{array}$ & $\begin{array}{l}6 \\
5 \\
7 \\
9\end{array}$ & $\begin{array}{l}4 \\
4 \\
5 \\
9\end{array}$ & $\begin{array}{l}580 \\
513 \\
852 \\
458\end{array}$ \\
\hline $\begin{array}{l}\text { Age of homemaker } \\
\text { Under } 36 \text { years } \\
36-50 \text { years } \\
\text { Over } 50 \text { years........................ }\end{array}$ & $\begin{array}{l}66 \\
62 \\
56\end{array}$ & $\begin{array}{l}59 \\
57 \\
55\end{array}$ & $\begin{array}{l}29 \\
31 \\
24\end{array}$ & $\begin{array}{l}16 \\
21 \\
22\end{array}$ & $\begin{array}{r}5 \\
9 \\
10\end{array}$ & $\begin{array}{l}9 \\
9 \\
5\end{array}$ & $\begin{array}{l}6 \\
7 \\
7\end{array}$ & $\begin{array}{l}4 \\
6 \\
5\end{array}$ & $\begin{array}{l}783 \\
825 \\
785\end{array}$ \\
\hline $\begin{array}{l}\text { Family composition } \\
\text { No children-- } \\
\text { Children under } 6 \text { only-.-. } \\
\text { Children } 6-17 \text { only-- } \\
\text { Children in both age groups- }\end{array}$ & $\begin{array}{l}57 \\
62 \\
63 \\
69\end{array}$ & $\begin{array}{l}52 \\
61 \\
59 \\
61\end{array}$ & $\begin{array}{l}25 \\
30 \\
28 \\
33\end{array}$ & $\begin{array}{l}22 \\
17 \\
20 \\
15\end{array}$ & $\begin{array}{r}10 \\
5 \\
8 \\
8\end{array}$ & $\begin{array}{r}6 \\
6 \\
10 \\
12\end{array}$ & $\begin{array}{l}7 \\
5 \\
8 \\
5\end{array}$ & $\begin{array}{l}6 \\
3 \\
6 \\
4\end{array}$ & $\begin{array}{l}985 \\
318 \\
689 \\
418\end{array}$ \\
\hline $\begin{array}{l}\text { Size of household } \\
\text { Small } \\
\text { Medium- } \\
\text { Large- }\end{array}$ & $\begin{array}{l}56 \\
62 \\
66\end{array}$ & $\begin{array}{l}51 \\
59 \\
61\end{array}$ & $\begin{array}{l}24 \\
29 \\
31\end{array}$ & $\begin{array}{l}21 \\
20 \\
18\end{array}$ & $\begin{array}{r}10 \\
8 \\
7\end{array}$ & $\begin{array}{r}6 \\
9 \\
10\end{array}$ & $\begin{array}{l}7 \\
7 \\
6\end{array}$ & $\begin{array}{l}5 \\
6 \\
5\end{array}$ & $\begin{array}{l}816 \\
892 \\
702\end{array}$ \\
\hline
\end{tabular}

I Percentages add to more than 100 because some homemakers bought more than one fruit last time.

2 None of these fruits was bought by more than 1 percent of the homemakers.

35 respondents could not recall what fruit they had purchased last time.

Table 16.--Homemakers who had purchased fresh fruit in the past 12 months: "What kind of fresh fruit did you buy last? Which one of these statements comes closest to describing how you decided to buy (FRUIT)?"

\begin{tabular}{|c|c|c|c|c|c|c|c|c|c|}
\hline \multirow[b]{2}{*}{$\begin{array}{l}\text { How decision was made to } \\
\text { buy specific fruit }\end{array}$} & \multirow{2}{*}{$\begin{array}{l}\text { All } \\
\text { fruits }\end{array}$} & \multicolumn{8}{|c|}{ Fresh fruits purchased last time } \\
\hline & & Apples & Oranges & Bananas & Grapefruit & Pears & Grapes & Tangerines & $\begin{array}{l}\text { All } \\
\text { other } \\
\text { fruits }\end{array}$ \\
\hline & Percent & Percent & $\underline{\text { Percent }}$ & Percent & Percent & Percent & Percent & Percent & Percent \\
\hline $\begin{array}{l}\text { Planned to buy this fruit } \\
\text { before entering the store-- }\end{array}$ & 62 & 68 & 67 & 63 & 61 & 51 & 46 & 40 & 52 \\
\hline $\begin{array}{l}\text { Planned to buy some kind of } \\
\text { fruit, but decided on this } \\
\text { kind in the store-.... }\end{array}$ & 24 & 18 & 22 & 23 & 27 & 41 & 37 & 46 & 27 \\
\hline $\begin{array}{l}\text { Didn't plan to buy fmuit } \\
\text { ahead of time; decided to } \\
\text { buy this kind in the store- }\end{array}$ & 12 & 12 & 9 & 13 & 9 & 7 & 14 & 11 & 19 \\
\hline Not ascertained-................ & 2 & 2 & 2 & 1 & 3 & 1 & 3 & 3 & 2 \\
\hline Number of cases-.....- & 4,685 & 1,479 & 675 & 1,368 & 199 & 165 & 474 & 297 & 128 \\
\hline
\end{tabular}


Table 17...-Homemakers who had purchased fresh fruit in the past 12 months: Sumary of when decision to purchase specific fruits bought last time was made

When decision was made

\begin{tabular}{|c|c|c|c|c}
$\begin{array}{c}\text { United } \\
\text { States } \\
\text { total }\end{array}$ & Northeast & $\begin{array}{c}\text { North } \\
\text { Central }\end{array}$ & South & West \\
\hline Percent & Percent & Percent & Percent & Percent \\
53 & 60 & 47 & 53 & 50 \\
16 & 16 & 20 & 14 & 15 \\
14 & 13 & 14 & 13 & 17 \\
15 & 9 & 18 & 17 & 16 \\
2 & 2 & 1 & 3 & 2 \\
\hline \hline 2,410 & 624 & 707 & 726 & 353 \\
\hline
\end{tabular}

Table 18.--Homemakers who had purchased fresh fruit in the past 12 months: "What kind of fresh fruit cid you buy last? Did you buy (FRUTT) loose or already in some kind of bag or container?"

Planned to buy all fruits purchased before entering

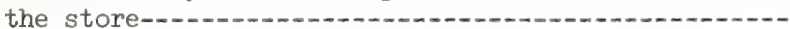

Planned to buy some of the fruits purchased, and

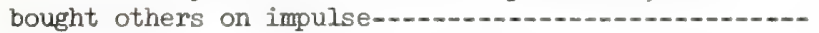

Planned to buy some kind of fruit, but decided on each kind in the store

Didn't plan to buy any fruit ahead of time............ Not ascertained

Number of cases

\begin{tabular}{|c|c|c|c|c|c|}
\hline Total fruits & $\begin{array}{l}\text { United } \\
\text { States } \\
\text { total }\end{array}$ & Loose & Packaged & No answer & Cases \\
\hline & Percent & Percent & Percent & Percent & Number \\
\hline Apples-n-n-nen & 61 & 59 & 40 & 1 & 1,479 \\
\hline Bananas-n-nen & 57 & 89 & 9 & 2 & 1,368 \\
\hline Oranges-n- & 28 & 64 & 35 & 1 & 675 \\
\hline Grapes-nen & 20 & 77 & 21 & 2 & 474 \\
\hline Grapefruit-n. & 8 & 59 & 37 & 4 & 199 \\
\hline Tangerines-n- & 8 & 78 & 21 & 1 & 197 \\
\hline Pears-n-men & 7 & 79 & 21 & (*) & 165 \\
\hline All other fruits & 5 & 72 & 20 & 8 & 128 \\
\hline
\end{tabular}

1 United States total adds to more than 100 because some homemakers bought more than one fruit the last time.

*Less than 1 percent.

Table 19.--Percentage distribution of how fruit was purchased by homemakers "last time"

How fruit was bought "last time"

\begin{tabular}{|c|c|c|c|c|}
\hline $\begin{array}{l}\text { United } \\
\text { States } \\
\text { total }\end{array}$ & Northeast & $\begin{array}{c}\text { North } \\
\text { Central }\end{array}$ & South & West \\
\hline Percent & Percent & Percent & Percent & Percent \\
\hline 61 & 53 & 51 & 66 & 82 \\
\hline 16 & 21 & 19 & 15 & 6 \\
\hline 21 & 25 & 27 & 17 & 10 \\
\hline 2 & 1 & 3 & 2 & 2 \\
\hline 2,410 & 624 & 707 & 726 & 353 \\
\hline
\end{tabular}


Table 20.--Homemakers who had purchased fresh fruit in the past 12 months: "In general, would you like to buy fresh fruit that is already in some kind of bag or container, or would you rather buy it loose?"

\begin{tabular}{|c|c|c|c|c|}
\hline Background characteristics & Loose & Packaged & $\begin{array}{c}\text { No } \\
\text { preference }\end{array}$ & Cases \\
\hline & Percent & Percent & Percent & Number \\
\hline 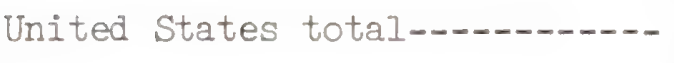 & 75 & 16 & 9 & 2,415 \\
\hline \\
\hline & 70 & 18 & 12 & 625 \\
\hline & $\begin{array}{l}72 \\
74\end{array}$ & 20 & 8 & 709 \\
\hline Wouth-1. & $\begin{array}{l}74 \\
89\end{array}$ & $\begin{array}{r}10 \\
4\end{array}$ & $\begin{array}{l}10 \\
7\end{array}$ & $\begin{array}{l}728 \\
353\end{array}$ \\
\hline \multicolumn{5}{|l|}{ Size of community: } \\
\hline Large metropolitan areas------ & 76 & 14 & 10 & 923 \\
\hline Small metropolitan areas-..-- & 77 & 14 & 9 & 663 \\
\hline Nonmetropolitan areas........- & 70 & 20 & 10 & 829 \\
\hline \multicolumn{5}{|l|}{ Family income: } \\
\hline 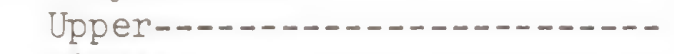 & 78 & 13 & 9 & 697 \\
\hline 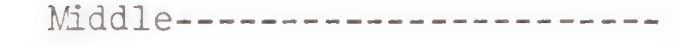 & 75 & 16 & 9 & 804 \\
\hline Lower-n-..-n & 70 & 20 & 10 & 630 \\
\hline \multicolumn{5}{|l|}{ Employment of homemaker: } \\
\hline 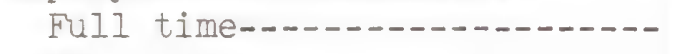 & 75 & 15 & 10 & 529 \\
\hline Part time-n. & 72 & 18 & 10 & 233 \\
\hline 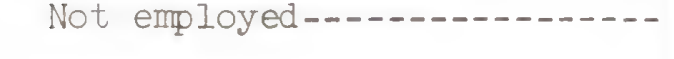 & 75 & 16 & 9 & 1,653 \\
\hline \multicolumn{5}{|l|}{ Education of homemaker: } \\
\hline 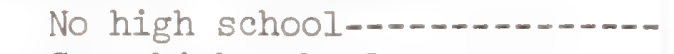 & 70 & 18 & 12 & 582 \\
\hline Some high school-................. & 75 & 15 & 10 & 514 \\
\hline High school graduate-.........- & 74 & 17 & 9 & 853 \\
\hline College-n-n & 79 & 14 & 7 & 459 \\
\hline \multicolumn{5}{|l|}{ Age of homemaker: } \\
\hline Under 16 years & 73 & 29 & 8 & 785 \\
\hline 36-50 years-n-...- & 75 & 15 & 10 & 825 \\
\hline Over 50 years-n- & 76 & 14 & 10 & 788 \\
\hline \multicolumn{5}{|l|}{ Family composition: } \\
\hline No children-- & 77 & 13 & 10 & 990 \\
\hline Children under 6 only--.-.-.- & 70 & 22 & 8 & 318 \\
\hline Children 6-17 only--.-.-...- & 76 & 15 & 9 & 689 \\
\hline Children in both age groups-- & 70 & 20 & 10 & 418 \\
\hline \multicolumn{5}{|l|}{ Size of household: } \\
\hline 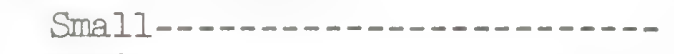 & 79 & 12 & 9 & 819 \\
\hline Medium-- & 75 & 15 & 10 & 894 \\
\hline 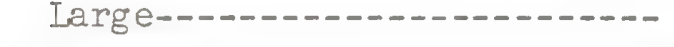 & 69 & 21 & 10 & 702 \\
\hline
\end{tabular}


Table 21.--Homemakers who had purchased fresh fruit in the past 12 months and preferred to buy it loose: "Are there any fresh fruits you don't like to buy this way? Which ones?"1

\begin{tabular}{|c|c|}
\hline Preferences & $\begin{array}{c}\text { Homemakers who prefer } \\
\text { to buy fresh fruft } \\
\text { loose }\end{array}$ \\
\hline & Percent \\
\hline PREFER TO BUY AIL KINDS LOASE & 89 \\
\hline PREFER TO BUY SOME KINDS PACKAGED & 10 \\
\hline Apples $-\ldots \ldots-n$ & 2 \\
\hline 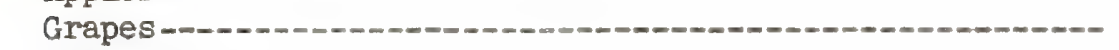 & 2 \\
\hline Oranges $-\cdots-m-1$ & 2 \\
\hline Strawberries $-1,-10$ & 2 \\
\hline 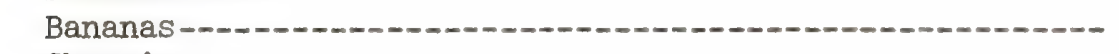 & 1 \\
\hline Cherries-1- & 1 \\
\hline Grapef ruit & 1 \\
\hline All other fresh fruits & 2 \\
\hline NOT ASCERTAINED -............ & 1 \\
\hline Number of cases & 1,800 \\
\hline
\end{tabular}

${ }^{1}$ Percentages add to more than the group total because some respondents named more than 1 fruit.

Tahle 22.--Homemakers who had purchased fresh fruit in the past 12 months and preferred to buy fresh fruit packaged: "Are there any fresh fruits you don't like to buy this way? Which ones?"I

Preferences
Homemakers who prefer to buy fresh fruit packaged

\begin{tabular}{|c|c|}
\hline & Percent \\
\hline PREFER TO BUY ALL KINDS PACKAGED-.. & 58 \\
\hline PREFER TO BUY SOME KINDS LOQSE & 40 \\
\hline Bananas - & 15 \\
\hline 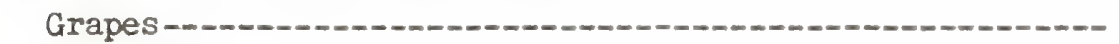 & 12 \\
\hline 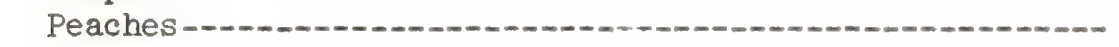 & 8 \\
\hline 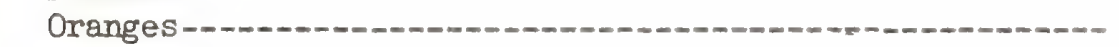 & 5 \\
\hline Pears-1-n & 3 \\
\hline Apples & 2 \\
\hline Grapef ruit $-\cdots$ & 2 \\
\hline Plums, fresh prunes- & 2 \\
\hline Cherries-1- & 1 \\
\hline Strawberries & 1 \\
\hline Ail other fresh fruits & 4 \\
\hline NOT ASCERTAINED & 2 \\
\hline Number of cases & 385 \\
\hline
\end{tabular}

1 Percentages add to more than their group total because some respondents named more than 1 fruit. 
Table 23.--Homemakers who had purchased fresh fruit in the past 12 months: "What are the advantages of buying fresh fruit loose?"1

\begin{tabular}{|c|c|c|c|c|}
\hline $\begin{array}{l}\text { Advantages of buying fresh } \\
\text { fruit loose }\end{array}$ & $\begin{array}{l}\text { United } \\
\text { States } \\
\text { total }\end{array}$ & $\begin{array}{l}\text { Homemakers } \\
\text { who prefer } \\
\text { to buy } \\
\text { loose iruit }\end{array}$ & $\begin{array}{l}\text { Homemakers } \\
\text { who prefer } \\
\text { to buy } \\
\text { packaged fruit }\end{array}$ & $\begin{array}{l}\text { Homemakers } \\
\text { who have no } \\
\text { preference }\end{array}$ \\
\hline & Percent & Percent & Percent & Percent \\
\hline 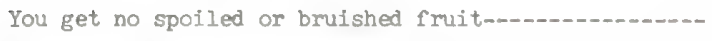 & 54 & 59 & 37 & 39 \\
\hline You can get the number you want & 31 & 33 & 28 & 23 \\
\hline You can choose the ones you want & 29 & 30 & 25 & 35 \\
\hline You can get the size you want_. & 13 & 14 & 7 & 10 \\
\hline 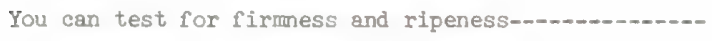 & 8 & 8 & 6 & 5 \\
\hline It is fresher & 8 & 10 & 2 & 3 \\
\hline It is less expensive & 7 & 6 & 11 & 9 \\
\hline You can get the degree of ripeness you want-............. & 6 & 6 & 5 & 4 \\
\hline It is more attractiven- & 1 & 2 & 1 & 1 \\
\hline You can see the color-.-- & 1 & 1 & $(*)$ & 1 \\
\hline All other answers & 1 & 1 & 1 & 1 \\
\hline There are no advantages--. & 4 & -- & 16 & 7 \\
\hline Not ascertained--......- & 1 & $(*)$ & 2 & 5 \\
\hline Number of cases---- & 2,415 & 1,800 & 385 & 230 \\
\hline
\end{tabular}

1 Percentages add to more than 100 because some respondents gave more than 1 advantage.

* Less than 1 percent.

Table 24.--Homemakers who had purchased fresh frult in the past 12 months: "What are the advantages of buying fresh fruit in some kind of bag or container?"1

\begin{tabular}{|c|c|c|c|c|}
\hline $\begin{array}{c}\text { Advantages of buying fresh } \\
\text { fruit packaged }\end{array}$ & $\begin{array}{l}\text { United } \\
\text { States } \\
\text { total }\end{array}$ & $\begin{array}{c}\text { Homemakers } \\
\text { who prefer } \\
\text { to buy } \\
\text { packaged fruit }\end{array}$ & $\begin{array}{l}\text { Homemakers } \\
\text { who prefer } \\
\text { to buy } \\
\text { loose fruit }\end{array}$ & $\begin{array}{l}\text { Homemakers } \\
\text { who have no } \\
\text { pref erence }\end{array}$ \\
\hline & Percent & Percent & Percent & Percent \\
\hline It's time saving & 28 & 42 & 24 & 41 \\
\hline It is not handled.................. & 14 & 32 & 9 & 17 \\
\hline 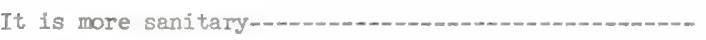 & 10 & 25 & 7 & 9 \\
\hline It is easy to pick up- & 9 & 14 & 8 & 16 \\
\hline It is less expensive-1. & 9 & 11 & 9 & 13 \\
\hline It is easy to carry & 6 & 8 & 6 & 6 \\
\hline It is easy to store & 5 & 9 & 4 & 6 \\
\hline It is protected-n. & 4 & 9 & 3 & 6 \\
\hline It is more convenient (general) & 4 & 5 & 4 & 5 \\
\hline It is already priced & 3 & 8 & 2 & 3 \\
\hline It has a clear transparent bag-.......................... & 3 & 7 & 1 & 5 \\
\hline 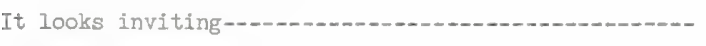 & 2 & 6 & 1 & 2 \\
\hline It keeps fresher-n. & 2 & 6 & 1 & 1 \\
\hline Better choice and quality-...- & 1 & 3 & 1 & 1 \\
\hline 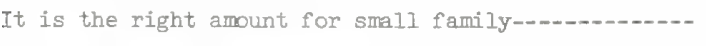 & 1 & 2 & 1 & 2 \\
\hline It has a reusahle container & 1 & 1 & (*) & -- \\
\hline All other answers & $I$ & 1 & (*) & (*) \\
\hline There are no advantages-_- & 36 & 4 & 46 & 18 \\
\hline 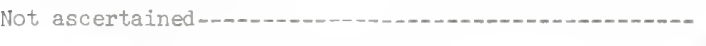 & 1 & 1 & 1 & 4 \\
\hline Number of cases-.-.-....... & 2,415 & 385 & 1,800 & 230 \\
\hline
\end{tabular}

\footnotetext{
I Percentages may add to more than 100 because some respondents gave more than 1 advantage.

* Less than 1 percent.
} 


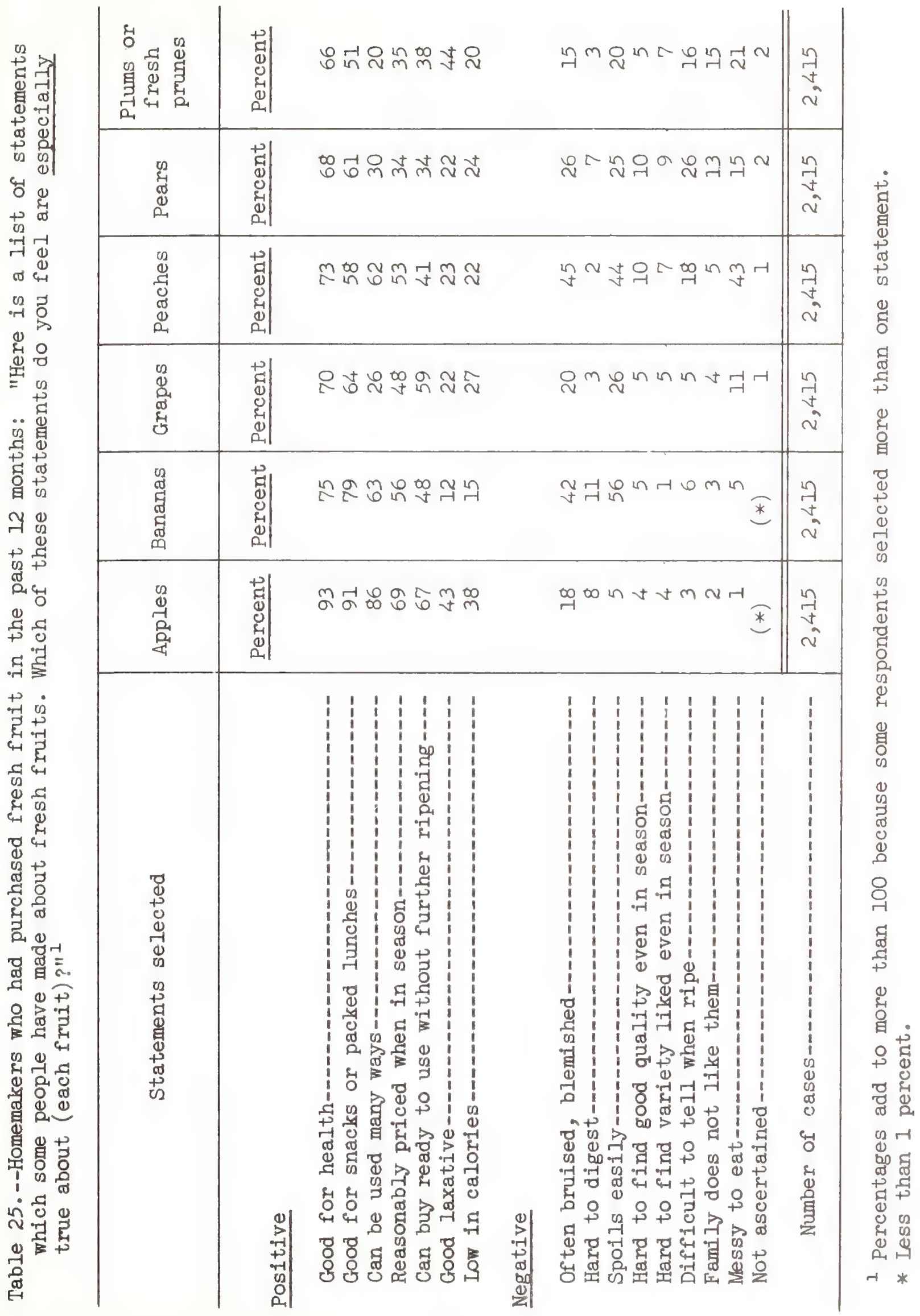




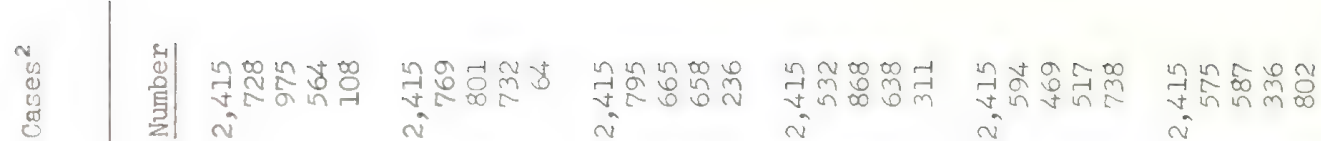

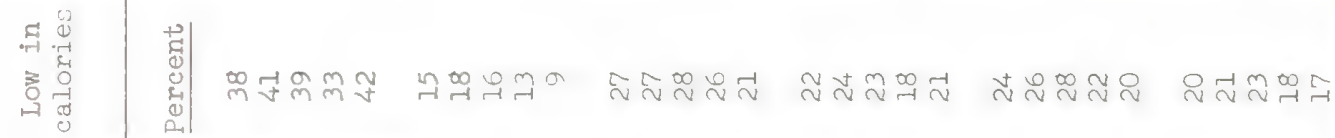

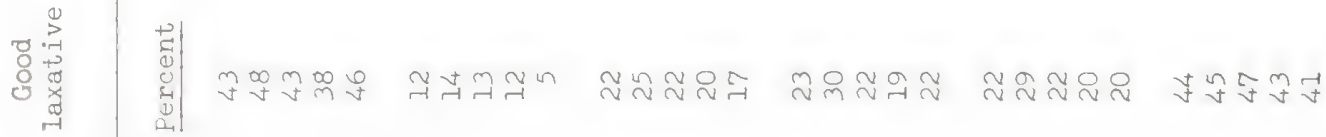

$\rightarrow$

ํํㅇํำ

肯尔

กำิำ

ํํำำ

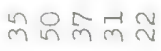

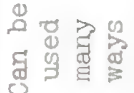

\section{|}

$\infty$ 这苾

ติธูก

ำกำำง

ขึกตูก

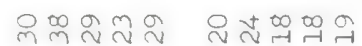

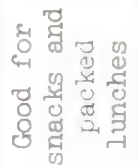

\section{0
0
0
0
0
0.1}

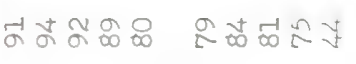

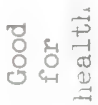

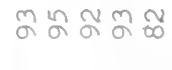

유무

전요

$m^{\infty} \pi N-1$

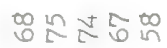

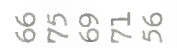

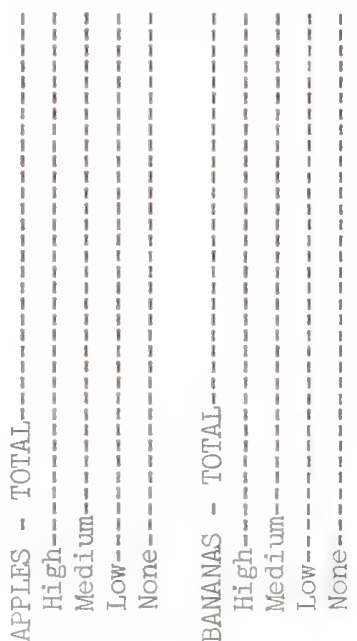

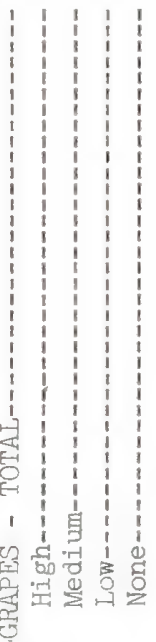

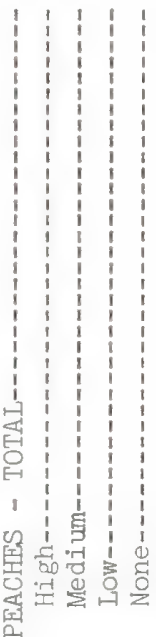

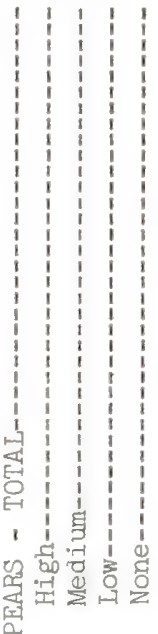

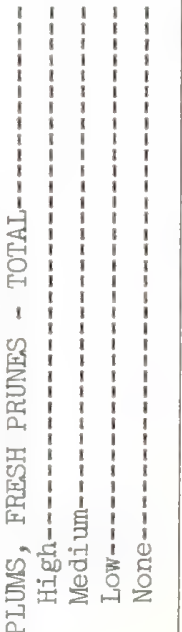

苦 


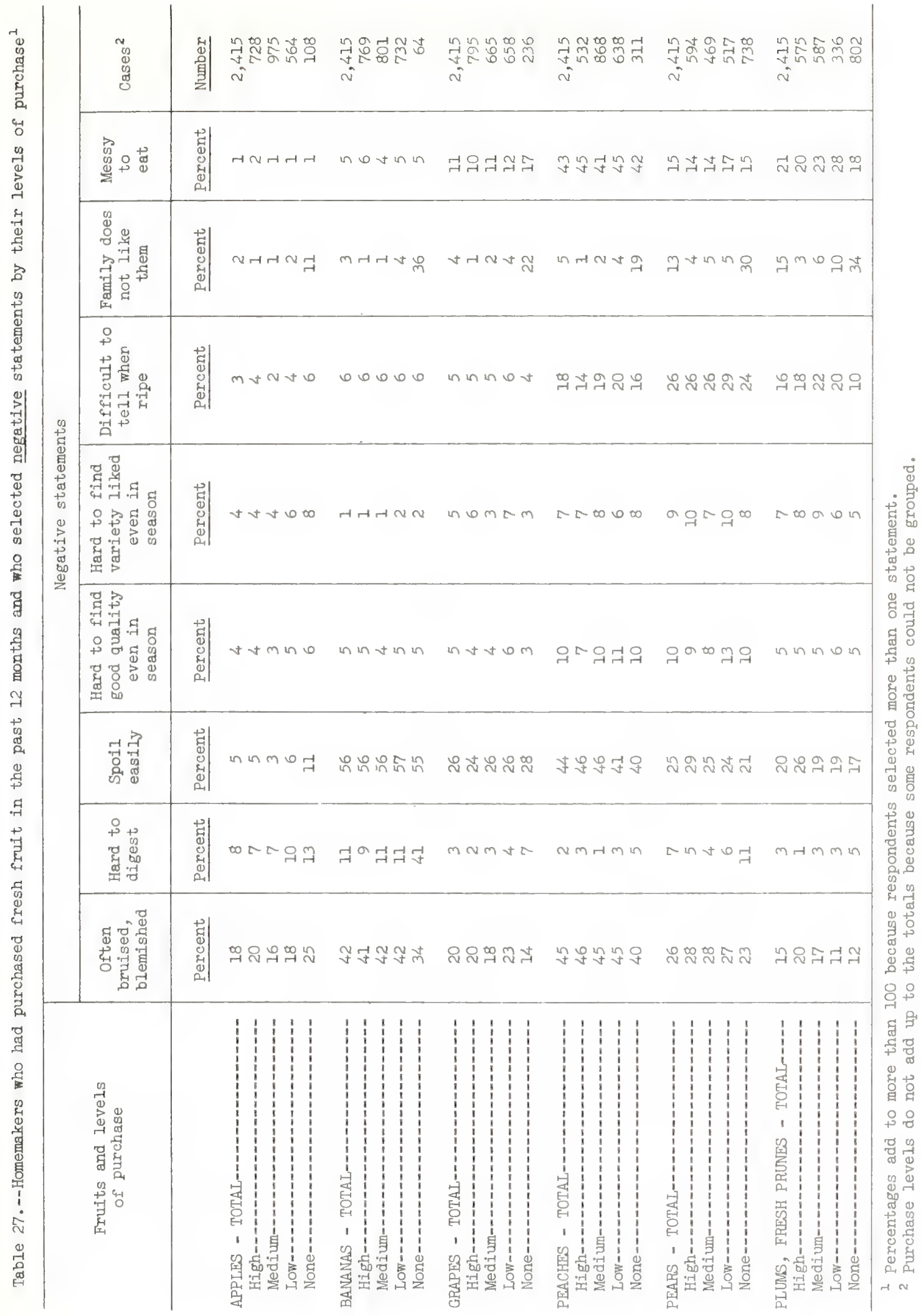




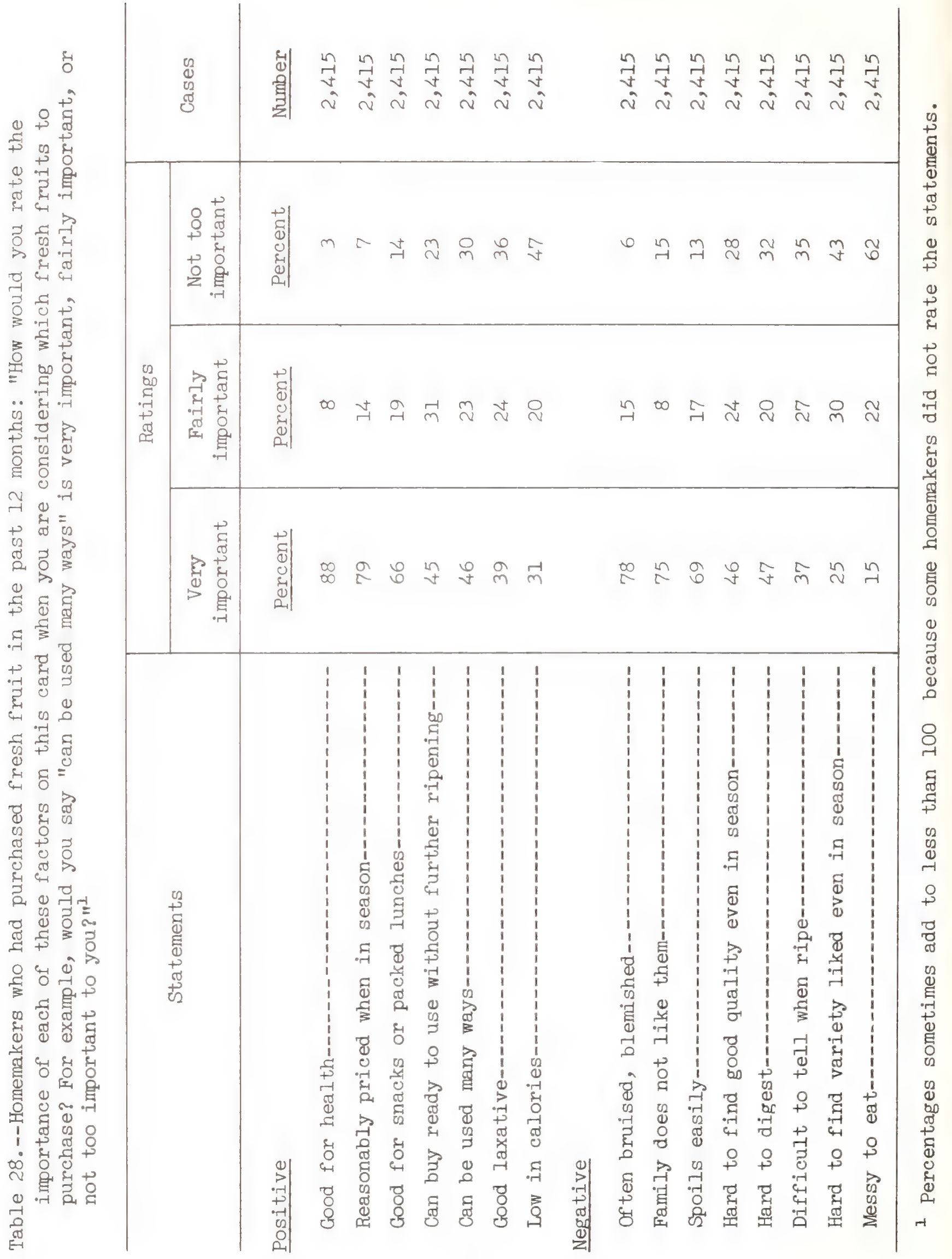




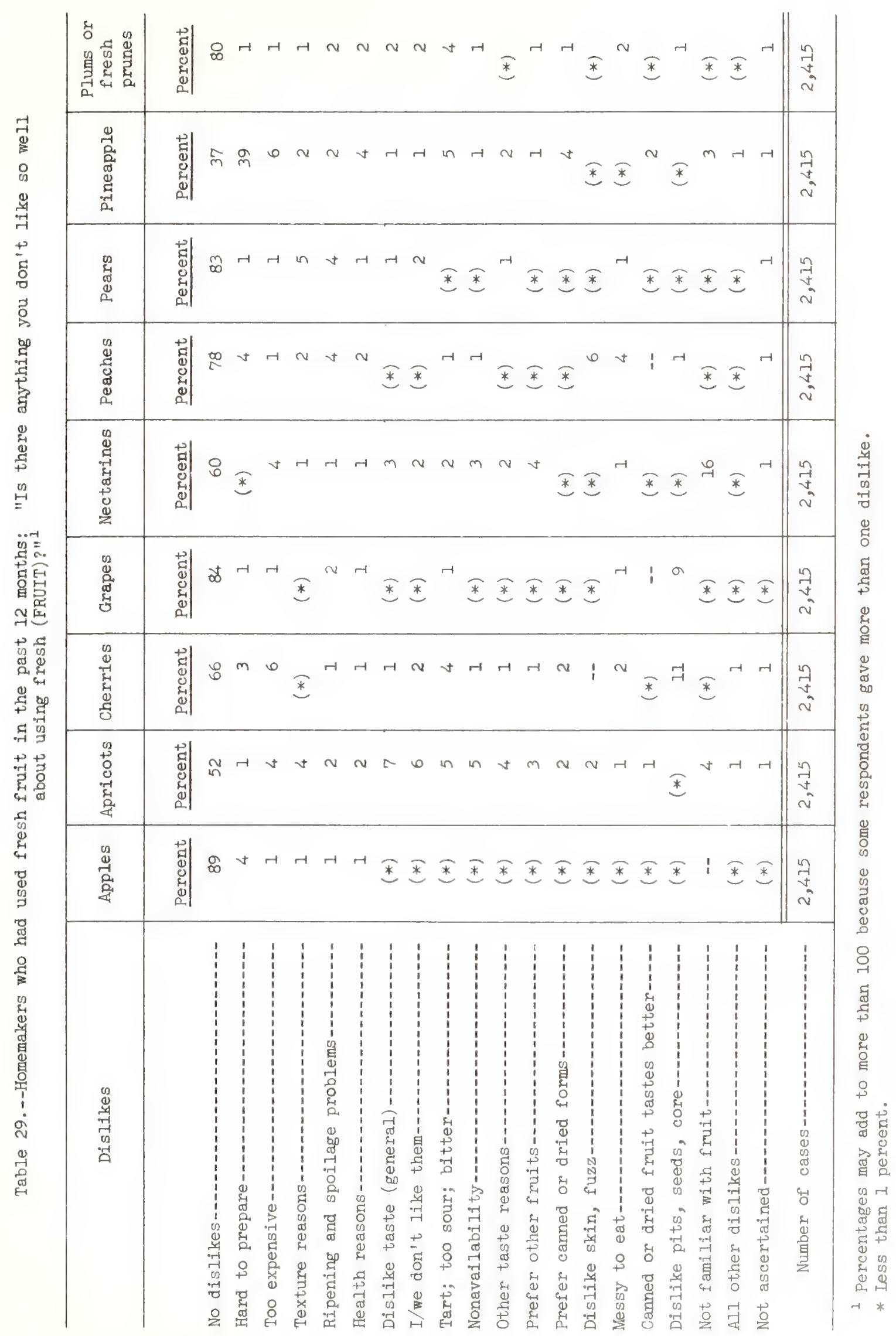




\begin{tabular}{|c|c|c|c|c|c|c|c|c|c|}
\hline $\begin{array}{l}02 \\
0 \\
07 \\
0 \\
0\end{array}$ & $\begin{array}{l}0 \\
0 \\
0 \\
\vdots \\
\vdots \\
\vdots\end{array}$ & $\begin{array}{l}\text { ?7 } \\
\text { va } \\
\text { va }\end{array}$ & 고욨 & స్. & స઼ेర్లో & 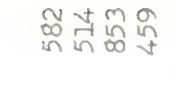 & $\stackrel{n}{\infty} \underset{\infty}{\infty} \underset{\infty}{\infty}$ & 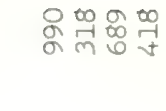 & స్ \\
\hline 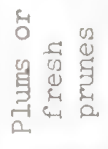 & \begin{tabular}{l|}
0 \\
0 \\
0 \\
0 \\
0 \\
0 \\
0
\end{tabular} & $\infty$ & ๘ & ma & 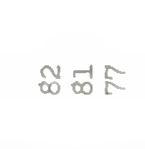 & $\left.\mathfrak{\infty}^{+\infty}+\infty\right)^{\infty}$ & $\infty \infty_{\infty}^{-1}$ & $a^{\infty} \approx 0$ & $2+\infty-1$ \\
\hline 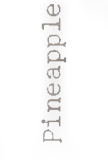 & 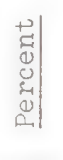 & m & 声品命出 & 봉 & సे లొ & ษ઼๊ల్లి & $\stackrel{m}{\text { mे }} \tilde{v}$ & ㅇำ & i ले \\
\hline 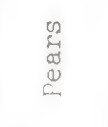 & $\begin{array}{l}3 \\
\vdots \\
0 \\
0 \\
0 \\
0 \\
2\end{array}$ & $m$ & 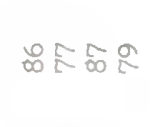 & $\stackrel{\infty}{\infty} \stackrel{\infty}{\infty}$ & $\begin{array}{ll}-1 \\
\infty\end{array}$ & ఐ & $-1-1 \infty$ & జ & జీ \\
\hline 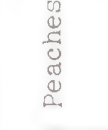 & $\begin{array}{l}+ \\
0 \\
0 \\
0 \\
0 \\
0 \\
0.1\end{array}$ & to & 이요요 & $\stackrel{\infty}{2} \approx m$ & $\mathbb{L}^{+\infty} \underset{\infty}{m}$ & $\infty$ & $\cong 2$ & 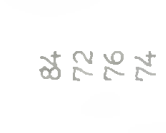 & $\infty$ \\
\hline 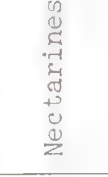 & $\begin{array}{l}2 \\
0 \\
0 \\
0 \\
0 \\
0\end{array}$ & 8 & 부요 & 菏会会 & b i & 经范 & 会 증 & in in & 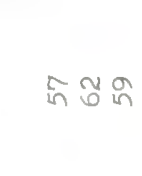 \\
\hline $\begin{array}{l}0 \\
0 \\
0 \\
0 \\
0 \\
0 \\
0\end{array}$ & \begin{tabular}{l}
+ \\
\multicolumn{2}{|}{} \\
0 \\
0 \\
$\vdots$ \\
0 \\
2
\end{tabular} & జ & 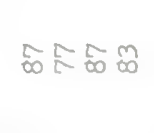 & జ & 品 & దิ & mo & బీ & 公 \\
\hline 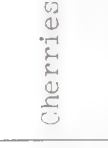 & $\begin{array}{l}0 \\
0 \\
0 \\
0 \\
0 \\
0 \\
2\end{array}$ & 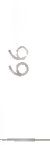 & toㅇㅇㅇㅇㅛ & 도 & 趈 & 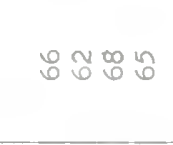 & ีํㅇํำ & 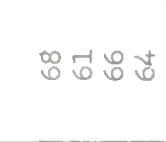 & $\infty$ : 2 ह \\
\hline 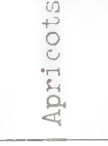 & $\begin{array}{l}\overrightarrow{2} \\
0 \\
0 \\
0 \\
0 \\
0\end{array}$ & $\tilde{n}$ & 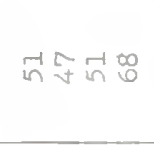 & 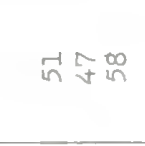 & 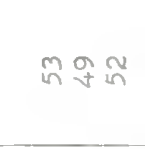 & 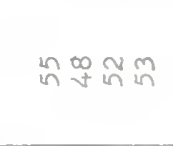 & $\stackrel{0}{+} \operatorname{tn}^{-1}$ 응 & 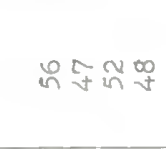 & 㻤过早 \\
\hline 哇 & $\begin{array}{l}0 \\
0 \\
0 \\
0 \\
0 \\
0 \\
2\end{array}$ & $\infty$ & 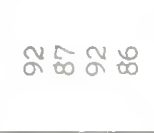 & $\begin{array}{l}\infty \\
\infty \\
\infty\end{array}$ & 웅요 & హન & 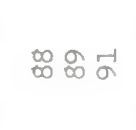 & స్రం & 요 ๘- \\
\hline 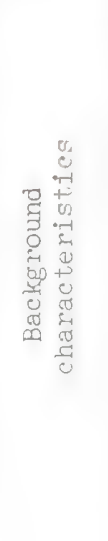 & & 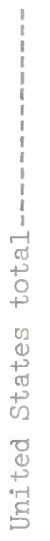 & 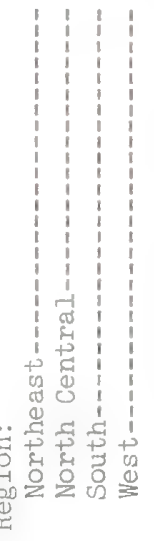 & 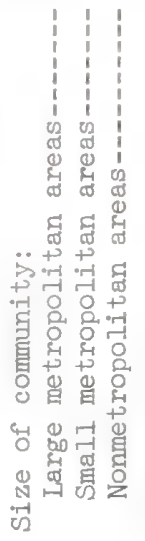 & 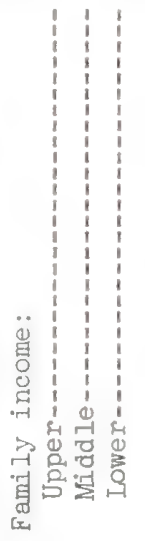 & 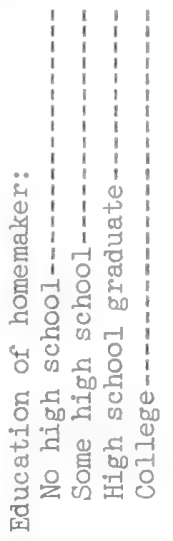 & 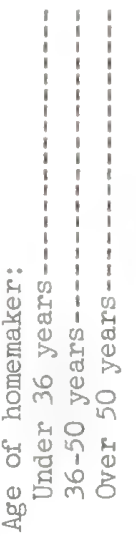 & 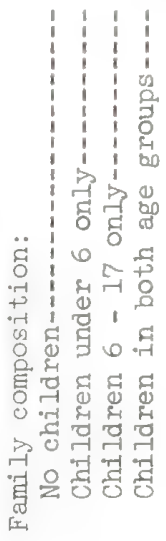 & 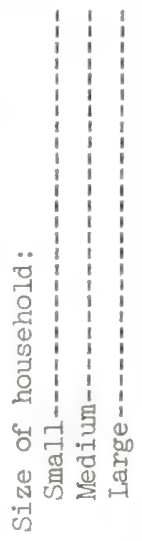 \\
\hline
\end{tabular}




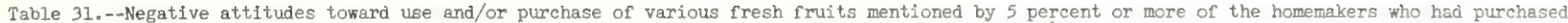
fresh fruit in the past 12 months (Q. 1 and 23)

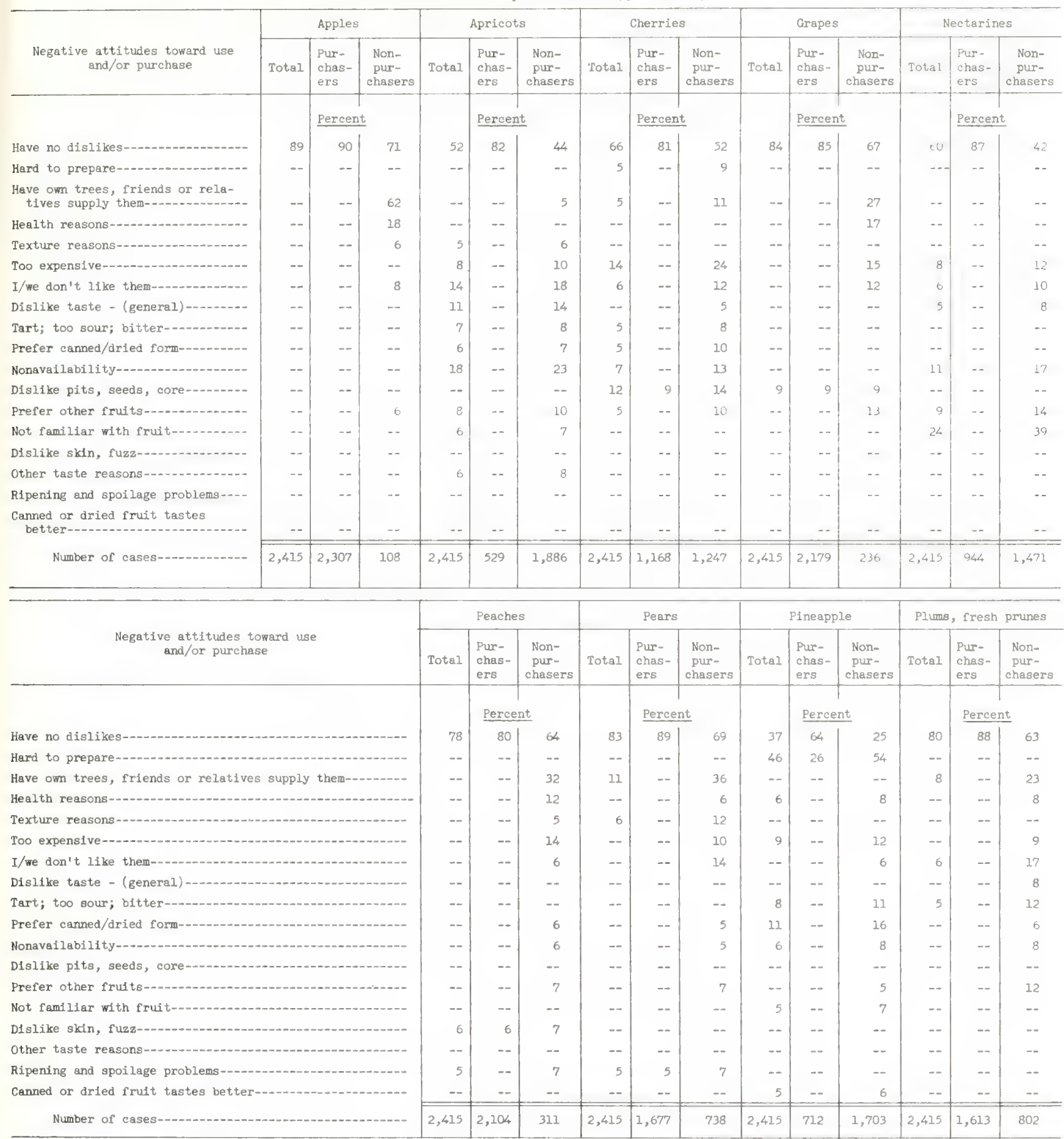

1 This table represents a summary of reasons for nonuse of the various fruits and homemakers' dislikes of the specific fruits. 


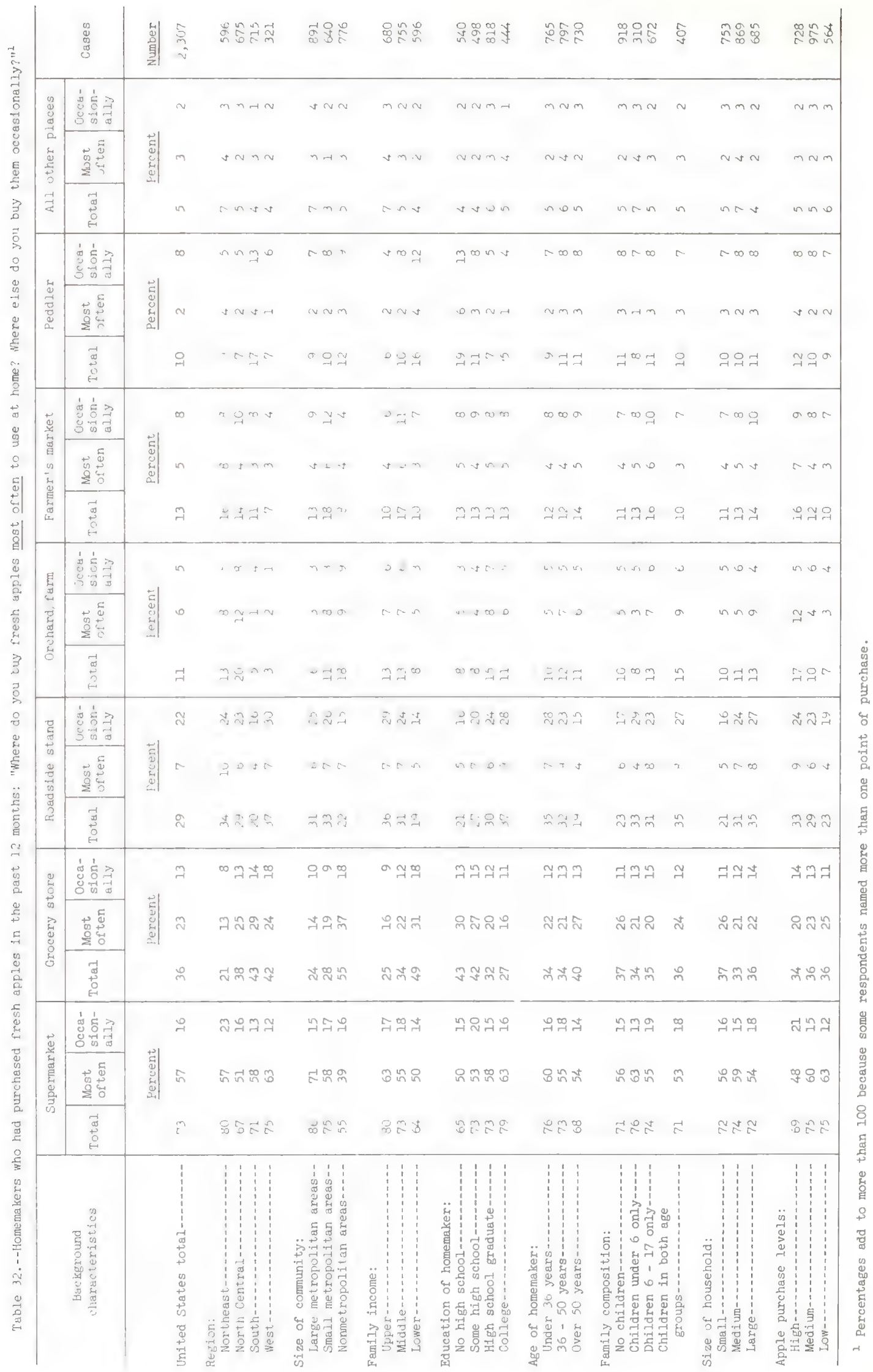


Table 33.--Homemakers who had purchased fresh apples in the past 12 months: "During the fall and winter do you use fresh apples at least once a week or do you use them less often? What about the spring? What about the summer?"

\begin{tabular}{|c|c|c|c|c|c|c|c|}
\hline \multirow[b]{2}{*}{ Background characteristics } & \multicolumn{2}{|c|}{ Fall and winter } & \multicolumn{2}{|c|}{ Spring } & \multicolumn{2}{|c|}{ Summer } & \multirow[b]{2}{*}{ Cases } \\
\hline & $\begin{array}{l}\text { At least } \\
\text { once a } \\
\text { week }\end{array}$ & $\begin{array}{c}\text { Less than } \\
\text { once a } \\
\text { week }\end{array}$ & $\begin{array}{l}\text { At least } \\
\text { once a } \\
\text { week }\end{array}$ & $\begin{array}{c}\text { Less than } \\
\text { once a } \\
\text { week }\end{array}$ & $\begin{array}{c}\text { At least } \\
\text { once a } \\
\text { meek }\end{array}$ & $\begin{array}{c}\text { Less than } \\
\text { once a } \\
\text { week }\end{array}$ & \\
\hline & Percent & Percent & Percent & Percent & Percent & Percent & Number \\
\hline United States total-nen- & 86 & 14 & 65 & 35 & 62 & 38 & 2,307 \\
\hline $\begin{array}{l}\text { Region: } \\
\text { Northeast- } \\
\text { North Central } \\
\text { South } \\
\text { West- }\end{array}$ & $\begin{array}{l}90 \\
83 \\
85 \\
85\end{array}$ & $\begin{array}{l}10 \\
17 \\
15 \\
1:\end{array}$ & $\begin{array}{l}71 \\
59 \\
68 \\
63\end{array}$ & $\begin{array}{l}29 \\
41 \\
32 \\
37\end{array}$ & $\begin{array}{l}64 \\
58 \\
65 \\
59\end{array}$ & $\begin{array}{l}36 \\
42 \\
35 \\
41\end{array}$ & $\begin{array}{l}596 \\
675 \\
715 \\
321\end{array}$ \\
\hline $\begin{array}{l}\text { Size of community: } \\
\text { Large metropolitan areas } \\
\text { Small metropolitan areas } \\
\text { Nonmetropolitan areas }\end{array}$ & $\begin{array}{l}87 \\
85 \\
85\end{array}$ & $\begin{array}{l}13 \\
15 \\
15\end{array}$ & $\begin{array}{l}72 \\
61 \\
61\end{array}$ & $\begin{array}{l}28 \\
39 \\
39\end{array}$ & $\begin{array}{l}68 \\
58 \\
58\end{array}$ & $\begin{array}{l}32 \\
42 \\
42\end{array}$ & $\begin{array}{l}891 \\
640 \\
776\end{array}$ \\
\hline $\begin{array}{l}\text { Family income: } \\
\text { Upperide } \\
\text { Middlew } \\
\text { Lower }\end{array}$ & $\begin{array}{l}90 \\
85 \\
83\end{array}$ & $\begin{array}{l}10 \\
15 \\
17\end{array}$ & $\begin{array}{l}70 \\
63 \\
65\end{array}$ & $\begin{array}{l}3 u \\
37 \\
35\end{array}$ & $\begin{array}{l}59 \\
64 \\
64\end{array}$ & $\begin{array}{l}41 \\
36 \\
36\end{array}$ & $\begin{array}{l}680 \\
755 \\
576\end{array}$ \\
\hline $\begin{array}{l}\text { Education of homemaker: } \\
\text { No high school } \\
\text { Some high school- } \\
\text { High school graduate- } \\
\text { College- }\end{array}$ & $\begin{array}{l}84 \\
84 \\
88 \\
85\end{array}$ & $\begin{array}{l}16 \\
16 \\
12 \\
15\end{array}$ & $\begin{array}{l}67 \\
63 \\
68 \\
61\end{array}$ & $\begin{array}{l}33 \\
37 \\
32 \\
39\end{array}$ & $\begin{array}{l}66 \\
63 \\
03 \\
53\end{array}$ & $\begin{array}{l}34 \\
37 \\
37 \\
47\end{array}$ & $\begin{array}{l}540 \\
438 \\
818 \\
444\end{array}$ \\
\hline $\begin{array}{l}\text { Age of homemaker: } \\
\text { Under } 36 \text { years } \\
36 \text { - } 50 \text { years } \\
\text { Over } 50 \text { years }\end{array}$ & $\begin{array}{l}83 \\
89 \\
85\end{array}$ & $\begin{array}{l}17 \\
11 \\
15\end{array}$ & $\begin{array}{l}64 \\
69 \\
62\end{array}$ & $\begin{array}{l}36 \\
31 \\
38\end{array}$ & $\begin{array}{l}03 \\
63 \\
59\end{array}$ & $\begin{array}{l}37 \\
37 \\
41\end{array}$ & $\begin{array}{l}765 \\
797 \\
730\end{array}$ \\
\hline $\begin{array}{l}\text { Family composition: } \\
\text { No children- } \\
\text { Children under } 6 \text { only- } \\
\text { Children } 6-17 \text { only } \\
\text { Children in both age groups }\end{array}$ & $\begin{array}{l}83 \\
79 \\
89 \\
93\end{array}$ & $\begin{array}{r}17 \\
21 \\
11 \\
7\end{array}$ & $\begin{array}{l}61 \\
64 \\
68 \\
71\end{array}$ & $\begin{array}{l}39 \\
36 \\
32 \\
29\end{array}$ & $\begin{array}{l}59 \\
64 \\
63 \\
66\end{array}$ & $\begin{array}{l}41 \\
36 \\
37 \\
34\end{array}$ & $\begin{array}{l}918 \\
310 \\
672 \\
407\end{array}$ \\
\hline $\begin{array}{l}\text { Size of household: } \\
\text { Small } \\
\text { Medium- } \\
\text { Large- }\end{array}$ & $\begin{array}{l}82 \\
86 \\
90\end{array}$ & $\begin{array}{l}18 \\
14 \\
10\end{array}$ & $\begin{array}{l}60 \\
66 \\
69\end{array}$ & $\begin{array}{l}40 \\
34 \\
31\end{array}$ & $\begin{array}{l}58 \\
63 \\
04\end{array}$ & $\begin{array}{l}42 \\
37 \\
36\end{array}$ & $\begin{array}{l}753 \\
869 \\
685\end{array}$ \\
\hline $\begin{array}{l}\text { Apple purchase levels: } \\
\text { High } \\
\text { Medium }\end{array}$ & $\begin{array}{l}95 \\
91 \\
66\end{array}$ & $\begin{array}{r}5 \\
9 \\
34\end{array}$ & $\begin{array}{l}75 \\
69 \\
46\end{array}$ & $\begin{array}{l}25 \\
31 \\
54\end{array}$ & $\begin{array}{l}69 \\
64 \\
48\end{array}$ & $\begin{array}{l}31 \\
36 \\
52\end{array}$ & $\begin{array}{l}728 \\
975 \\
564\end{array}$ \\
\hline
\end{tabular}

Table 34.--Homemakers who had purchased fresh apples in the past 12 months and had used them less often than once a week during certain seasons: "Why don't you use them more often during (SEASON)?"I

\begin{tabular}{|c|c|c|c|}
\hline Reasons for infrequent use & Fall and winter & Spring & Summer \\
\hline & Percent & Percent & Percent \\
\hline Too expensive-1- & 16 & 20 & 16 \\
\hline Like a variety of fruits & 14 & 10 & 5 \\
\hline Fewer people at home & 13 & 6 & 5 \\
\hline Have a taste for them only at certain times & 10 & 4 & 3 \\
\hline They have limited use-- & 8 & 4 & 4 \\
\hline 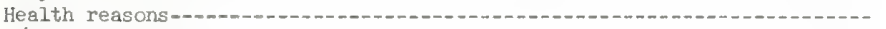 & 7 & 3 & 2 \\
\hline I/we don't like them- & 6 & 3 & 2 \\
\hline Not as good at this time of year & 5 & 25 & 20 \\
\hline Use, prefer other processed fruit-- & 5 & 2 & 1 \\
\hline 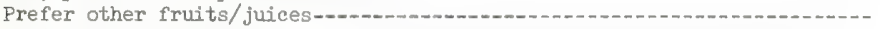 & 3 & 1 & 2 \\
\hline Don't shop that often in that season & 3 & 1 & 1 \\
\hline So many other fruits available & 2 & 18 & 35 \\
\hline Less variety avaílable--n- & 2 & 13 & 14 \\
\hline Prefer other foods & 2 & 2 & 2 \\
\hline Dislike taste-n-m & 1 & 4 & 3 \\
\hline Poor taste (general) & 1 & 4 & 3 \\
\hline Don't bake/pack lunches as much-1 & 1 & (*) & 1 \\
\hline Not in season (general) & -- & 3 & 2 \\
\hline All other reasons & 2 & 1 & 1 \\
\hline Not ascertained-1 & 7 & 3 & 3 \\
\hline Number of cases-c-nes & 327 & 799 & 881 \\
\hline
\end{tabular}

1 Percentages add to more than 100 because some respondents gave more than one reason.

* Less than 1 percent. 


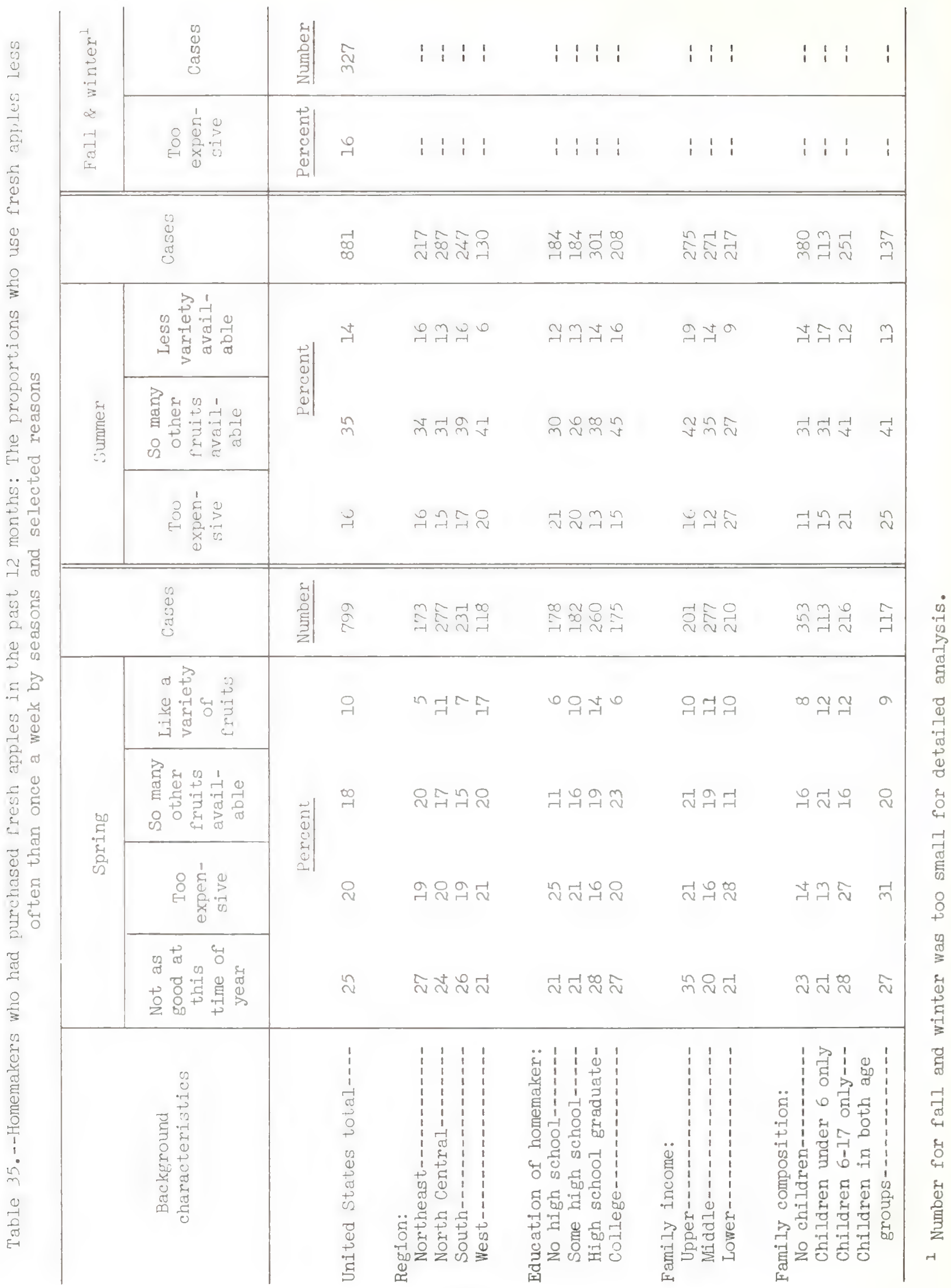


Table 36.--Homemakers who purchased fresh apples in the past 12 months: "During the past year, in which of these ways have you used raw apples in your home? Eaten out-of-hand? Salads? Fruit cups?"I

\begin{tabular}{l|c|c|c|c|c}
\hline $\begin{array}{c}\text { Background } \\
\text { characteristics }\end{array}$ & $\begin{array}{c}\text { For } \\
\text { eating out } \\
\text { of hand }\end{array}$ & $\begin{array}{c}\text { In } \\
\text { salads }\end{array}$ & fruit cups & $\begin{array}{c}\text { In other } \\
\text { ways }\end{array}$ & $\begin{array}{c}\text { Have not } \\
\text { used raw } \\
\text { apples }\end{array}$ \\
\hline United States total-_ases \\
Region:
\end{tabular}

1 Percentages add to more than 100 because some respondents mentioned more than one way of using raw apples.

2 Includes use in jello, use in taffy or candy apples, and other purposes.

*Less than 1 percent.

Table 37.--Homemakers who had used fresh apples raw in the past 12 months: "When are apples eaten raw by your family?" 1

\begin{tabular}{|c|c|c|c|c|c|c|}
\hline Background characteristics & $\begin{array}{l}\text { Daytime } \\
\text { snacks }\end{array}$ & $\begin{array}{r}\text { Evening } \\
\text { snacks }\end{array}$ & $\begin{array}{l}\text { Packed } \\
\text { lunches }\end{array}$ & $\begin{array}{c}\text { Meals at } \\
\text { home }\end{array}$ & $\begin{array}{l}\text { No } \\
\text { particular } \\
\text { time }\end{array}$ & Cases \\
\hline & Percent & Percent & Percent & Percent & Percent & Number \\
\hline United States total & 77 & 77 & 39 & 24 & 2 & 2,289 \\
\hline \multirow{2}{*}{\multicolumn{7}{|c|}{$\begin{array}{l}\text { Region: } \\
\text { Northeast }\end{array}$}} \\
\hline & 80 & 80 & 39 & 15 & 1 & 590 \\
\hline North Central-n. & 71 & 80 & 43 & 21 & 1 & 669 \\
\hline 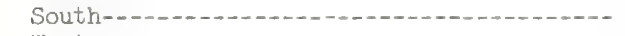 & 81 & 75 & 32 & 32 & $-\infty$ & 714 \\
\hline & 72 & 70 & 49 & 29 & 8 & 316 \\
\hline \multicolumn{7}{|l|}{ Size of community: } \\
\hline 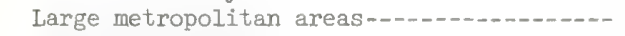 & 75 & 76 & 42 & 20 & 3 & 880 \\
\hline Small metropolitan areas-_.................... & 77 & 81 & 45 & 27 & 2 & 639 \\
\hline 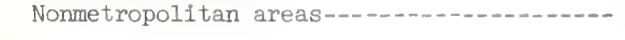 & 78 & 75 & 31 & 26 & $(*)$ & 770 \\
\hline \multicolumn{7}{|l|}{ Family income: } \\
\hline Upper-n-n-mon & 78 & 78 & 44 & 23 & 2 & 677 \\
\hline Middle-n-_..... & 74 & 78 & 47 & 21 & 2 & 750 \\
\hline Lower---non & 81 & 76 & 27 & 30 & 1 & 591 \\
\hline \multicolumn{7}{|l|}{ Age of homemaker: } \\
\hline 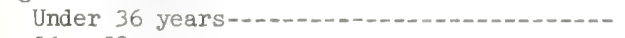 & 83 & 75 & 45 & 19 & 2 & 764 \\
\hline 36 - 50 years & 75 & 78 & 47 & 23 & 2 & 797 \\
\hline Over 50 years & 72 & 77 & 26 & 30 & 2 & 713 \\
\hline \multicolumn{7}{|l|}{ Family composition: } \\
\hline No children-_-n- & 69 & 78 & 29 & 29 & 1 & 902 \\
\hline 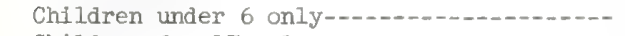 & 87 & 73 & 41 & 22 & 2 & 308 \\
\hline Children 6 - 17 only-n- & 77 & 81 & 49 & 22 & 2 & 672 \\
\hline Children in both age groups & 86 & 71 & 46 & 18 & 2 & 407 \\
\hline \multicolumn{7}{|l|}{ Size of household: } \\
\hline Small_-..... & 70 & 78 & 28 & 30 & 1 & 739 \\
\hline Medium-1.-.-n & 77 & 79 & 44 & 21 & 2 & 360 \\
\hline Large-1, & 84 & 73 & 46 & 21 & 2 & 684 \\
\hline \multicolumn{7}{|l|}{ Apple purchase levels: } \\
\hline High- & 80 & 79 & 47 & 25 & 2 & 725 \\
\hline Medium--non & 76 & 75 & 39 & 25 & 2 & 969 \\
\hline Low--1-1, & 74 & 77 & 31 & 22 & 1 & 556 \\
\hline
\end{tabular}

1 Percentages add to more than 100 because some respondents mentioned more than one occasion.

*Less than 1 percent. 
Table 38.--Homemakers who had used fresl apples raw in the past 12 months: "Now will you look at this card and tell me which of these qualities do you look for when choosing fresh apples for eating raw?" ${ }^{1}$

\begin{tabular}{|c|c|c|c|c|c|}
\hline Qualities & $\begin{array}{l}\text { United } \\
\text { States } \\
\text { total }\end{array}$ & Northeast & $\begin{array}{l}\text { North } \\
\text { Central }\end{array}$ & South & West \\
\hline & Percent & Percent & Percent & Percent & Percent \\
\hline \multirow{6}{*}{$\begin{array}{l}\text { Appearance: } \\
\text { No blemishes- } \\
\text { No bruises } \\
\text { Smooth skin } \\
\text { Shiny } \\
\text { Soft skin- }\end{array}$} & & & & & \\
\hline & 71 & 66 & 78 & 65 & 75 \\
\hline & 62 & 54 & 70 & 57 & 70 \\
\hline & 33 & 32 & 36 & 31 & 30 \\
\hline & 26 & 25 & 25 & 27 & 27 \\
\hline & 9 & 6 & 10 & 12 & 7 \\
\hline \multirow{6}{*}{$\begin{array}{l}\text { Size and shape: } \\
\text { Medium- } \\
\text { Uniform shape- } \\
\text { Large-. } \\
\text { All same size- } \\
\text { Small-... }\end{array}$} & & & & & \\
\hline & 65 & 64 & 68 & 65 & 60 \\
\hline & 14 & 13 & 15 & 12 & 17 \\
\hline & 13 & 11 & 11 & 17 & 13 \\
\hline & 6 & 7 & 5 & 6 & 8 \\
\hline & 6 & 5 & 5 & 6 & 11 \\
\hline \multicolumn{6}{|l|}{ Color: } \\
\hline 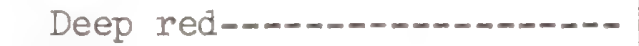 & 43 & 43 & 40 & 45 & 47 \\
\hline Bright red-n.......... & 41 & 40 & 44 & 39 & 40 \\
\hline 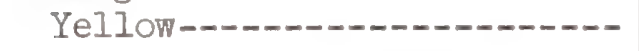 & 19 & 11 & 24 & 20 & 18 \\
\hline Part red, part green-...-.-- & 14 & 18 & 13 & 11 & 12 \\
\hline Green--ne-n & 5 & 4 & 3 & 2 & 15 \\
\hline \multicolumn{6}{|l|}{ Firmess: } \\
\hline Firm but not hard-.......-- & 62 & 67 & 63 & 58 & 60 \\
\hline Hard-_-_-_- & 24 & 26 & 24 & 19 & 30 \\
\hline Softn-n-n-n & 9 & 4 & 9 & 15 & 3 \\
\hline \multicolumn{6}{|l|}{ Taste: } \\
\hline Sweet---_- & 50 & 45 & 55 & 52 & 48 \\
\hline 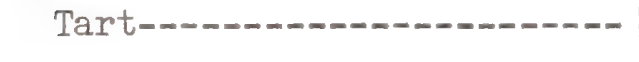 & 21 & 14 & 25 & 22 & 22 \\
\hline \multicolumn{6}{|l|}{ Juiciness: } \\
\hline 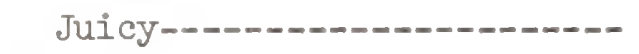 & 87 & 84 & 88 & 88 & 90 \\
\hline Dry-nes & 2 & 2 & 2 & 2 & (*) \\
\hline \multirow[t]{2}{*}{ Variety or kind of apple--.--- } & 27 & 25 & 35 & 22 & 27 \\
\hline & 2,289 & 590 & 669 & 714 & 316 \\
\hline
\end{tabular}

1 Percentages add to more than 100 because some homemakers selected more than one quality.

*Less than 1 percent. 
Table 39.--Homemakers who had used fresh apples raw in the past 12 months: "Which variety or kind of apples do you prefer for eating raw?"I

\begin{tabular}{|c|c|c|c|c|c|}
\hline Varieties preferred & $\begin{array}{l}\text { United } \\
\text { States } \\
\text { total }\end{array}$ & Northeast & $\begin{array}{l}\text { North } \\
\text { Central }\end{array}$ & South & West \\
\hline & $\underline{\text { Percent }}$ & Percent & Percent & Percent & Percent \\
\hline Delicious-nen & 58 & 44 & 57 & 62 & 72 \\
\hline Me Intosh-_... & 23 & 60 & 16 & 5 & 9 \\
\hline Jonathan & 17 & 1 & 40 & 5 & 26 \\
\hline 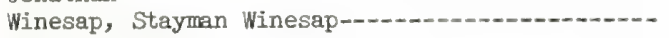 & 16 & 11 & 13 & 23 & 14 \\
\hline 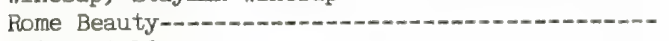 & 3 & 1 & 2 & 4 & 7 \\
\hline Grimes Golden-n- & 3 & 1 & 5 & 2 & 2 \\
\hline Cortland-....... & 2 & 7 & (*) & (*) & -- \\
\hline 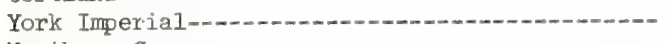 & 1 & 1 & $\langle *\rangle$ & 2 & -- \\
\hline Northern Spy-n........ & 1 & 2 & 1 & (*) & - \\
\hline Greenings m & 1 & 1 & 1 & (*) & (*) \\
\hline 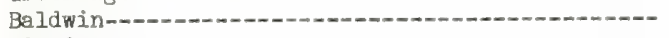 & 1 & 3 & $(*)$ & - & -- \\
\hline Pippin-1-n-men & 1 & (*) & -- & (*) & 5 \\
\hline Washington State-n- & 1 & 1 & $(*)$ & 1 & 2 \\
\hline All other varieties- & 3 & 2 & 5 & 2 & 4 \\
\hline 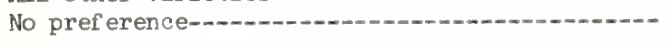 & 8 & 4 & 8 & 11 & 6 \\
\hline 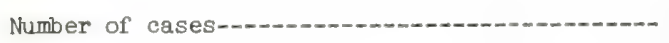 & 2,289 & 590 & 669 & 714 & 316 \\
\hline
\end{tabular}

1 Percentages add to more than 100 because some homemakers selected more than one variety.

*Less than 1 percent.

Table 40.--Hornemakers who had used fresh apples in the past 12 months: The qualities looked for and varieties chosen in fresh apples ${ }^{1}$

\begin{tabular}{|c|c|c|c|c|c|c|c|c|}
\hline \multirow{2}{*}{ Qualities } & \multicolumn{2}{|c|}{ Delicious } & \multicolumn{2}{|c|}{ McIntosh } & \multicolumn{2}{|c|}{ Jonethan } & \multicolumn{2}{|c|}{$\begin{array}{l}\text { Winesap or } \\
\text { Stayman Winesap }\end{array}$} \\
\hline & $\begin{array}{l}\text { Eating } \\
\text { raw }\end{array}$ & Cooking & $\begin{array}{l}\text { Eating } \\
\text { raw }\end{array}$ & Cooking & $\begin{array}{l}\text { rating } \\
\text { raw }\end{array}$ & Cooking & $\begin{array}{l}\text { Eating } \\
\text { raw }\end{array}$ & Cooking \\
\hline Appearance: & \multicolumn{2}{|c|}{ Percent } & \multicolumn{2}{|c|}{ Percent } & \multicolumn{2}{|c|}{ Percent } & \multicolumn{2}{|c|}{ Percent } \\
\hline No blemishes- & 73 & 60 & 71 & 57 & 79 & 62 & 69 & 55 \\
\hline No bruises-_......... & 65 & 52 & 60 & 49 & 69 & 64 & 60 & 50 \\
\hline 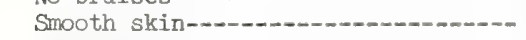 & 34 & 24 & 31 & 16 & 36 & 28 & 34 & 22 \\
\hline Shiny & 27 & 14 & 27 & 11 & 24 & 10 & 27 & 8 \\
\hline Soft skin-n-n-n & 10 & 9 & 8 & 5 & 7 & 6 & 9 & 4 \\
\hline \multicolumn{9}{|l|}{ Size and shape: } \\
\hline Medium-1-n & 64 & 56 & 67 & 45 & 71 & 60 & 66 & 59 \\
\hline Uniform shape-n. & 15 & 9 & 16 & 13 & 17 & 13 & 13 & 11 \\
\hline Large-1-n- & 15 & 23 & 10 & 21 & 9 & 15 & 11 & 14 \\
\hline All same size-n- & 6 & 4 & 7 & 9 & 6 & 9 & 8 & 9 \\
\hline Small- & 6 & 4 & 6 & 3 & 8 & 5 & 6 & 4 \\
\hline \multicolumn{9}{|l|}{ Color: } \\
\hline Deep red---1-n & 46 & 30 & 39 & 18 & 37 & 21 & 44 & 25 \\
\hline Bright red-n & 41 & 29 & 42 & 30 & 49 & 35 & 41 & 26 \\
\hline Yellow-m-n & 25 & 16 & 14 & 4 & 21 & 7 & 18 & 3 \\
\hline Part red, part green-...- & 11 & 20 & 21 & 32 & 16 & 31 & 15 & 25 \\
\hline Green-.... & 5 & 11 & 5 & 13 & 7 & 15 & 4 & 17 \\
\hline \multicolumn{9}{|l|}{ Firmess: } \\
\hline Firm, but not hard & 64 & 56 & 67 & 54 & 62 & 62 & 59 & 47 \\
\hline 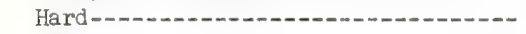 & 23 & 23 & 24 & 22 & 27 & 18 & 31 & 33 \\
\hline Soft-m-nom & 9 & 7 & 6 & 7 & 7 & 3 & 6 & 4 \\
\hline \multicolumn{9}{|l|}{ Taste: } \\
\hline 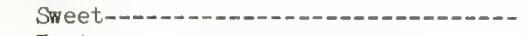 & 57 & 36 & 46 & 26 & 44 & 22 & 40 & 16 \\
\hline 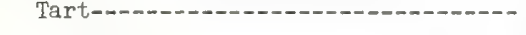 & 18 & 29 & 18 & 33 & 36 & 49 & 39 & 52 \\
\hline \multicolumn{9}{|l|}{ Juiciness: } \\
\hline Dry- & 1 & $\begin{array}{r}73 \\
3\end{array}$ & $\begin{array}{r}85 \\
1\end{array}$ & $\begin{array}{r}73 \\
5\end{array}$ & $\begin{array}{r}90 \\
1\end{array}$ & $\begin{array}{r}72 \\
3\end{array}$ & $\begin{array}{r}86 \\
2\end{array}$ & $\begin{array}{r}69 \\
4\end{array}$ \\
\hline Nuraber of cases- & 1,317 & 182 & 531 & 334 & 393 & 327 & 357 & 404 \\
\hline
\end{tabular}

1 Percentages add to more than 100 because some respondents selected more than one quality. 
Table 41.--Homemakers who had used fresh apples in the past 12 months: "During the past year have you used fresh apples for cooking or baking?"

Background characteristics

United States total--.-.--.-.---

Region:

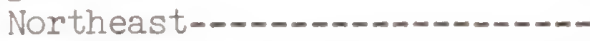

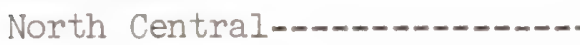

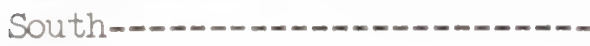

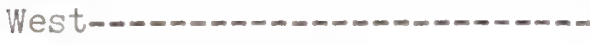

Size of commity:

Large metropolitan areas-..-Small metropolitan areas-...-Nonmetropolitan areas-.....-.-.

Family income:

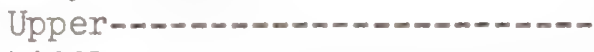

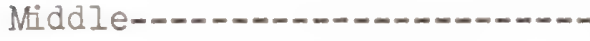

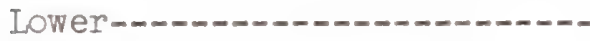

Employment of homemaker:

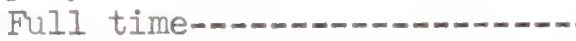

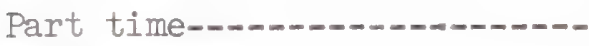

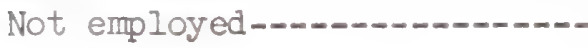

Education of homemaker:

No high school-..................

Some high school-..-..........-

High school graduate-...-.....-

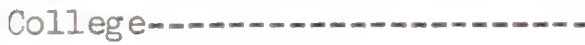

Age of homemaker:

Under 36 years--.--.---.--

36 - 50 years

Over 50 years-....-..--

Family composition:

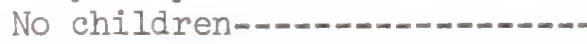

Children under 6 only-.......-.

Children 6-17 only-.-.......-.

Children in both age groups--

Size of household:

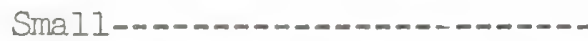

Medium--.-_-

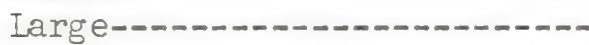

Apple purchase levels:

High-.......................... 89

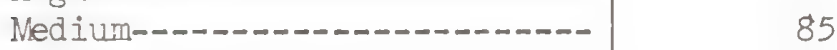

Low-_-_-

\begin{tabular}{|c|c|c|}
\hline $\begin{array}{l}\text { Have used } \\
\text { fresh apples for } \\
\text { cooking or baking } \\
\text { in past year }\end{array}$ & $\begin{array}{l}\text { Have not used } \\
\text { fresh apples for } \\
\text { cooking or baking } \\
\text { in past year }\end{array}$ & Cases \\
\hline Percent & Percent & Number \\
\hline 84 & 16 & 2,307 \\
\hline $\begin{array}{l}85 \\
89 \\
80 \\
78\end{array}$ & $\begin{array}{l}15 \\
11 \\
20 \\
22\end{array}$ & $\begin{array}{l}596 \\
675 \\
715 \\
321\end{array}$ \\
\hline $\begin{array}{l}80 \\
83 \\
88\end{array}$ & $\begin{array}{l}20 \\
17 \\
12\end{array}$ & $\begin{array}{l}891 \\
640 \\
776\end{array}$ \\
\hline $\begin{array}{l}81 \\
85 \\
84\end{array}$ & $\begin{array}{l}19 \\
15 \\
16\end{array}$ & $\begin{array}{l}680 \\
755 \\
596\end{array}$ \\
\hline $\begin{array}{l}79 \\
83 \\
85\end{array}$ & $\begin{array}{l}21 \\
17 \\
15\end{array}$ & $\begin{array}{r}500 \\
217 \\
1,590\end{array}$ \\
\hline $\begin{array}{l}85 \\
84 \\
84 \\
81\end{array}$ & $\begin{array}{l}15 \\
16 \\
16 \\
19\end{array}$ & $\begin{array}{l}540 \\
498 \\
818 \\
444\end{array}$ \\
\hline $\begin{array}{l}78 \\
85 \\
88\end{array}$ & $\begin{array}{l}22 \\
15 \\
12\end{array}$ & $\begin{array}{l}765 \\
797 \\
730\end{array}$ \\
\hline $\begin{array}{l}83 \\
78 \\
87 \\
84\end{array}$ & $\begin{array}{l}17 \\
22 \\
13 \\
16\end{array}$ & $\begin{array}{l}918 \\
310 \\
672 \\
407\end{array}$ \\
\hline $\begin{array}{l}81 \\
85 \\
85\end{array}$ & $\begin{array}{l}19 \\
15 \\
15\end{array}$ & $\begin{array}{l}753 \\
869 \\
685\end{array}$ \\
\hline $\begin{array}{l}89 \\
85 \\
76\end{array}$ & $\begin{array}{l}11 \\
15 \\
24\end{array}$ & $\begin{array}{l}728 \\
975 \\
564\end{array}$ \\
\hline
\end{tabular}


Table 42.--Homemakers who used fresh apples for cooklng and baking in the past 12 months: "Now will you look at this card and tell me which of these qualities do you look for when choosing fresh apples for cooking or baking?" 1

\begin{tabular}{|c|c|c|c|c|c|}
\hline Qualities & $\begin{array}{l}\text { United } \\
\text { States } \\
\text { total }\end{array}$ & $\begin{array}{l}\text { North - } \\
\text { east }\end{array}$ & $\begin{array}{c}\text { North } \\
\text { Central }\end{array}$ & South & West \\
\hline & Percent & Percent & Percent & Percent & Percent \\
\hline \multicolumn{6}{|l|}{ Appearance: } \\
\hline No blemishes ............... & 55 & 50 & 61 & 52 & 60 \\
\hline No bruises-_-_n-_- & 49 & 39 & 57 & 44 & 59 \\
\hline Smooth skin-_. & 19 & 14 & 21 & 21 & 22 \\
\hline 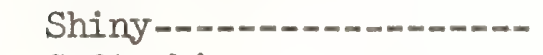 & 8 & 8 & 8 & 9 & 11 \\
\hline Soft skin-................ & 5 & 4 & 6 & 6 & 4 \\
\hline \multicolumn{6}{|l|}{ Size and Shape: } \\
\hline Medium--_-n & 51 & 44 & 53 & 57 & 46 \\
\hline Large--_-_-_- & 19 & 26 & 17 & 15 & 20 \\
\hline Uniform shape-_-_-_-_-_- & 11 & 7 & 11 & 10 & 17 \\
\hline All same size-..-...--- & 8 & 6 & 10 & 6 & 9 \\
\hline Small-_......-. & 4 & 3 & 3 & 7 & 4 \\
\hline \multicolumn{6}{|l|}{ Color: } \\
\hline Part red, part green--- & 25 & 26 & 30 & 22 & 17 \\
\hline Green-n-ns & 23 & 22 & 19 & 14 & 57 \\
\hline Bright red-_............ & 23 & 20 & 27 & 24 & 17 \\
\hline Deep red-n.n. & 19 & 18 & 16 & 27 & 13 \\
\hline Yellow- & 6 & 3 & 9 & 6 & 6 \\
\hline \multicolumn{6}{|l|}{ Firmness: } \\
\hline Firm but not hard....... & 47 & 46 & 51 & 41 & 53 \\
\hline Hard-a-n- & 27 & 30 & 20 & 33 & 26 \\
\hline Softm-n-n-n & 5 & 6 & 6 & 5 & 2 \\
\hline \multicolumn{6}{|l|}{ Taste: } \\
\hline Tart-n-n-n & 43 & 32 & 49 & 45 & 50 \\
\hline 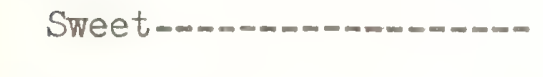 & 20 & 20 & 24 & 17 & 18 \\
\hline \multicolumn{6}{|l|}{ Juiciness: } \\
\hline 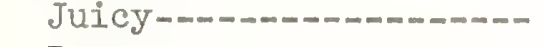 & 68 & 67 & 73 & 62 & 70 \\
\hline 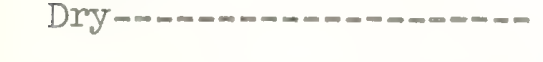 & 5 & 5 & 5 & 6 & 2 \\
\hline Variety or kind of apple- & 25 & 20 & 28 & 21 & 32 \\
\hline Number of cases-n- & 1,930 & 508 & 598 & 574 & 250 \\
\hline
\end{tabular}

1 Percentages add to more than 100 because some homemakers selected more than one quality. 
Table 43.--Homemakers who had used fresh apples for cooking or baking in the past 12 months: "Which variety or kind of apples do you prefer for cooking or baking?" 1

\begin{tabular}{|c|c|c|c|c|c|}
\hline Varieties preferred & $\begin{array}{c}\text { United States } \\
\text { total }\end{array}$ & Northeast & $\begin{array}{l}\text { North } \\
\text { Central }\end{array}$ & South & West \\
\hline & Percent & Percent & Percent & Percent & Percent \\
\hline 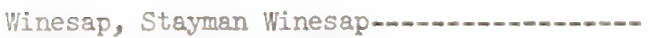 & 21 & 10 & 15 & 41 & 12 \\
\hline Mc Intosh-n-nen & 17 & 39 & 16 & 3 & 8 \\
\hline Jonathan $\ldots$ & 17 & 2 & 35 & 11 & 19 \\
\hline Delicious & 9 & 7 & 7 & 13 & 13 \\
\hline Rome Beauty & 6 & 3 & 7 & 4 & 18 \\
\hline 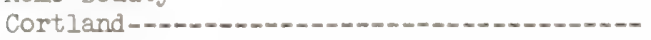 & 4 & 14 & $(*)$ & $(*)$ & - \\
\hline Greenings $-\ldots \ldots \ldots n$ & 4 & 10 & 4 & 1 & 1 \\
\hline Plppin-m & 4 & - & (*) & (*) & 30 \\
\hline Baldwin $\ldots \ldots \ldots m-n \ldots$ & 3 & 8 & 1 & 1 & $(*)$ \\
\hline Northern Spy-1-n & 3 & 6 & 5 & $-\infty$ & 1 \\
\hline 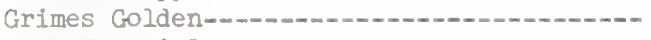 & 2 & 1 & 3 & 1 & -- \\
\hline 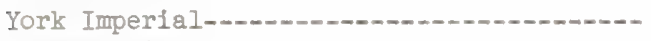 & 2 & 1 & -- & 5 & (*) \\
\hline Gravenstein & 1 & (*) & - & - & 8 \\
\hline Wealthy & 1 & (*) & 1 & - & - \\
\hline Transparent & 1 & - & 3 & - & 1 \\
\hline All other varleties & 4 & 4 & 4 & 4 & 4 \\
\hline 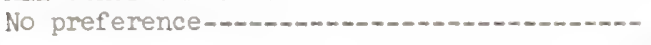 & 14 & 12 & 17 & 16 & 9 \\
\hline Number of cases.n. & 1,930 & 508 & 598 & 574 & 250 \\
\hline
\end{tabular}

1 Percentages may add to more than 100 because some respondents named more than one variety.

* Less than 1 percent.

Table 44.--Homemakers who had purchased fresh apples in the past 12 months but had not used them for cooking or baking: "How come you haven't used fresh apples for cooking or baking?"I

\begin{tabular}{|c|c|}
\hline Reasons & $\begin{array}{c}\text { United States } \\
\text { total }\end{array}$ \\
\hline & Percent \\
\hline Prefer raw apples-1-n & 23 \\
\hline No time to bake & 21 \\
\hline Not worth the effort & 16 \\
\hline 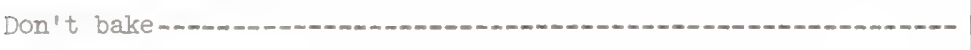 & 12 \\
\hline Buy canned applesauce-n- & 10 \\
\hline 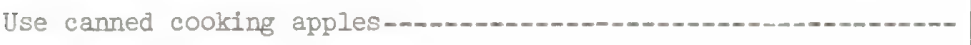 & 10 \\
\hline Little or no cookling experience-n. & 10 \\
\hline 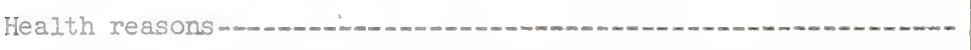 & 8 \\
\hline Buy store bought desserts & 6 \\
\hline Don't especially like desserts-n & 6 \\
\hline Buy frczer apple pies-n- & 6 \\
\hline Too expensive to buy apples-n & 4 \\
\hline All other reasons & 3 \\
\hline Not speclfied-1-n-- & 1 \\
\hline Number of cases-n..-- & 377 \\
\hline
\end{tabular}




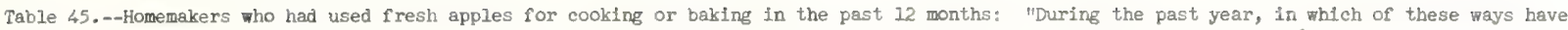
you used fresh apples for cooking or baking? Homemade applesauce, baked apples, apple cake...?"I

\begin{tabular}{|c|c|c|c|c|c|c|c|c|}
\hline Background characteristics & $\begin{array}{l}\text { Apple } \\
\text { pie }\end{array}$ & $\begin{array}{l}\text { Baked } \\
\text { apples }\end{array}$ & $\begin{array}{c}\text { Homemade } \\
\text { applesauce }\end{array}$ & $\begin{array}{l}\text { Apple } \\
\text { cake }\end{array}$ & $\begin{array}{l}\text { Other } \\
\text { desserts }\end{array}$ & $\begin{array}{l}\text { Fried } \\
\text { apples }\end{array}$ & $\begin{array}{l}\text { All other } \\
\text { ways }\end{array}$ & Cases \\
\hline & Percent & Percent & Percent & Percent & Percent & Percent & Percent & Number \\
\hline United States total-nen & 84 & 66 & 64 & 30 & 38 & 6 & 3 & 1,930 \\
\hline $\begin{array}{l}\text { Region: } \\
\text { Northeast-1- } \\
\text { North Central- } \\
\text { South- } \\
\text { West.-. }\end{array}$ & $\begin{array}{l}79 \\
89 \\
85 \\
76\end{array}$ & $\begin{array}{l}65 \\
62 \\
69 \\
70\end{array}$ & $\begin{array}{l}78 \\
73 \\
44 \\
60\end{array}$ & $\begin{array}{l}37 \\
34 \\
22 \\
28\end{array}$ & $\begin{array}{l}36 \\
44 \\
35 \\
31\end{array}$ & $\begin{array}{r}2 \\
7 \\
10 \\
2\end{array}$ & $\begin{array}{l}2 \\
5 \\
3 \\
4\end{array}$ & $\begin{array}{l}508 \\
598 \\
574 \\
250\end{array}$ \\
\hline $\begin{array}{l}\text { Size of community: } \\
\text { Large metropolitan areas } \\
\text { Small metropolitan areas } \\
\text { Nonnetropolitan areas }\end{array}$ & $\begin{array}{l}76 \\
87 \\
89\end{array}$ & $\begin{array}{l}66 \\
67 \\
64\end{array}$ & $\begin{array}{l}66 \\
66 \\
61\end{array}$ & $\begin{array}{l}27 \\
31 \\
32\end{array}$ & $\begin{array}{l}28 \\
43 \\
44\end{array}$ & $\begin{array}{l}5 \\
6 \\
6\end{array}$ & $\begin{array}{l}3 \\
4 \\
3\end{array}$ & $\begin{array}{l}717 \\
531 \\
682\end{array}$ \\
\hline $\begin{array}{l}\text { Age of homemaker: } \\
\text { Under } 36 \text { years } \\
36 \text { - } 50 \text { years } \\
\text { Over } 50 \text { years }\end{array}$ & $\begin{array}{l}84 \\
87 \\
80\end{array}$ & $\begin{array}{l}54 \\
68 \\
75\end{array}$ & $\begin{array}{l}52 \\
66 \\
74\end{array}$ & $\begin{array}{l}27 \\
33 \\
30\end{array}$ & $\begin{array}{l}37 \\
41 \\
35\end{array}$ & $\begin{array}{l}6 \\
5 \\
7\end{array}$ & $\begin{array}{l}3 \\
3 \\
4\end{array}$ & $\begin{array}{l}594 \\
677 \\
646\end{array}$ \\
\hline $\begin{array}{l}\text { Family composition: } \\
\text { No children- } \\
\text { Children under } 6 \text { only- } \\
\text { Children } 6-17 \text { only } \\
\text { Children in both age groups }\end{array}$ & $\begin{array}{l}79 \\
84 \\
86 \\
89\end{array}$ & $\begin{array}{l}72 \\
50 \\
68 \\
61\end{array}$ & $\begin{array}{l}71 \\
51 \\
64 \\
59\end{array}$ & $\begin{array}{l}27 \\
28 \\
36 \\
29\end{array}$ & $\begin{array}{l}33 \\
40 \\
40 \\
42\end{array}$ & $\begin{array}{l}6 \\
7 \\
6 \\
5\end{array}$ & $\begin{array}{l}4 \\
5 \\
2 \\
3\end{array}$ & $\begin{array}{l}761 \\
243 \\
583 \\
343\end{array}$ \\
\hline $\begin{array}{l}\text { Size of household: } \\
\text { Small } \\
\text { Medium- Large- }\end{array}$ & $\begin{array}{l}77 \\
84 \\
90\end{array}$ & $\begin{array}{l}73 \\
64 \\
61\end{array}$ & $\begin{array}{l}70 \\
61 \\
62\end{array}$ & $\begin{array}{l}26 \\
29 \\
35\end{array}$ & $\begin{array}{l}32 \\
39 \\
42\end{array}$ & $\begin{array}{l}0 \\
7 \\
5\end{array}$ & $\begin{array}{l}4 \\
3 \\
4\end{array}$ & $\begin{array}{l}610 \\
735 \\
585\end{array}$ \\
\hline $\begin{array}{l}\text { Apple purchase levels: } \\
\text { High } \\
\text { Mediumn }\end{array}$ & $\begin{array}{l}89 \\
81 \\
80\end{array}$ & $\begin{array}{l}70 \\
65 \\
60\end{array}$ & $\begin{array}{l}73 \\
60 \\
61\end{array}$ & $\begin{array}{l}36 \\
29 \\
25\end{array}$ & $\begin{array}{l}44 \\
38 \\
29\end{array}$ & $\begin{array}{l}6 \\
6 \\
5\end{array}$ & $\begin{array}{l}4 \\
3 \\
4\end{array}$ & $\begin{array}{l}645 \\
824 \\
430\end{array}$ \\
\hline
\end{tabular}

1 Percentages add to more than 100 because some respondents mentioned more than one way.

Table 46.--Homemakers who had used fresh apples for cooking or baking in the past 12 months: "What percentage of all the fresh apples bought during the past year did you use for cooking or baking?"1

\begin{tabular}{|c|c|c|c|c|c|}
\hline Background characteristics & $\begin{array}{l}75 \text { percent } \\
\text { and over }\end{array}$ & $\begin{array}{l}50 \text { to } 74 \\
\text { percent }\end{array}$ & $\begin{array}{l}25 \text { to } 49 \\
\text { percent }\end{array}$ & $\begin{array}{l}\text { Less than } \\
25 \text { percent }\end{array}$ & Caser \\
\hline & Percent & Percent & Percent & Percent & Number \\
\hline United States total- & 11 & 28 & 29 & 31 & 1,930 \\
\hline $\begin{array}{l}\text { Region: } \\
\text { Northeast- } \\
\text { North Central- } \\
\text { South- }\end{array}$ & $\begin{array}{r}12 \\
13 \\
9 \\
9\end{array}$ & $\begin{array}{l}31 \\
31 \\
25 \\
21\end{array}$ & $\begin{array}{l}27 \\
27 \\
35 \\
22\end{array}$ & $\begin{array}{l}29 \\
28 \\
31 \\
47\end{array}$ & $\begin{array}{l}508 \\
598 \\
574 \\
250\end{array}$ \\
\hline $\begin{array}{l}\text { Size of community: } \\
\text { Large metropolitan areas } \\
\text { Small metropolitan areas } \\
\text { Nonnetropolitan areas }\end{array}$ & $\begin{array}{r}9 \\
11 \\
14\end{array}$ & $\begin{array}{l}24 \\
30 \\
32\end{array}$ & $\begin{array}{l}27 \\
29 \\
30\end{array}$ & $\begin{array}{l}39 \\
30 \\
24\end{array}$ & $\begin{array}{l}717 \\
531 \\
682\end{array}$ \\
\hline $\begin{array}{l}\text { Family income: } \\
\text { Upper- } \\
\text { Middle-1ower- }\end{array}$ & $\begin{array}{r}8 \\
10 \\
14\end{array}$ & $\begin{array}{l}23 \\
28 \\
32\end{array}$ & $\begin{array}{l}31 \\
32 \\
27\end{array}$ & $\begin{array}{l}38 \\
29 \\
26\end{array}$ & $\begin{array}{l}554 \\
640 \\
500\end{array}$ \\
\hline $\begin{array}{l}\text { Employment of homemaker: } \\
\text { Full time- } \\
\text { Part time- employed- } \\
\text { Not }\end{array}$ & $\begin{array}{r}9 \\
12 \\
12\end{array}$ & $\begin{array}{l}25 \\
31 \\
28\end{array}$ & $\begin{array}{l}31 \\
33 \\
28\end{array}$ & $\begin{array}{l}35 \\
24 \\
31\end{array}$ & $\begin{array}{r}396 \\
181 \\
1,353\end{array}$ \\
\hline $\begin{array}{l}\text { Education of homemaker: } \\
\text { No high school } \\
\text { Some high school } \\
\text { High school graduate } \\
\text { College }\end{array}$ & $\begin{array}{l}14 \\
11 \\
10 \\
11\end{array}$ & $\begin{array}{l}33 \\
26 \\
26 \\
28\end{array}$ & $\begin{array}{l}28 \\
28 \\
30 \\
29\end{array}$ & $\begin{array}{l}24 \\
34 \\
34 \\
32\end{array}$ & $\begin{array}{l}459 \\
417 \\
687 \\
360\end{array}$ \\
\hline $\begin{array}{l}\text { Age of homemaker: } \\
\text { Undex } 36 \text { years- } \\
36 \text { - } 50 \text { years } \\
\text { Over } 50 \text { years }\end{array}$ & $\begin{array}{r}6 \\
7 \\
20\end{array}$ & $\begin{array}{l}21 \\
28 \\
35\end{array}$ & $\begin{array}{l}30 \\
34 \\
23\end{array}$ & $\begin{array}{l}42 \\
31 \\
20\end{array}$ & $\begin{array}{l}594 \\
677 \\
646\end{array}$ \\
\hline $\begin{array}{l}\text { Family composition: } \\
\text { No children- } \\
\text { Children under } 6 \text { only- } \\
\text { Children } 6-17 \text { only- } \\
\text { Children in both age groups. }\end{array}$ & $\begin{array}{r}18 \\
9 \\
7 \\
4\end{array}$ & $\begin{array}{l}32 \\
21 \\
26 \\
27\end{array}$ & $\begin{array}{l}24 \\
26 \\
35 \\
31\end{array}$ & $\begin{array}{l}25 \\
43 \\
32 \\
37\end{array}$ & $\begin{array}{l}761 \\
243 \\
583 \\
343\end{array}$ \\
\hline $\begin{array}{l}\text { Size of household: } \\
\text { Small } \\
\text { Medium } \\
\text { Large- }\end{array}$ & $\begin{array}{r}18 \\
10 \\
6\end{array}$ & $\begin{array}{l}32 \\
26 \\
26\end{array}$ & $\begin{array}{l}24 \\
31 \\
31\end{array}$ & $\begin{array}{l}25 \\
33 \\
36\end{array}$ & $\begin{array}{l}610 \\
735 \\
585\end{array}$ \\
\hline $\begin{array}{l}\text { Apple purchase levels: } \\
\text { High- } \\
\text { Medium } \\
\text { Low- }\end{array}$ & $\begin{array}{r}11 \\
8 \\
17\end{array}$ & $\begin{array}{l}29 \\
28 \\
27\end{array}$ & $\begin{array}{l}32 \\
28 \\
24\end{array}$ & $\begin{array}{l}27 \\
35 \\
31\end{array}$ & $\begin{array}{l}645 \\
824 \\
430\end{array}$ \\
\hline
\end{tabular}

\footnotetext{
1 Percentages may add to less than 100 because answers were not obtained from all homemakers.
} 
Table 47.--Homemakers who had used fresh apples for cooking or baking in the past 12 months: "Do you sometimes buy a certain variety or kind of apple especially for cooking or baking?" If no, "Why not?" ${ }^{1}$

\begin{tabular}{|c|c|}
\hline Replies & $\begin{array}{c}\text { United States } \\
\text { total }\end{array}$ \\
\hline & Percent \\
\hline Do buy & 73 \\
\hline Do not buy & 27 \\
\hline Iike all purpose apples- & 8 \\
\hline Use whatever is on hand & 6 \\
\hline Iike the qualities of eating apples for all purposes.....- & 4 \\
\hline Not fussy about kind & 3 \\
\hline Just buy, use what is liked & 2 \\
\hline Buy cheapest for cooking & 2 \\
\hline See no difference-mon & 1 \\
\hline Raise own-m-nen & 1 \\
\hline Easier to get one kind-n. & 1 \\
\hline Not available $-\cdots+\cdots$ & 1 \\
\hline Number of cases-nen & 1,930 \\
\hline
\end{tabular}

1 Percentages add to more than the group total because some respondents mentioned more than 1 reason.

Table 48.--Homemakers who had purchased fresh apples in the past 12 months: "Lo you have any difficulty in finding good fresh apples for cooking or eating raw?" If yes--"Is that at any particular time of year?" If so-"At what particular time of year does this occur?"I

\begin{tabular}{|c|c|}
\hline Replies & Percent \\
\hline 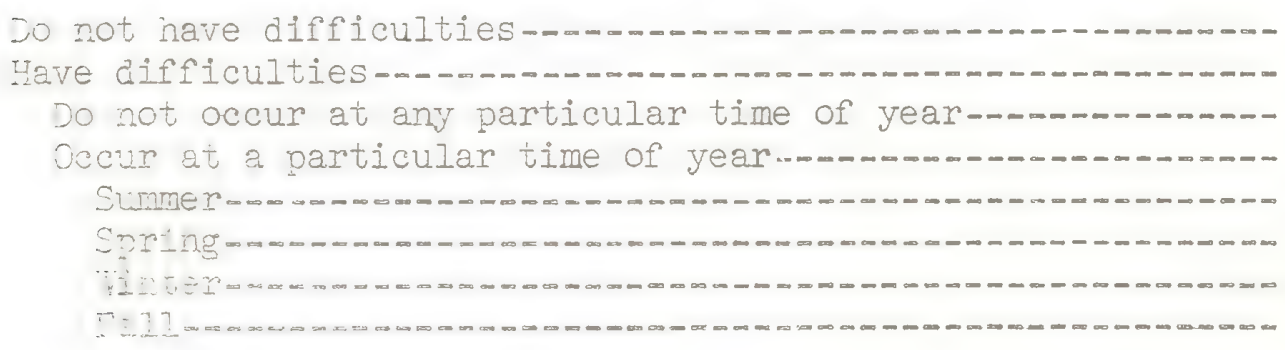 & $\begin{array}{r}86 \\
14 \\
3 \\
11 \\
6 \\
4 \\
2 \\
2\end{array}$ \\
\hline 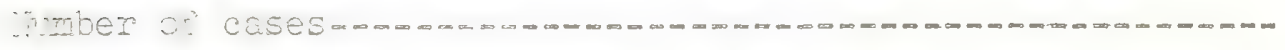 & 2,307 \\
\hline
\end{tabular}

aranteges add to nore then the group total because some respondents -orticued -om - - an a seson. 
Table 49.--Homemakers who had difficulty in finding good fresh apples for cooking or eating raw: "Is this with any special variety or kind of apple?"I

Replies

United States total

Percent

DOES NOT OCCUR WITH ANY SPECIFIC VARIETY_-...................

OCCURS WITH A SPECIFIC VARIETY-_.

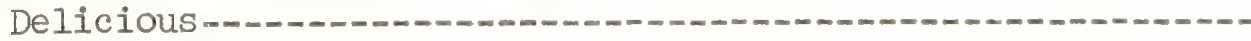

Jonathan-

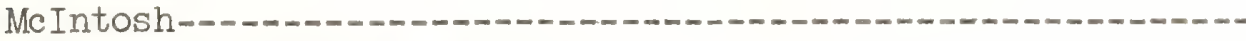

Winesap or Stayman Winesap-a

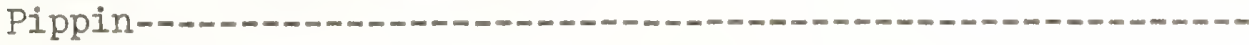

Rome Beauty

Northern Spy

Greenings

Grimes Golden

Washington State

Baldwin-

All other varieties

Not ascertained

20

7

6

3

2

2

2

2

2

1

1

1

2

5

Number of cases

1 Percentages add to more than the group total because some respondents mentioned more than one variety.

Table 50.--Homemakers who had purchased fresh apples in the past 12 months: "Have you been disappointed in apples that you have bought during the past year?"

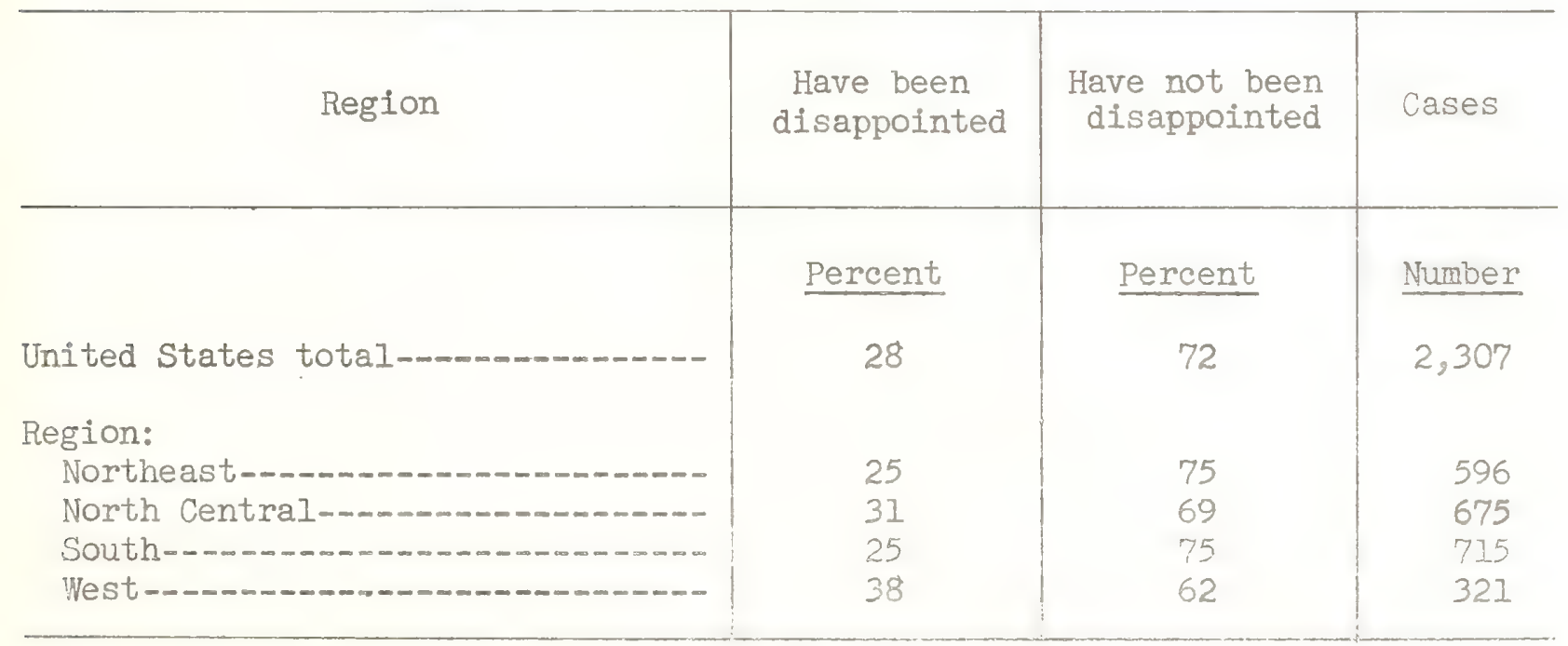


Table 51.--Homemakers who said they had been disappointed with the apples bought in the past 12 months: "In what ways?"I

\begin{tabular}{|c|c|}
\hline Replies & $\begin{array}{c}\text { United States } \\
\text { total }\end{array}$ \\
\hline & Percent \\
\hline Interior blemishes and deterioration & 25 \\
\hline Dry & 22 \\
\hline Soft, mushy, soggy-no & 21 \\
\hline No taste, flat-n & 16 \\
\hline Bruised, blemished-ne & 15 \\
\hline Mealy, powdery, pulpy-n & 13 \\
\hline Complete spoilage-no & 11 \\
\hline Sour, not sweetmo & 11 \\
\hline 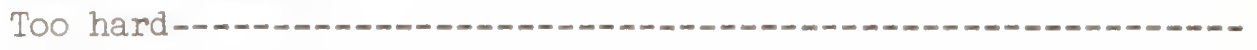 & 10 \\
\hline Dislike the taste-n & 7 \\
\hline Dislike the quality-no & 7 \\
\hline Spoiled quickly, easily-n... & 6 \\
\hline Not fresh, crisp-n-n-n & 4 \\
\hline Skin tough, thick-n & 4 \\
\hline Wormy & 4 \\
\hline 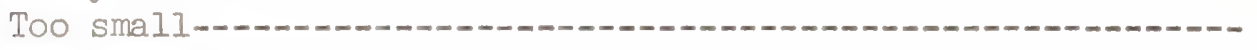 & 3 \\
\hline Musty taste-n-n & 1 \\
\hline All other reasons & 6 \\
\hline Number of cases-n-n- & 655 \\
\hline
\end{tabular}

1 Percentages add to more than 100 because some respondents gave more than one answer.

Table 52.--Homemakers who said they had been disappointed with apples bought in the past 12 months: "Where did you buy the apples you did not like?"I

\section{Point of purchase}

Homemakers responding

Percent

Supermarket-1Grocery store-1-1.Roadside stand-_. Peddler-1. Farmer's market_-_..._. Orchard, farm-........ All other places-_.nNot ascertained

Number of cases

1 Percentages add to more than 100 because some respondents named more than one point of purchase. 
Table 53.--Homemakers who had bought fresh apples in the past 12 months: "Have you bought something else at anytime in the past year when you would have preferred to buy apples? What did you buy (last time)?"I

Replies

Homemakers

who responded

Percent

HAVE NOT BOUGHT SUBSTITUTES

86

HAVE BOUGHT SUBSTITUTES-

Bananas

Oranges

Grapes

Pears

Peaches

Plums or fresh prunes

Other fresh fruits or berries

Other substitutes

Number of

cases

1 Percentages add to more than their group total because some respondents named more than 1 fruit.

Table 54.--Homemakers who had bought substitutes for apples in the past 12 months when they would have preferred to buy apples: "What were the circumstances?" ${ }^{3}$

Circumstance

United States total

Percent

Not available

31

21

Disliked the appearance

Disliked the appearance-19
Bruised, blemished, rotten

Poor quality-......

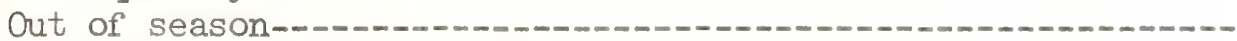

Soft, mushy, not firm-....

Disliked the size

Disliked the color

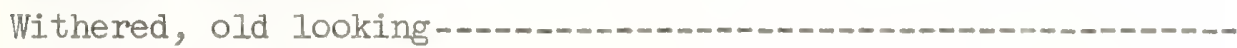

Too dry, dried up-

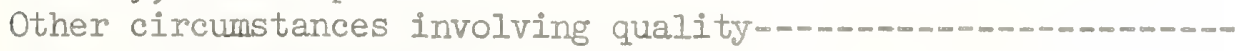

All other circumstances

Number of cases.

I Percentages add to more than 100 because some respondents gave more than 1 circumstance. 
Table 55.--All homemakers: Proportions who had made applesauce and/or purchased processed applesauce

\begin{tabular}{|c|c|c|c|c|c|}
\hline $\begin{array}{c}\text { Background } \\
\text { characteristics }\end{array}$ & $\begin{array}{l}\text { Used home- } \\
\text { made only }\end{array}$ & $\begin{array}{c}\text { Used } \\
\text { processed } \\
\text { only }\end{array}$ & $\begin{array}{l}\text { Used } \\
\text { both } \\
\text { kinds }\end{array}$ & $\begin{array}{l}\text { Used } \\
\text { neither } \\
\text { kind }\end{array}$ & Cases \\
\hline & Percent & Percent & Percent & Percent & Number \\
\hline United States total------- & 14 & 35 & 36 & 15 & 2,454 \\
\hline \multicolumn{6}{|l|}{ Region: } \\
\hline Northeast_................ & 14 & 31 & 48 & 7 & 637 \\
\hline North Central-.......- & 18 & 28 & 44 & 10 & 716 \\
\hline South-n-n-- & 11 & 40 & 23 & 26 & 742 \\
\hline West-- & 12 & 43 & 29 & 16 & 359 \\
\hline \\
\hline Large metropolitan areas- & 11 & 40 & 39 & 10 & 945 \\
\hline Smal1 metropolitan areas- & 11 & 35 & 41 & 13 & 676 \\
\hline Nonmetropolitan areas---- & 19 & 28 & 31 & 22 & 833 \\
\hline \multicolumn{6}{|l|}{ Family income: } \\
\hline Upper-........................ & 11 & 42 & 41 & 6 & 700 \\
\hline Middle $\ldots \ldots \ldots$ & 13 & 35 & 39 & 13 & 807 \\
\hline Lower---- - & 17 & 28 & 29 & 26 & 654 \\
\hline \multicolumn{6}{|l|}{$\begin{array}{l}\text { Education of homemaker: } \\
\text { No high school- }\end{array}$} \\
\hline No high school-_.....-. & 18 & 26 & 31 & 25 & 603 \\
\hline Some high school-....... & 12 & 38 & 33 & 17 & 519 \\
\hline High school graduate-..-- & 13 & 38 & 39 & 10 & 860 \\
\hline College $\ldots \ldots$ & 14 & 36 & 42 & 8 & 464 \\
\hline \multicolumn{6}{|l|}{ Age of homemaker: } \\
\hline Under 36 years.............. & 8 & 49 & 31 & 12 & 791 \\
\hline 36 - 50 years $\ldots \ldots \ldots$ & 13 & 33 & 40 & 14 & 834 \\
\hline Over 50 years & 21 & 23 & 38 & 18 & 812 \\
\hline \multicolumn{6}{|l|}{ Family composition: } \\
\hline No children-...-. & 19 & 28 & 34 & 19 & 1,025 \\
\hline Children under 6 only---- & 9 & 51 & 30 & 10 & 318 \\
\hline $\begin{array}{l}\text { Children } 6-17 \text { only } \\
\text { Children in both age }\end{array}$ & 13 & 33 & 42 & 12 & 691 \\
\hline groups $-\ldots-\ldots \ldots \ldots$ & 9 & 42 & 39 & 10 & 420 \\
\hline \multicolumn{6}{|l|}{ Size of household: } \\
\hline Sma II $1-\infty-\infty-\infty-\infty-\infty+\infty-\infty-\infty-\infty$ & 18 & 29 & 32 & 21 & 851 \\
\hline Med 1 um $-\infty-\infty+\infty-\infty-\infty-\infty-\infty-\infty$ & 12 & 38 & 38 & 12 & 898 \\
\hline Large $---\infty-\infty-\infty-\infty-------\infty--$ & 11 & 38 & 40 & 11 & 705 \\
\hline
\end{tabular}


Table 56.--Homemakers who had purchased processed applesauce in the past 12 months: "How do you generally use the applesauce you buy?"I

\begin{tabular}{|c|c|}
\hline Uses & $\begin{array}{l}\text { United } \\
\text { States } \\
\text { total }\end{array}$ \\
\hline & Percent \\
\hline As a side dish with meat & 62 \\
\hline As a dessert-n & 42 \\
\hline In recipes for cake, cookies, etc & 12 \\
\hline As garnish on meat-n. & 8 \\
\hline As a breakfast fruit & 5 \\
\hline With pancakes & 5 \\
\hline On toast, bread & 4 \\
\hline As a snack-n. & 3 \\
\hline As baby food & 2 \\
\hline All other usesmon & 1 \\
\hline Number of cases............... & 1,747 \\
\hline
\end{tabular}

1 Pereentages add to more than 100 because some respondents mentioned more than one use.

Table 57.--Homemakers who had purchased processed applesauce in the past 12 months:

"Which do you prefer, homemade applesauce or the kind you can buy in the store?"

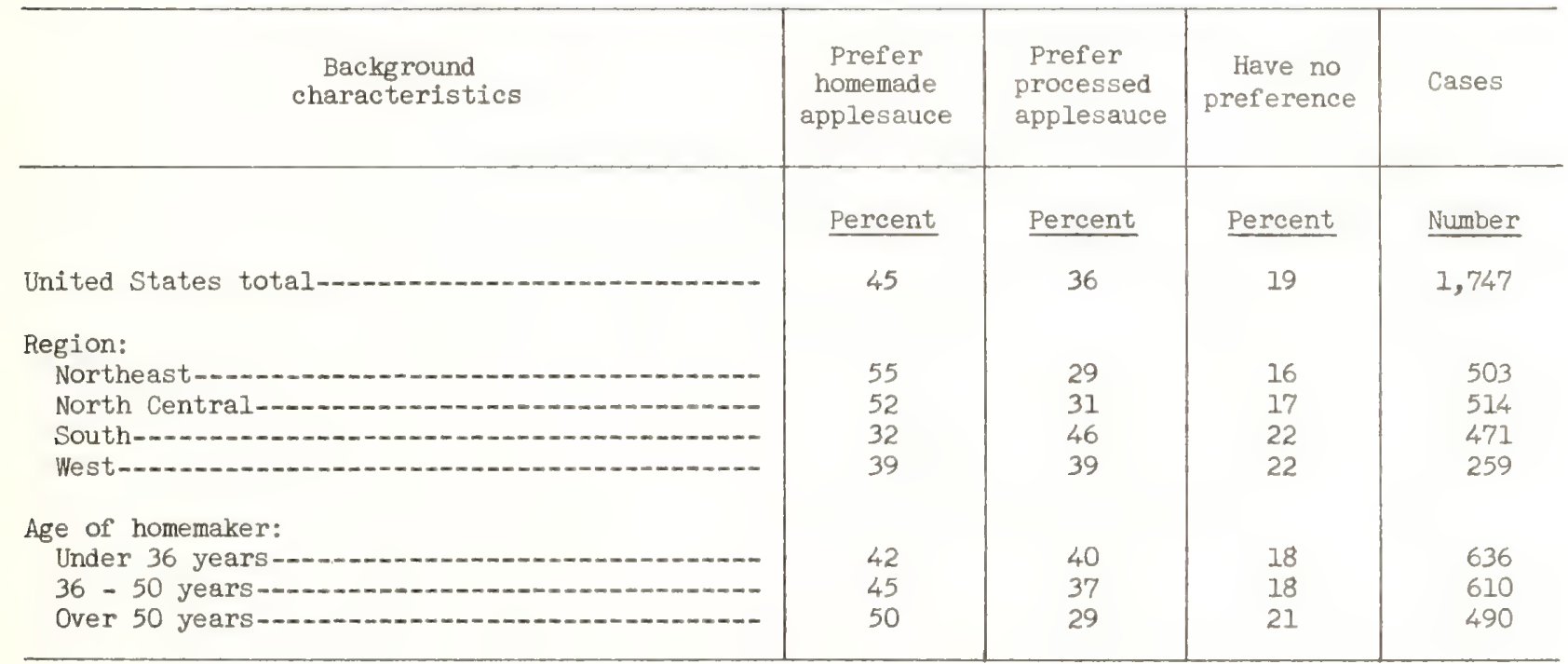


Table 58.--Homemakers who had purchased processed applesauce in the past 12 months and preferred the processed; preferred the homemade: "Why is that?"1

\begin{tabular}{|c|c|c|}
\hline Reasons for preference & $\begin{array}{c}\text { Preferred processed } \\
\text { applesauce }\end{array}$ & $\begin{array}{c}\text { Preferred homemade } \\
\text { applesauce }\end{array}$ \\
\hline & Percent & Percent \\
\hline More convenient-n. & 63 & - \\
\hline Iess expensive & 12 & 4 \\
\hline Better taste-n-n- & 11 & 20 \\
\hline Better made------ & 11 & $-\infty$ \\
\hline Smoother & 9 & 2 \\
\hline Other taste factors-n-n & 5 & 11 \\
\hline 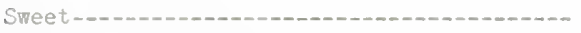 & 3 & 8 \\
\hline 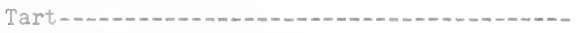 & 3 & 5 \\
\hline 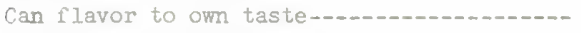 & 2 & 30 \\
\hline Just like it better-n & 2 & 3 \\
\hline Never tasted homemade-n- & 2 & - \\
\hline 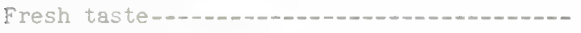 & 1 & 20 \\
\hline Color & 1 & 3 \\
\hline Other consistency and texture reasons....... & 1 & 2 \\
\hline Tangy & 1 & 12 \\
\hline 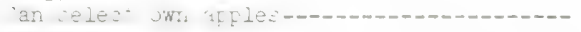 & -- & 6 \\
\hline runiter-- & - & 3 \\
\hline 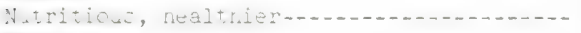 & -- & 1 \\
\hline Gringer---- - - - - - - - - - - - - - - - - - - - - - & - & 1 \\
\hline 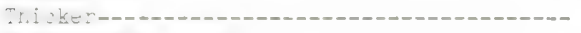 & -- & 5 \\
\hline 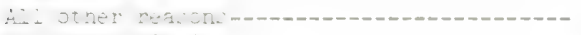 & 4 & 3 \\
\hline 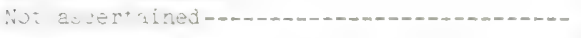 & 1 & $I$ \\
\hline 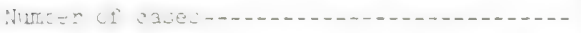 & 024 & 795 \\
\hline
\end{tabular}

1 Percentages add to more than 100 because some respondents gave more than one reason for preference.

Table 59.--All homemakers: "How would you describe the way good applesauce should look and taste?"I

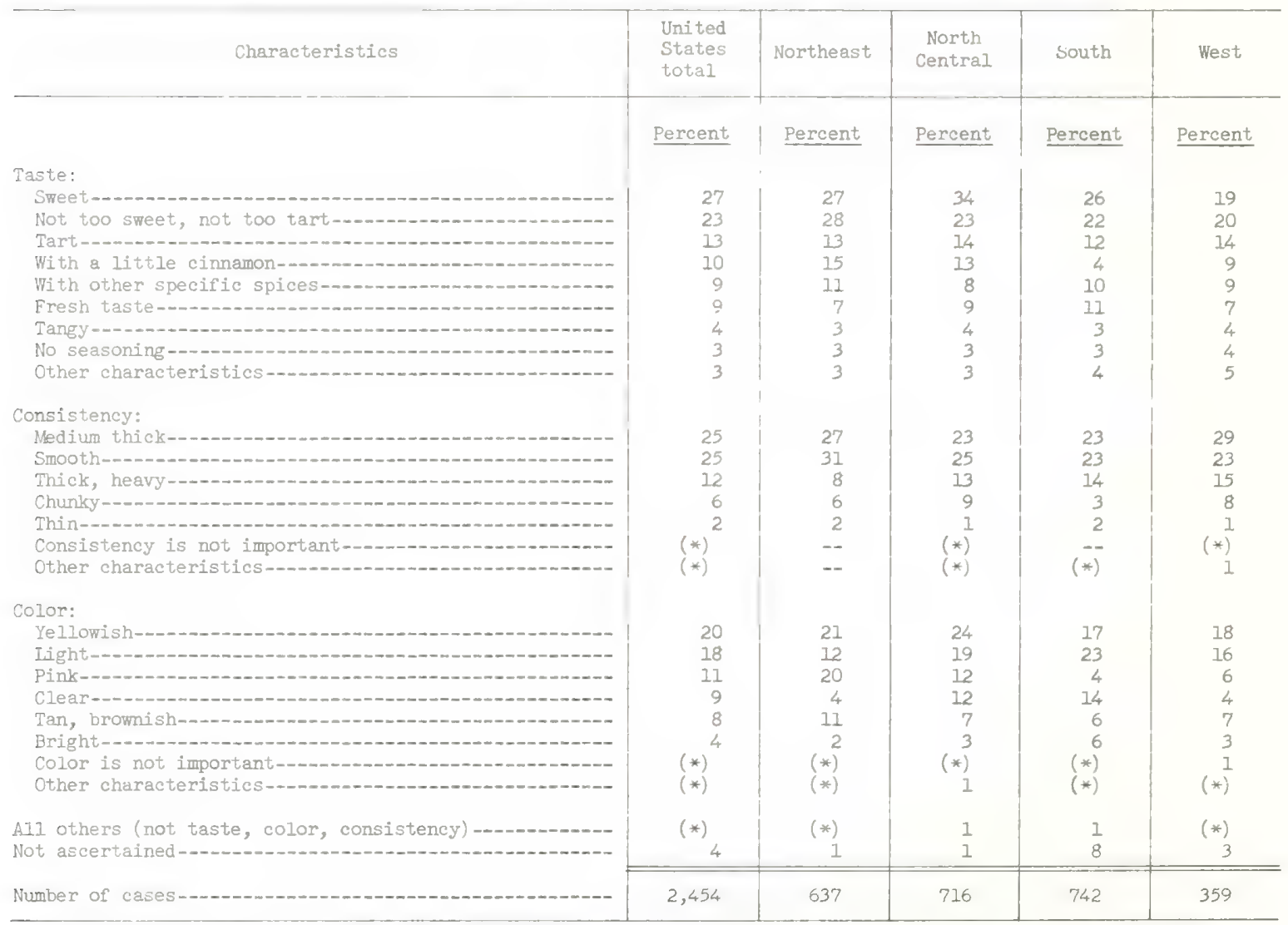

1 Percentages add to more than 100 because some respondents mentioned more than one characteristic.

* Less than 1 percent. 
Table 60.--Homemakers' opinions about the consistency and color good applesauce should have ${ }^{1}$

\begin{tabular}{|c|c|c|c|c|c|c|c|}
\hline Characteristics & Unaided $^{2}$ & Aided $^{2}$ & $\begin{array}{l}\text { Total } \\
\text { aided and } \\
\text { unaided }\end{array}$ & Northeast & $\begin{array}{l}\text { North } \\
\text { Central }\end{array}$ & South & West \\
\hline Consistency: & Percent & Percent $^{3}$ & Percent & Percent & Percent & Percent & Percent \\
\hline 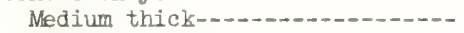 & 25 & 25 & 49 & 51 & 48 & 49 & 50 \\
\hline Smooth-m-n-men & 25 & 9 & 35 & 44 & 34 & 30 & 29 \\
\hline 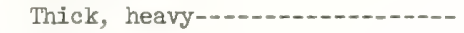 & 12 & 12 & 24 & 21 & 26 & 26 & 26 \\
\hline Chunky-- & 6 & 3 & 9 & 7 & 14 & 4 & 12 \\
\hline 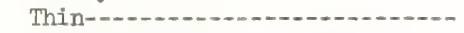 & 2 & 2 & 3 & 4 & 2 & 3 & 5 \\
\hline $\begin{array}{l}\text { Consistency is not important-.. } \\
\text { Other consistency character- }\end{array}$ & (*) & 2 & 2 & 1 & 1 & 2 & 3 \\
\hline 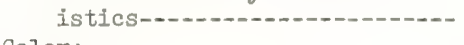 & (*) & 1 & 1 & 1 & 1 & 1 & 1 \\
\hline Color: & & & & & & & \\
\hline Yellowish-n-n. & 20 & 14 & 35 & 34 & 36 & 30 & 42 \\
\hline 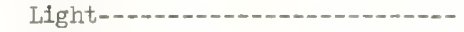 & 18 & 5 & 23 & 14 & 24 & 30 & 22 \\
\hline 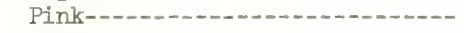 & 11 & 4 & 15 & 26 & 15 & 7 & 9 \\
\hline Clear $\cdots+\cdots+\cdots$ & 9 & 2 & 12 & 4 & 14 & 17 & 9 \\
\hline 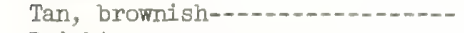 & 8 & 4 & 12 & 17 & 10 & 9 & 12 \\
\hline Bright-n-n-m & 4 & 1 & 4 & 3 & 3 & 7 & 4 \\
\hline Color is not important-.....- & $(*)$ & 5 & 5 & 6 & 5 & 5 & 8 \\
\hline Other color characteristics---- & $(*)$ & $I$ & 1 & 1 & 2 & 1 & (*) \\
\hline Number of cases-.............. & 2,454 & 2,454 & 2,454 & 637 & 716 & 742 & 359 \\
\hline
\end{tabular}

1 Percentages add to more than 100 because some respondents mentioned more than one characteristic.

2 Homemakers were asked, "How would you describe the way good applesauce should look and taste?"

(unaided). Those who did not mention color or consistency were then asked, "What about color?" "What about consistency?" (afded) (see table 59).

${ }^{3}$ Percentages add to less than 100 because it was not necessary to ask all respondents Q. 29b, c,

* Less than 1 percent

Table 61.--Homemakers who had indicated a preference for processed or homemade applesauce: "How would you describe the way good applesauce should look and taste?"I

\begin{tabular}{|c|c|c|}
\hline \multirow[b]{2}{*}{ Description } & \multicolumn{2}{|c|}{ Homemakers who preferred } \\
\hline & $\begin{array}{l}\text { Homemade } \\
\text { applesauce }\end{array}$ & $\begin{array}{l}\text { Processed } \\
\text { applesauce }\end{array}$ \\
\hline $\begin{array}{l}\text { Taste: } \\
\text { Sweet- } \\
\text { Not too sweet, not too tart- a little cinnamon } \\
\text { Wart a } \\
\text { With other spices } \\
\text { Fresh taste } \\
\text { Tangy- } \\
\text { No seasoning } \\
\text { Other characteristics }\end{array}$ & $\begin{array}{l}\text { Percent }^{2} \\
27 \\
22 \\
17 \\
17 \\
16 \\
10 \\
5 \\
2 \\
4\end{array}$ & $\begin{array}{l}\text { Percent }^{2} \\
29 \\
27 \\
6 \\
12 \\
6 \\
10 \\
3 \\
3 \\
3\end{array}$ \\
\hline $\begin{array}{l}\text { Consistency: } \\
\text { Medium thick- } \\
\text { Smooth } \\
\text { Thick, heavy } \\
\text { Thinky } \\
\text { Consistency is not important } \\
\text { Other characteristics }\end{array}$ & $\begin{array}{r}50 \\
36 \\
26 \\
13 \\
3 \\
1 \\
1\end{array}$ & $\begin{array}{r}55 \\
38 \\
22 \\
5 \\
5 \\
1 \\
1\end{array}$ \\
\hline $\begin{array}{l}\text { Color: } \\
\text { Yeliowish- } \\
\text { Pink } \\
\text { Tan, brownish } \\
\text { Iight- } \\
\text { Clear } \\
\text { Bright olor is not important } \\
\text { Other characteristics }\end{array}$ & $\begin{array}{r}30 \\
24 \\
19 \\
17 \\
9 \\
7 \\
3 \\
1\end{array}$ & $\begin{array}{r}46 \\
5 \\
7 \\
31 \\
11 \\
3 \\
4 \\
1\end{array}$ \\
\hline Number of cases-a & 795 & 624 \\
\hline
\end{tabular}

1 See footnote 1 to table 60 .

2 Percentages add to more than 100 because some respondents mentioned more than one characteristic. 


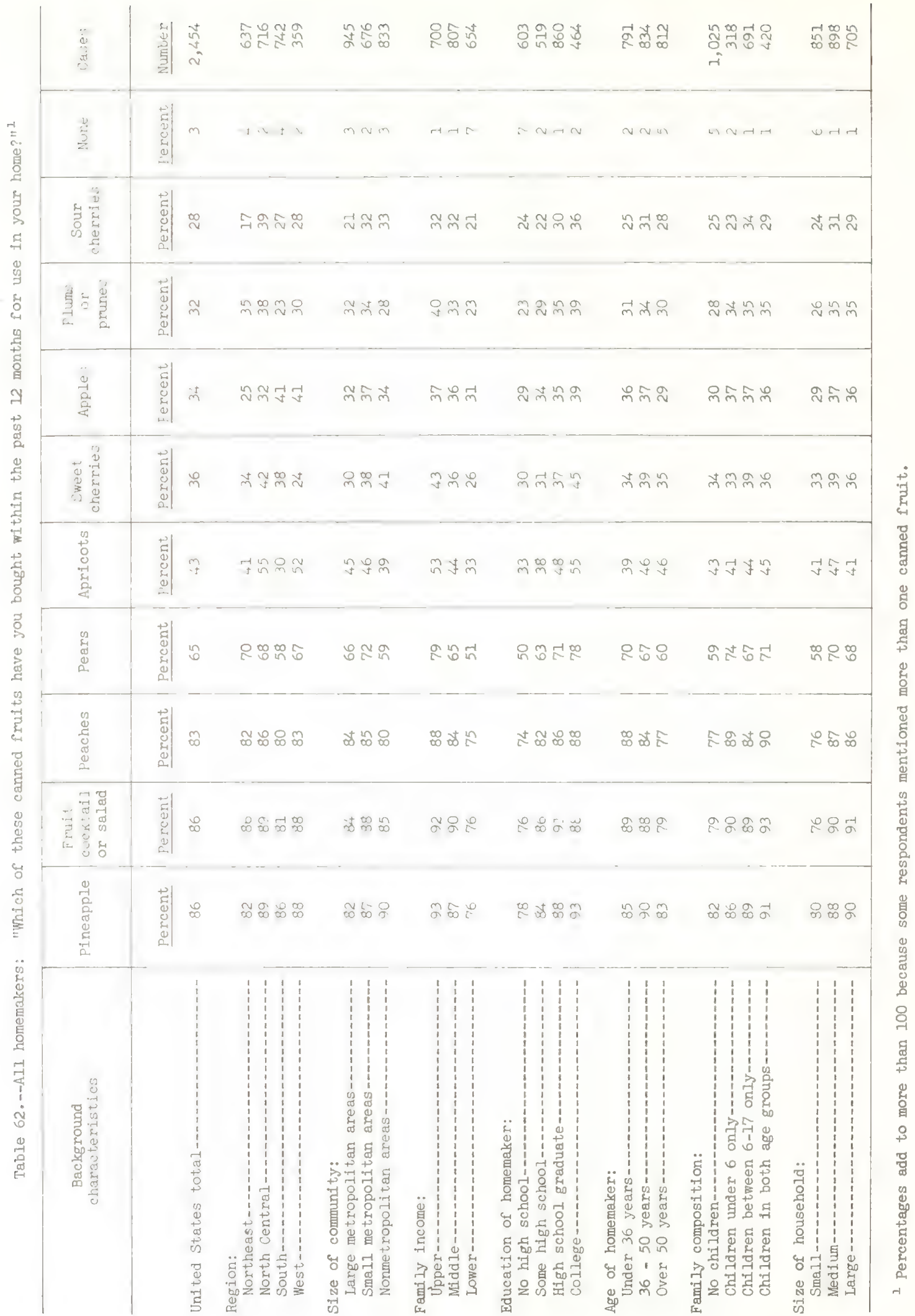




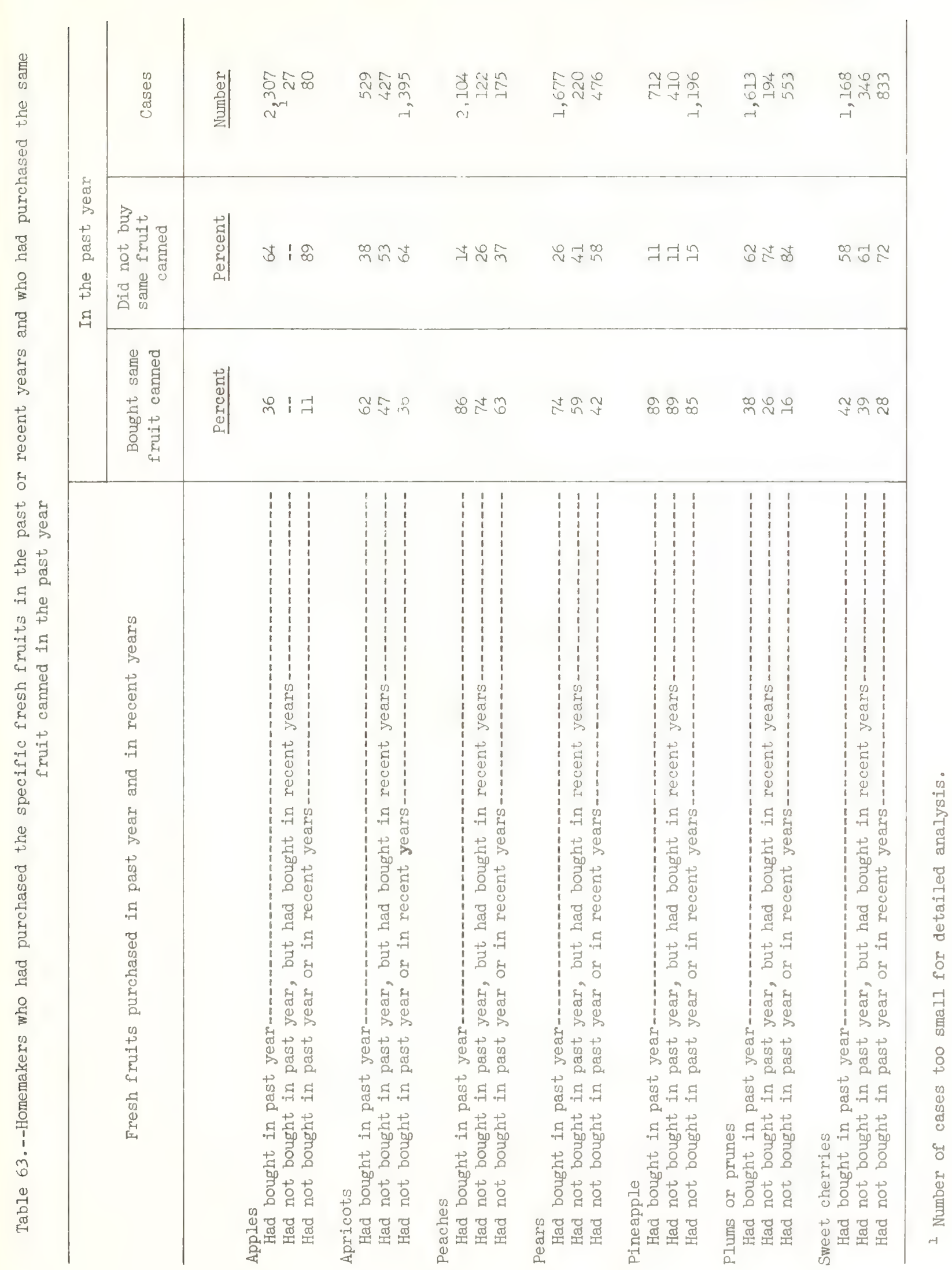




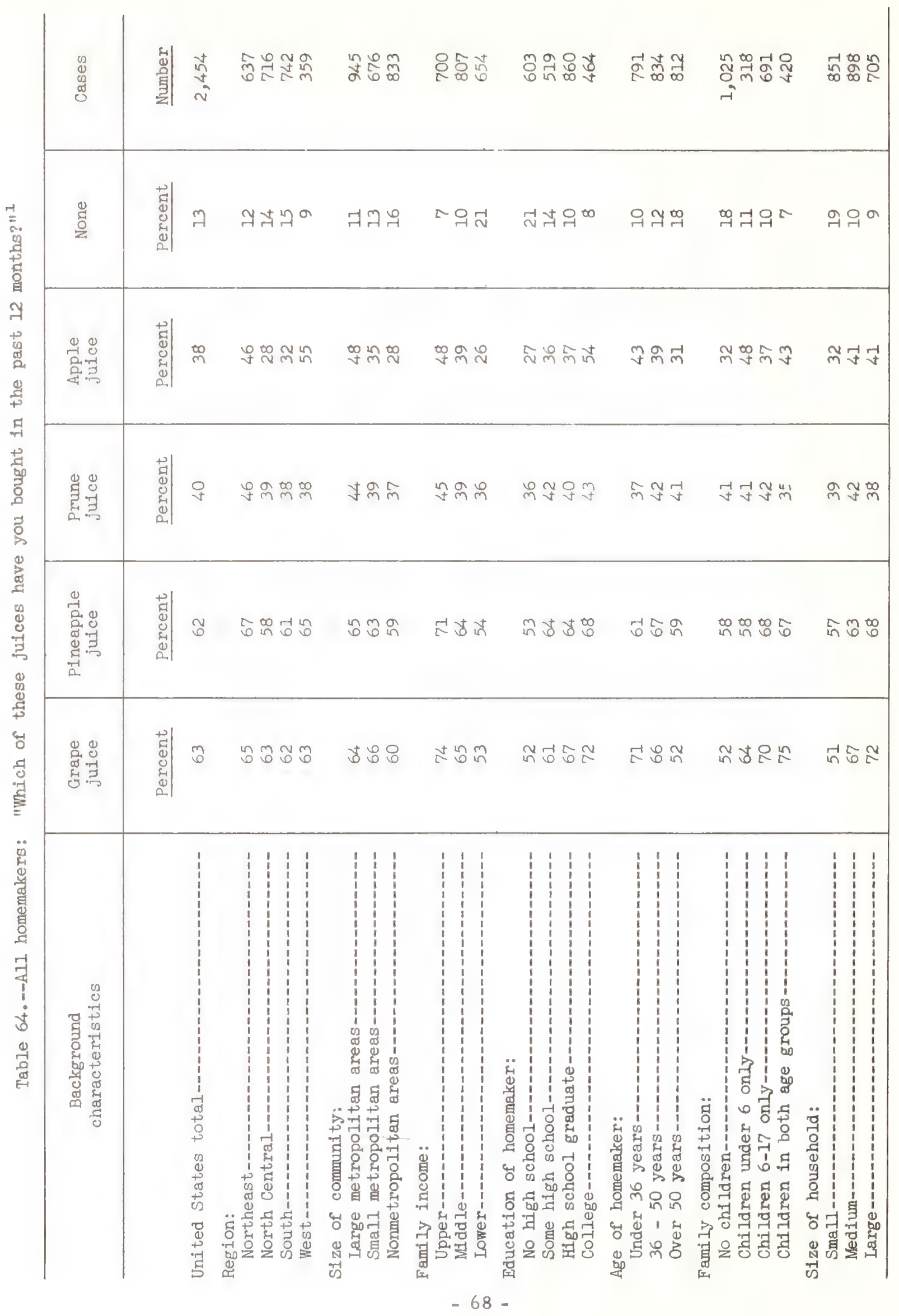

$\stackrel{0}{0}$

ป

急

\&

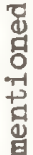

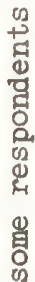

8

్ㅗㅀ

\&્山

$\stackrel{\circ}{+}$

"马्

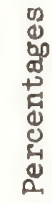


Table 67.--All homemakers: Incidence of purchasing dried prunes, canned plums or prunes, and prune juice in the past year

\begin{tabular}{|c|c|}
\hline Type of prune product purchased & $\begin{array}{c}\text { United States } \\
\text { total }\end{array}$ \\
\hline & Percent \\
\hline 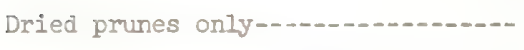 & 21 \\
\hline Canned prunes only-... & 5 \\
\hline 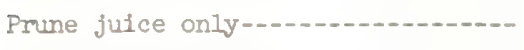 & 7 \\
\hline 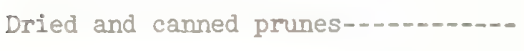 & 9 \\
\hline Dried prunes and prune juice-..... & 15 \\
\hline Canned prunes and prune juice...... & 5 \\
\hline Dried, canned, and prune juice-..-- & 13 \\
\hline Do not buy $\ldots \ldots \ldots$ & 25 \\
\hline 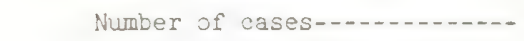 & 2,454 \\
\hline
\end{tabular}

Table 68.--Homemakers who had bought dried pmunes in the past 12 months: "What are your main reasons for buying aried prunes?"1

\begin{tabular}{|c|c|}
\hline Reasons & $\begin{array}{c}\text { United States } \\
\text { total }\end{array}$ \\
\hline & Percent \\
\hline They act as a laxative & 44 \\
\hline To make stewed prunes................... & 19 \\
\hline To use as a breakfast fruit........ & 16 \\
\hline Good for health & 13 \\
\hline To use for recipes & 12 \\
\hline 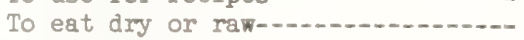 & 12 \\
\hline 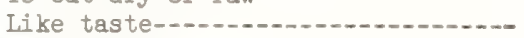 & 10 \\
\hline For variety-......... & 10 \\
\hline 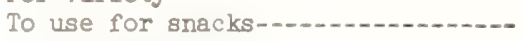 & 9 \\
\hline 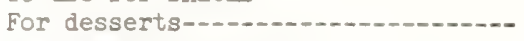 & 7 \\
\hline They are nutritious & 5 \\
\hline Like them (general) & 4 \\
\hline 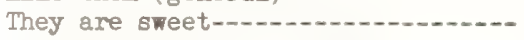 & 4 \\
\hline Good for children's health-........ & 3 \\
\hline To eat as a substitute for sweets-- & 3 \\
\hline They don't spoil & 3 \\
\hline Easy to prepare-..... & 2 \\
\hline 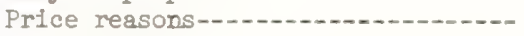 & 2 \\
\hline Habit_-n-nen & 2 \\
\hline For juice-n-n & 2 \\
\hline Other taste reasons & 2 \\
\hline 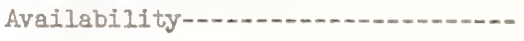 & 1 \\
\hline Not ascertained- & 1 \\
\hline 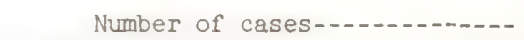 & 1,440 \\
\hline
\end{tabular}

1 Percentages add to more than 100 because some respondents mentioned more than one reason.

Table 69.--Hamemakers who had bought dried prunes in the past 12 months: "What, if anything, don't you like so well about them?"1

\begin{tabular}{|c|c|}
\hline Replies & $\begin{array}{c}\text { United States } \\
\text { total }\end{array}$ \\
\hline & Percent \\
\hline HAVE NO DISLIKES- & 88 \\
\hline HAVE SOME DISLIKES- & 12 \\
\hline They are expensive-................... & 3 \\
\hline 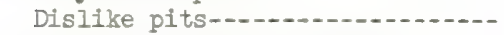 & 3 \\
\hline Dislike preparing them-......- & 2 \\
\hline Dislike the taste-................. & 2 \\
\hline 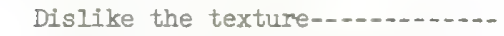 & 1 \\
\hline Dislike for health reasons-....-- & 1 \\
\hline 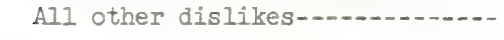 & 2 \\
\hline 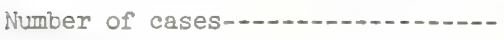 & 1,440 \\
\hline
\end{tabular}

1 Percentages add to more than their group total because some respondents gave more than 1 dislike. 


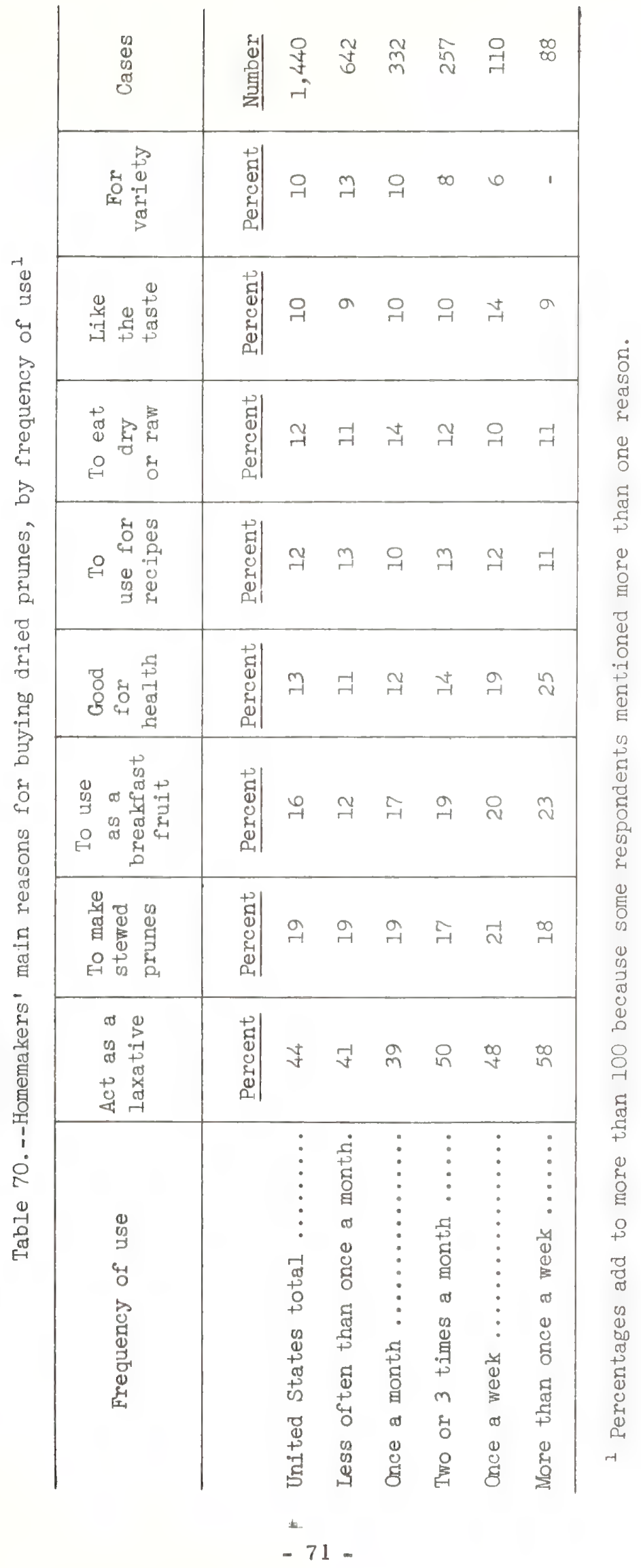


Table 71.--Homemakers who had not purchased dried prunes in the past 12 months: "How come you don't buy dried prunes?" 1

Reasons

United

States

total

Percent

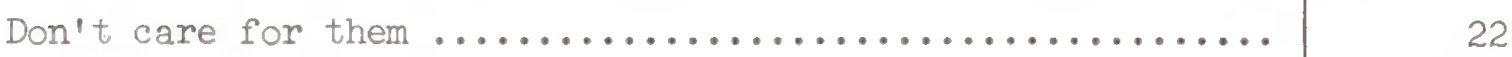

Dislike taste $\ldots \ldots \ldots \ldots \ldots \ldots \ldots \ldots \ldots \ldots \ldots \ldots \ldots \ldots \ldots \ldots \ldots$

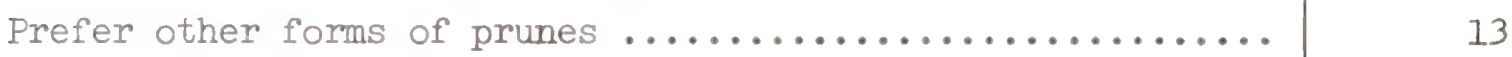

Just don't bother to buy them ..................... 12

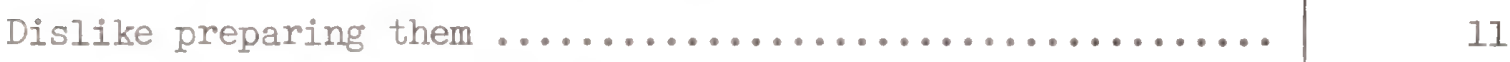

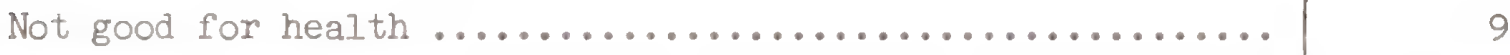

Prefer other fruits $\ldots \ldots \ldots \ldots \ldots \ldots \ldots \ldots \ldots \ldots \ldots \ldots \ldots \ldots \ldots$

Expensive $\ldots \ldots \ldots \ldots \ldots \ldots \ldots \ldots \ldots \ldots \ldots \ldots \ldots \ldots \ldots \ldots \ldots \ldots \ldots \ldots$

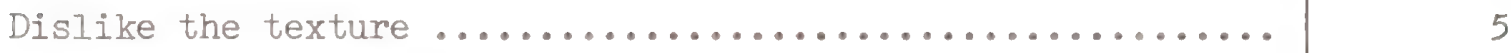

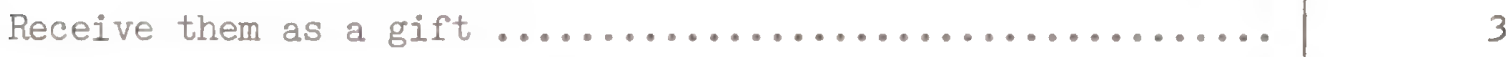

Don't know what they are $\ldots \ldots \ldots \ldots \ldots \ldots \ldots \ldots \ldots \ldots \ldots \ldots \ldots \ldots$

Dislike appearance ............................ 2

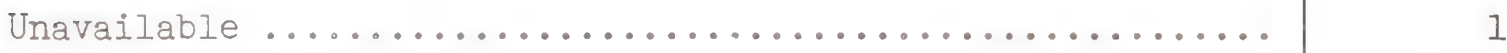

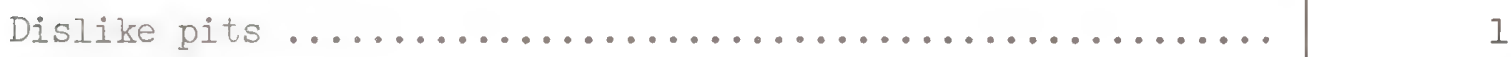

All other reasons $\ldots \ldots \ldots \ldots \ldots \ldots \ldots \ldots \ldots \ldots \ldots \ldots \ldots \ldots \ldots \ldots$

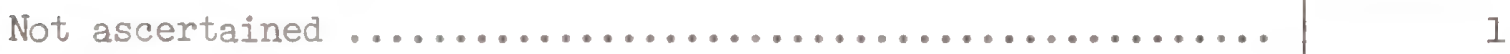

Number of cases .................................................. 14

1 Percentages add to more than 100 because some respondents mentioned more than one reason. 
Table 72.--All homemakers: "Have you used raisins in your home in the last year?" If yes: "About how often have you used raisins in the past year?"

\begin{tabular}{|c|c|c|c|c|c|c|c|c|c|}
\hline \multirow[b]{2}{*}{$\begin{array}{l}\text { Buckground } \\
\text { characteristics }\end{array}$} & \multicolumn{2}{|c|}{$\begin{array}{l}\text { Homemakers } \\
\text { who had-- }\end{array}$} & \multicolumn{7}{|c|}{ Frequency of serving among users } \\
\hline & $\begin{array}{l}\text { Üsed } \\
\text { raisins } \\
\text { in the } \\
\text { past } \\
\text { year }\end{array}$ & $\begin{array}{l}\text { Not used } \\
\text { raisins } \\
\text { in the } \\
\text { past } \\
\text { year }\end{array}$ & Cases & $\begin{array}{l}\text { More } \\
\text { than } \\
\text { once a } \\
\text { week }\end{array}$ & $\begin{array}{l}\text { Once } \\
\text { a } \\
\text { week }\end{array}$ & $\begin{array}{l}2 \text { or } 3 \\
\text { times a } \\
\text { month }\end{array}$ & $\begin{array}{l}\text { Once } \\
\text { a } \\
\text { month }\end{array}$ & $\begin{array}{l}\text { Less } \\
\text { than } \\
\text { once a } \\
\text { month }\end{array}$ & Cases \\
\hline & Percent & Percent & Number & Percent & Percent & Percent & Percent & Percent & Number \\
\hline $\begin{array}{l}\text { United States total } \\
\text { Region: }\end{array}$ & 83 & 17 & 2,454 & 8 & 12 & 20 & 23 & 37 & 2,040 \\
\hline Northeast_- & 79 & 21 & 637 & 9 & 11 & 22 & 21 & 37 & 505 \\
\hline North Central-.......- & 85 & 15 & 716 & 7 & 12 & 20 & 24 & 37 & 607 \\
\hline 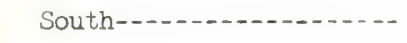 & 83 & 17 & 742 & 5 & 10 & 19 & 23 & 43 & 618 \\
\hline Wamily composition: & 86 & 14 & 359 & 15 & 17 & 19 & 22 & 27 & 310 \\
\hline No children-..........- & 75 & 25 & 1,025 & 6 & 11 & 20 & 22 & 41 & 765 \\
\hline Children under 6 only--- & 83 & 17 & 318 & 9 & 12 & 20 & 20 & 39 & 264 \\
\hline Children 6-17 only-n-... & 89 & 11 & 691 & 9 & 12 & 20 & 22 & 37 & 618 \\
\hline $\begin{array}{l}\text { Children in both age } \\
\text { groups }\end{array}$ & 94 & 6 & 420 & 10 & 15 & 20 & 26 & 29 & 393 \\
\hline
\end{tabular}




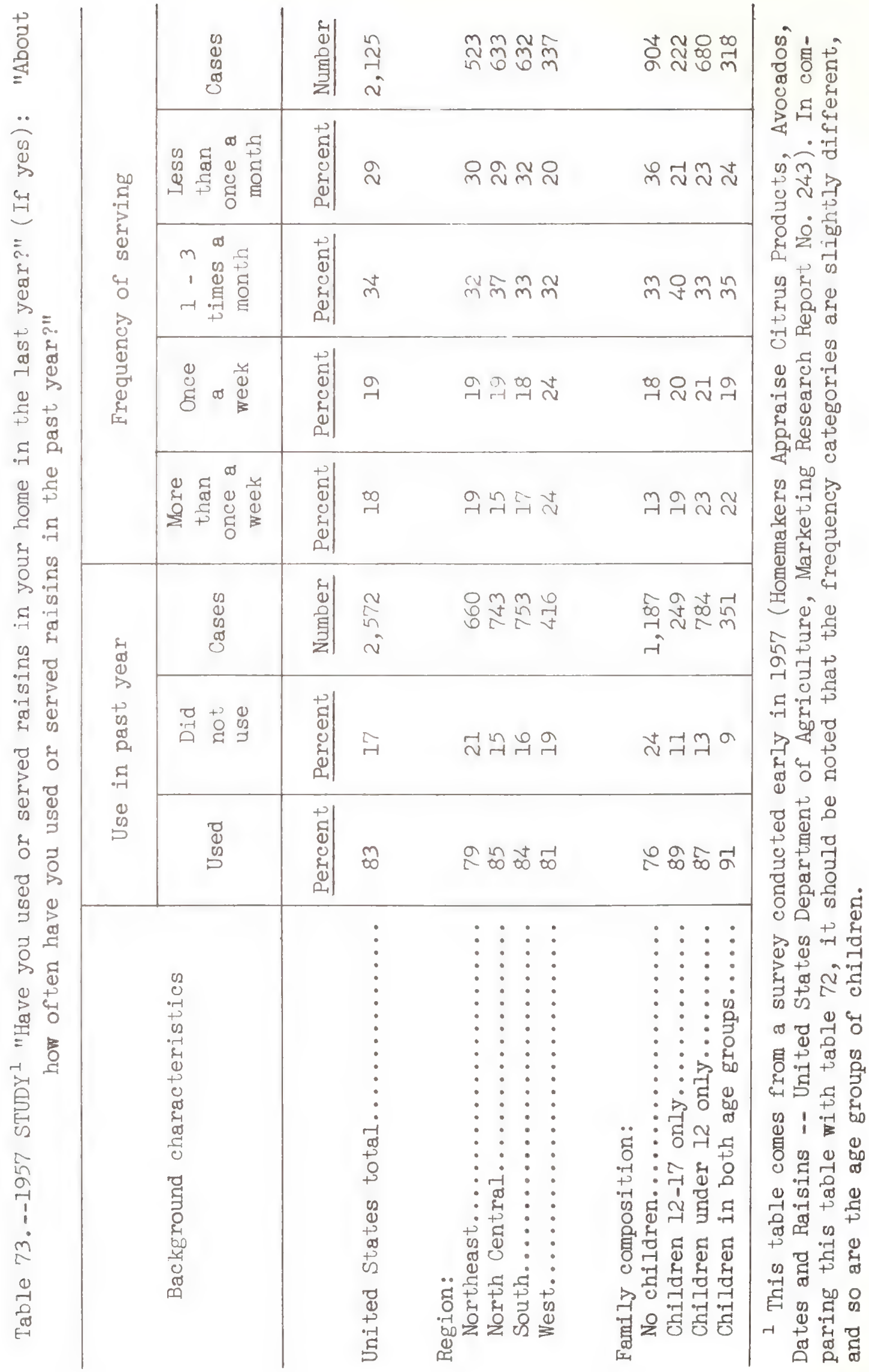


With the exception of check-box material, some instructions to interviewers, office record information, and free-answer space, the questionnaire used for this study is reproduced below in entirety. Instructions to interviewers are in upper case letters enclosed in parentheses.

Good morning/afternoon/evening. I am of Crossley, S-D Surveys, an independent marketing research firm. We are conducting a survey for the U.S. Department of Agriculture talking to homemakers about the fresh fruits that they buy.

1a. (SHOW RESPONDENT'S CARD A) Which of these fresh fruits have you or your family bought in the past 12 months? b. (FOR EACH FRESH FRUIT NOT BOUGHT) Why haven't you bought fresh (FRUIT) in the past year? c. (FOR EACH FRESH FRUIT NOT BOUGHT) Have you bought fresh (FRUIT) in recent years?

RESPONDENT'S CARD A

$\begin{array}{lll}\text { Apples } & \text { Grapes } & \text { Pears } \\ \text { Apricots } & \text { Nectarines } & \text { Pineapples } \\ \text { Barianas } & \text { Oranges } & \text { Plums or fresh } \\ \text { Cherries } & \text { Peaches } & \text { prunes }\end{array}$

d. (IF NONE OF THESE FRESH FRUITS HAVE BEEN BOUGHT IN THE PAST YEAR) Why is that?

(FOR HOMEMAKERS WHO HAD BOUGHT NONE OF THESE FRESH FRUITS, SKIP TO QUESTION 24a)

2a. (FOR EACH OF THESE FRESH FRUITS--APPLES, BANANAS, GRAPES, PEACHES) Would you say the amount of (FRUIT) you have bought in the past 12 months is more, less, or about the same as the amount bought, say, 5 years ago? b. (IF "MORE" OR "LESS") Why are you buying more/less (FRUIT) now?

3a. (FOR EACH OF THESE FRESH FRUITS--APPLES, BANANAS, GRAPES, PEACHES, PEARS, PLUMS OR FRESH PRUNES) During which season of the year do you buy the greatest amount of fresh (FRUIT)? $b$. What amount of fresh (FRUIT) do you usually buy at a time during (THAT SEASON)? c. About how often do you buy (FRUIT) in this quantity during (THAT SEASON)? d. In what other seasons do you buy fresh (FRUIT)?

4. Suppose you were the manager of a store and wanted to get people to buy more of these fresh fruits. What ways can you think of that might get your customers to buy more?

5a. What kind of fresh fruit did you buy last? b. (FOR EACH KIND OF FRESH FRUIT BOUGHT) Did you buy (FRUIT) loose or already in some kind of bag or container? c. (FOR EACH KIND OF FRESH FRUIT BOUGHT) Which one of these statements comes closest to describing how you decided to buy (FRUIT)--

$$
\begin{aligned}
& \text { Planned to buy this fruit before entering the store? } \\
& \text { Planned to buy some kind of fruit, but decided on } \\
& \text { this kind in the store? } \\
& \text { Didn't plan to buy fruit ahead of time, decided to } \\
& \text { buy this kind in the store? }
\end{aligned}
$$

6a. In general, would you like to buy fresh fruit that is already in some kind of bag or container, or would you rather buy it loose? b. (WHETHER PACKAGED OR LOOSE FRUIT IS PREFERRED) Are there any fresh fruits you don't like to buy this way? c. (IF THERE ARE FRESH FRUITS NOT LIKED IN THE WAY GENERALLY PREFERRED) Which ones?

7a. What are the advantages of buying fresh fruit loose? b. What are the advantages of buying fresh fruit in some kind of bag or container?

8. (SHOW RESPONDENT'S CARD B AND ASK FOR EACH OF THESE FRESH FRUITS--APPLES, BANANAS, GRAPES, PEACHES, PEARS, PLUMS OR FRESH PRUNES) Here's a list of statements which some people have made about fresh fruits. Which of these statements do you feel are especially true about (FRUIT)?

9. (SHOW RESPONDENT'S CARD B) How would you rate the importance of each of these factors when you are considering which fresh fruits to purchase? For example would you say "Can be used many ways" is very important, fairly important, or not too important to you? 
RESPONDENT'S CARD B

Can be used many ways

Difficult to tell when ripe

Family does not like them

Reasonably priced when in season

Often bruised, blemished

Hard to digest

Good laxative

Low in calories

Spoils easily

\author{
Messy to eat \\ Can buy ready to use without \\ further ripening \\ Good for health \\ Hard to find variety liked even \\ in season \\ Hard to find good quality even \\ in season \\ Good for snacks/packed lunches
}

(IF HOMEMAKER HAS PURCHASED FRESH APPLES IN THE PAST 12 MONTHS--SEE QUESTION 1a--ASK THE FOLLOWING QUESTIONS. IF NOT, SKIP TO QUESTION 23)

\section{Fresh Apple Section}

Now we would like to know a little more about your use of fresh apples.

10a. Where do you buy fresh apples most often to use at home? b. Where else do you buy them occasional1y?

11a. During the fall and winter do you use fresh apples at least once a week or do you use them less often? $b$. What about the spring? $c$. What about the sumer? d. (FOR EACH SEASON IN WHICH APPLES ARE USED LESS OFTEN THAN ONCE A WEEK) Why don't you use them more often during (SEASON)?

12a. During the past year, in which of these ways have you used raw apples in your home? Eaten out-ofhand? Salads? Fruit cups? b. (IF RAW APPLES NOT USED) How come you haven't used any raw apples?

13a. (IF RAW APPLES USED) When are apples eaten raw most often by your family? Meals at home? Packed lunches? Daytime snacks? Evening snacks? b. When else are they eaten in this way? Meals at home? Packed lunches? Daytime snacks? Evening snacks?

14a. (SHOW RESPONDENT'S CARD C) Which of these qualities do you look for when choosing fresh apples for eating raw? b. Which variety or kind of apples do you prefer for eating raw?

\section{RESPONDENT'S CARD C}

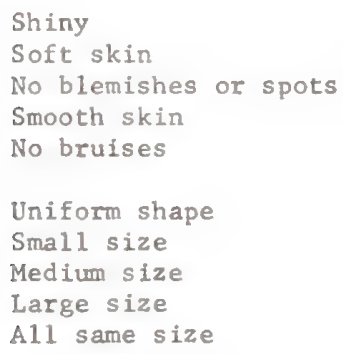

Deep red
Bright red
Part red, part green
Green
Yellow
Hard
Soft
Firm, but not hard
Sweet
Tart

Dry
Juicy
Variety or kind of apple

15. During the past year have you used fresh apples for cooking or baking?

16a. (SHOW RESPONDENT'S CARD C IF FRESH APPLES USED FOR COOKING OR BAKING DURING THE PAST YEAR) WhICh Of these qualities do you look for when choosing fresh apples for cooking or baking? b. Which variety or kind of apples do you prefer for cooking or baking?

\section{RESPONDENT'S CARD $\mathrm{C}$}

\section{SAME AS CARD SHOWN IN QUESTION $14 a$}

17. (IF FRESH APPLES NOT USED FOR COOKING OR BAKING--SEE QUESTION 15) How come you haven't used fresh apples for cooking or baking? 
(IF HOMEMAKER HAS USED FRESH APPLES FOR COOKING OR BAKING IN THE PAST YEAR--SEE QUESTION 15--ASK THE FOLLOWING QUESTIONS. IF NOT, SKIP TO QUESTION 20a)

18a. During the past year, in which of these ways have you used fresh apples for cooking or baking? Homemade applesauce? Baked apples? Apple cake? Apple pie? Other dessert? Some other way? b. 1hat percentage of all the fresh apples bought during the past year did you use for cooking or baking?

19a. Do you sometimes buy a certain variety or kind of apple especially for cooking or baking? b. (IF HOMEMAKER DOES NOT BUY A CERTAIN VARIETY FOR BAKING OR COOKING) Why not?

(ASK EVERYONE WHO HAS BOUGHT FRESH APPLES IN THE PAST YEAR)

20a. Do you have any difficulty in finding good fresh apples for cooking or eating raw? b. (IF HOMEMAKER HAD DIFFICULTY) Is that at any particular time of year? c. (IF HOMEMAKER HAD DIFFICULTY AT ANY PARTICULAR TIME OF YEAR) At what particular time of year does this occur? d. (IF HOMEMAKER HAD DIFFICULTY) Is this with any special variety or kind of apple? e. (IF HOMEMAKER HAD DLFFICULTY WITH ANY SPECIAL VARIETY OR KIND OF APPLE) With what particular variety or kind of apples does this occur?

21a. Have you been disappointed in apples that you have bought during the past year? b. (IF DISAPPOINTED) In what ways? c. (IF DISAPPOINTED) Where did you buy the apples you did not like?

22a. Have you bought something else at any time in the past year when you would have preferred to buy apples? b. (IF SOMETHING ELSE BOUGHT) What did you buy (LAST TIME)? C. (IF SOMETHING ELSE BOUGHT) What were the circumstances?

23. (IF AT LEAST ONE FRESH FRUIT HAS BEEN BOUGHT IN THE PAST YEAR--SEE QUESTION Ia) Is there anything you don't like so well about using fresh apples? Apricots? Cherries? Grapes? Nectarines? Peaches? Pears? Pineapple? Plums or fresh prunes?

\section{Processed Fruits and Juices Section}

24a. Which of these canned fruits have you bought within the past 12 months for use in your home? Apples? Apricots? Peaches? Pears? Sweet cherries? Sour cherries? Plums or prunes? Fruit cocktail or salad? Pineapple? $b$. Which of these juices have you bought in the past 12 months? Apple? Grape? Pineapple? Prune?

25a. Have you bought any dried prunes in the past 12 months? b. (IF DRIED PRUNES NOT BOUGHT) How come you don't buy dried prunes? c. (IF DRIED PRUNES BOUGHT) What are your main reasons for buying dried prunes? d. (IF DRIED PRUNES BOUGHT) What, if anything, don't you like so well about them? e. (IF DRIED PRUNES BOUGHT) How often have you used them in the past year?

26a. Have you used raisins in your home in the last year? b. (IF RAISINS USED) About how often have you used raisins in the last year?

27a. Have you bought any applesauce in cans or jars in the past 12 months? b. (IF APPLESAUCE BOUGHT) How do you generally use the applesauce you buy?

28a. (IF APPLESAUCE BOUGHT) Which do you prefer, homemade applesauce or the kind you can buy in the store? b. (IF EITHER TYPE IS PREFERRED) Why is that?

29a. How would you describe the way good applesauce should look and taste? b. (IF "COLOR" NOT MENTIONED) What about color? c. (IF "CONSISTENCY" NOT MENTIONED) What about consistency?

\section{CLASS IFICATION DATA}

30a. How many members including yourself, are there living in this household? b. How many of them are:

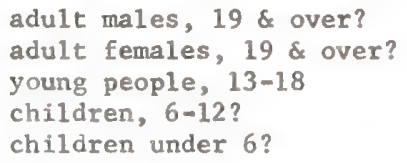

31. What was the last grade you completed at schoo1?

32. Are you married or single?

33. What was your age on your last birthday? 
34a. What is the occupation of the head of the household? does he/she work?

35a. What is your occupation? b. (IF EMPLOYED) In what type of business or industry do you work? c. (IF EMPLOYED) Are you employed part time/full time?

36. (SHOW INCONE CARD) Into which of these groupings does your combined family income from all sources of all those in your immediate household fall? (Please include income from salaries, investments, dividends, net income from farming or self-employment, rent, royalties, capital gains from sales, bonuses, comissions, etc.)

$$
\begin{aligned}
& \text { RESPONDENT'S CARD D } \\
& \text { Under } \$ 2,000 \\
& \$ 2,000 \text { to } \$ 2,999 \\
& \$ 3,000 \text { to } \$ 3,999 \\
& \$ 4,000 \text { to } \$ 4,999 \\
& \$ 5,000 \text { to } \$ 5,999 \\
& \$ 6,000 \text { to } \$ 6,999 \\
& \$ 7,000 \text { to } \$ 7,999 \\
& \$ 8,000 \text { to } \$ 8,999 \\
& \$ 9,000 \text { to } \$ 10,999 \\
& \$ 11,000 \text { to } \$ 14,999 \\
& \$ 15,000 \text { or over }
\end{aligned}
$$

37. Sex of respondent. 


